Life Sciences Contribution

Royal Ontario Museum

80

A Systematic Review of the Nearctic and Neotropical River Otters (Genus Lutra, Mustelidae, Carnivora)

C. G. van Zyll de Jong

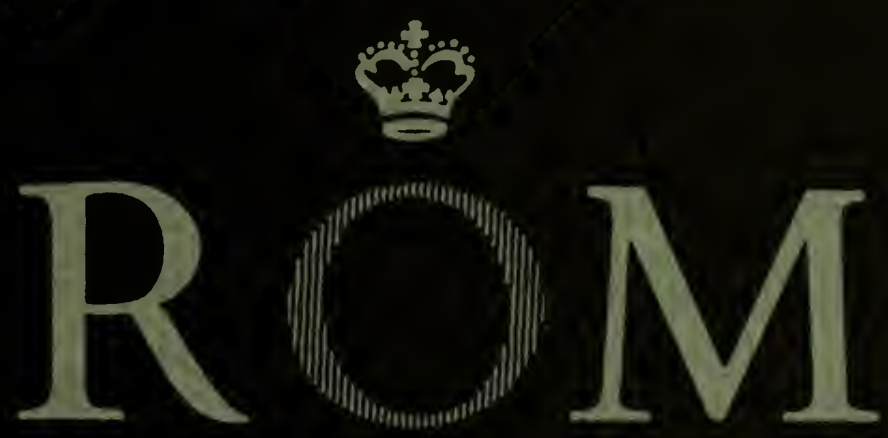




\section{DEPARTMENT COPY}


LIFE SCIENCES CONTRIBUTIONS

ROYAL ONTARIO MUSEUM

NUMBER 80

C. G. van zyll de jong A Systematic Review of the Nearctic and Neotropical River Otters (Genus Lutra, Mustelidae, Carnivora) 


\section{ROYAL ONTARIO MUSEUM \\ PUBLICATIONS IN LIFE SCIENCES}

The Royal Ontario Museum publishes three series in the Life Sciences:

LIFE SCIENCES CONTRIBUTIONS, a numbered series of original scientific publications, including monographic works.

LIFE SCIENCES OCCASIONAL PAPERS, a numbered series of original scientific publications, primarily short and usually of taxonomic significance.

I.IFE SCIENCES MISCELLANEOUS PUBLICATIONS, an unnumbered series of publications of varied subject matter and format.

All manuscripts considered for publication are subject to the scrutiny and editorial policies of the Life Sciences Editorial Board, and to review by persons outside the Museum staff who are authorities in the particular field involved.

LIFE SCIENCES EDITORIAL BOARD, 1970-1971

Chairman: P. C. SWANN

Director, Royal Ontario Museum

Editors: E. J. CROSSMAN

J. R. TAMSITT

C. G. VAN ZYLL DE JONG is Chief of Wildlife Research, Research Branch, Manitoba Department of Mines and Natural Resources. This publication is based on research by the author carried out in the Department of Mammalogy, Royal Ontario Museum, for which he was awarded a doctorate at the University of Toronto, Department of Zoology.

The publication of Contribution No. 80 was generously supported by a grantin-aid of research from the Canadian National Sportsmen's Show to Dr. R. L. Peterson, Curator, Department of Mammalogy, Royal Ontario Museum.

PRICE: $\$ 5.00$

(C)The Royal Ontario Museum, 1972

100 Queen's Park, Toronto, Canada

PRINTED AT THE BRYANT PRESS LIMITED 


\section{Contents}

Abstract, 1

Introduction, 2

Materials and Methods, 4

Materials and subdivision of samples, 4

Methods of analysis, 7

System of mensuration, 10

Results and Discussion, 12

Geographic variation in size, 12

Sexual dimorphism, 16

Allometric analysis, 19

Other characters, 31

Overall similarity, 50

The Fossil Record, 69

General review, 70

Fossil forms of the American group of river otters, 74

Summary, 80

Key to the genera of the subfamily Lutrinae, 82

Key to the species of the genus Lontra, 83

Synopses, 84

Acknowledgments, 89

Literature Cited, 91

Appendix 1 - Specimens examined, 97

Appendix 2 - Characters used in the calculation of the taxonomic distance, 101

Appendix 3-Selected skull and tooth measurement, 101-104 
Digitized by the Internet Archive in 2011 with funding from University of Toronto 


\title{
A Systematic Review of the Nearctic and Neotropical River Otters (Genus Lutra, Mustelidae, Carnivora)
}

\begin{abstract}
The river otters of the Western Hemisphere were recognized as a distinct group of related species within the genus Lutra by Pohle (1920) in his revision of the Lutrinae. Since then a need has remained for further clarification of the relationships within the group, as well as that of the group as a whole to other forms in the subfamily. A large number of specimens was compared in an attempt to determine these relationships. Materials consisted largely of skulls, but also used were skins and postcranial material, available in smaller numbers. A number of bivariate relationships of the skull and dentition were analyzed allometrically and the overall similarities of nearly all species of Lutrinae were estimated using taxonomic distance.
\end{abstract}

Other qualitative and descriptive comparisons were made to complement these methods. The amount of morphological variation within known wide-ranging species and between valid sympatric species were criteria used to infer the specific status of the taxa that were compared. Results of these comparisons led me to conclude that there are probably four Recent species of river otter in the Western Hemisphere, corresponding to the North American Lutra canadensis, the Neotropical L. annectens-enudris-platensis group, the Chilean $L$. provocax and the southern Pacific coastal form $L$. felina. The latter is the most distinct species and probably represents the earliest invader of the relatively isolated Chilean faunal province. Another Chilean species, L. provocax, is more similar to the other large Neotropical forms. Evidence further suggests that the relationship of the American river otters with L. lutra and other Old World species of that genus is not as close as was formerly assumed. Aside from differences in skull and dentition, the marked differences in the known bacula may be regarded as significant evidence of their distinctness. The analysis of overall similarity suggests that Pohle's platensis group merits generic rank. Infraspecific variation was analyzed, but not in Neotropical species because of insufficient geographical representation in samples. I propose that the platensis group of Pohle be elevated to generic rank, for which the name Lontra Gray 1843 is available, and that $L$. annectens, L. enudris and L. platensis represent one species, which should bear the name Lontra longicaudis Olfers 1818. 


\section{Introduction}

The subfamily Lutrinae represents a small, well-defined group within the Mustelidae. Despite its manageable size and the attention it has received from a number of mammalogists, including Pohle (1920), whose work is an outstanding contribution to the study of the group, there still remains much to be learned. The confused taxonomic state and almost complete lack of information regarding the biology of the African otters Aonyx and Paraonyx, the inadequate knowledge of the taxonomy, distribution and ecology of the otters of Southeast Asia and the relationships within the American river otters rank foremost among the problems in need of solution. This study attempts to elucidate relationships of the American river otters of the genus Lutra.

The Lutrinae are represented in the Recent fauna of the Western Hemisphere by three genera: Lutra, Pteronura and Enhydra. Of these, the genus Lutra, which includes a number of described species, occurs from near the northern limits of continental North America to the extreme south of South America. The genera Pteronura and Enhydra, both monotypic, occupy restricted ranges in South America and along the Pacific coast of North America and northeast Asia respectively.

The genus Lutra Brünnich has included, at one time or another, most living species of Lutrinae. In his revision of the subfamily Pohle (1920) restricted the genus to the small and medium sized, predominantly ichthyophagous species possessing a largely trenchant dentition. This usage has been generally accepted, although the Asiatic smooth-coated otter and the African spotted-necked otter are often placed in the genera Lutrogale (Pocock, 1940; Simpson, 1945) and Hydrictis (Pocock, 1921). The genus Lutra according to Pohle is subdivided into two subgenera, Lutra and Lutrogale. The first is again divided into four groups; the sumatrana, maculicollis, lutra and platensis groups. Pohle recognized 15 species; one in the subgenus Lutrogale and 14 in the subgenus Lutra, three of which are in the sumatrana, three in the maculicollis, two in the lutra and six in the platensis group. At present Pohle's groups, with the sole exception of the platensis group, are generally considered to consist of a single species each (Allen, 1939; Chasen, 1940; Ellerman and Morrison-Scott, 1951).

The platensis group, which is the primary concern of this study, was first created by Thomas (1908) for the Neotropical forms $L$. annectens, L. emerita, L. provocax, L. platensis, L. incarum, L. mitis and L. enudris, a group to which L. parilina was later added (Thomas, 1914). Pohle (1920) retained the group in his revision and included the North American L. canadensis and the South American L. felina because of the fundamental structural similarity of the skull and dentition. He further reduced four species recognized by Thomas $(1908,1914)$ to subspecies (L. annectens emerita, L. a. parilina, L. enudris incarum and L. e. mitis). Cabrera (1957), in his check list of South American mammals, recognized six species ( $L$. annectens, L. enudris, L. felina, L. incarum, L. platensis and L. provocax). In a recent book Harris (1968) listed eight species for the 
Americas, one Nearctic species (L. canadensis) and seven Neotropical species, which are the same as those listed by Cabrera (1957) in addition to L. mesopetes. Harris' work provided a useful summary of the literature but added no new information on the systematics of the group.

A comment on the taxonomic status of $L$. mesopetes is needed here. The taxon is based on a single specimen from Costa Rica (Cabrera, 1924). No specimens like it have been collected from that area since, nor did Goodwin (1946) mention it in his monograph on the mammals of Costa Rica. The original description does not give sufficient information to determine the holotype's identity and I was not able to examine the type specimen. Only a re-examination and comparison of the type specimen with other taxa can elucidate its taxonomic relationships.

L. canadensis is the best known of the American forms, for its taxonomy, distribution and general biology have been relatively well investigated. The Neotropical forms are much less known. There is virtually no information available on their biology or ecology. Many "species" were described from a single specimen or from inadequate samples during a period when the typological species concept still exerted a dominant influence on taxonomic theory and practice; at the time there was insufficient awareness of variation in populations and its underlying mechanisms. The same is true of the many subspecies described in L. canadensis.

In view of the history outlined above a re-examination of the platensis group, based on adequate material, is needed to interpret results in the light of modern concepts and theories. The major goals of this study were to answer the following questions:

(a) What are the relationships of the various forms within the platensis group?

(b) What is the relationship of the platensis group to other members of the genus Lutra?

(c) How can these relationships best be translated into formal classification?

The evidence for the solution of these questions was derived mainly from cranial and dental morphology, as the material was most readily available. Other evidence was used where possible. Pohle's (1920) classification of the American otters, being the most recent and comprehensive, was the starting point for this study. The work of Hall and Kelson (1959) served that function for the subspecific classification of $L$. canadensis as it gives the most up-to-date summary of the subspecies. 


\section{Materials and Methods}

\section{Materials and the Subdivision of Samples}

Specimens studied consisted chiefly of skulls (897) and, to a lesser extent, of postcranial skeletal parts and skins. Most material represented American species of Lutra, but also included were smaller samples of other representatives of the subfamily. Data obtained from 696 specimens from the New World were supplemented by measurements taken from the tables of Pohle (1920). Specimens examined (see Appendix 1) are in the collections of the following institutions: American Museum of Natural History (AMNH), Academy of Natural Sciences of Philadelphia (ANSP), The British Museum (Natural History) (BM), California Academy of Sciences (CAS), Cornell University (CU), Field Museum of Natural History, (FMNH), Institut Royal des Sciences de Belgique (IRSB), Museum of Comparative Zoology, Harvard University (MCZ), Memorial University (MEMU), Muséum National d'Histoire Naturelle, Paris (MNHN), Michigan State University (MSU), Museum of Vertebrate Zoology, University of California (MVZ), National Museum of Canada (NMC), Natur-Museum und Forschungs-Institut Senckenberg (NMFIS), Peabody Museum, Yale University (YPM), Provincial Museum of British Columbia (PMBC), Swedish Museum of Natural History, Stockholm (SMNH), United States National Museum (USNM), University of British Columbia (UBC), Museum of Natural History, University of Kansas (UK), Museum of Zoology, University of Michigan (UM), Zoological Museum, Copenhagen (ZM).

The sex, age and number of crania of New World species, including those taken from the above sources, are summarized in Table 1. Data from specimens of other species including Lutra lutra (59), L. sumatrana (10), L. perspicillata (14), L maculicollis (31), Pteronura brasiliensis (13), Amblonyx cinerea (14), Aonyx capensis (9), Paraonyx phillipii (1), and Enhydra lutris (7), as well as from those listed by Pohle (1920) and Ognev (1962), were also used.

Skulls were assigned to relative age classes using criteria proposed by Hooper and Ostenson (1949), who recognized four age groups. Pohle's (1920) groups, also four in number if his "embryonal" category is omitted, are not synonymous with those of Hooper and Ostenson (1949). His first category, "pull.", contains only specimens with deciduous dentition, and his second category, "juv.", probably contains Hooper and Ostenson's groups 1 and 2 . Consequently these two groups were combined for purposes of tabulation; moreover their distinctness was not crucial for the analysis. Pohle's "pull." group was not included in the analysis, as the coefficients of allometry in this group were smaller than those in older age groups when raw data were plotted. Patterns similar to those of otters were also found by Kurtén (1964) in bears.

The distribution of the species and the localities from which specimens originated are shown in Fig. 1. The total sample was subdivided into smaller samples for analyses based on taxa recognized by Pohle (1920) 
TABLE 1 Sex and age of Lutra, including those crania listed by Pohle (1920)

\begin{tabular}{|c|c|c|c|c|c|c|c|c|c|c|}
\hline & \multicolumn{3}{|c|}{ Males } & \multicolumn{3}{|c|}{ Females } & \multicolumn{3}{|c|}{ Unknown } & \multirow[b]{2}{*}{ Total } \\
\hline & $\begin{array}{l}\text { juve- } \\
\text { nile }\end{array}$ & $\begin{array}{l}\text { sub- } \\
\text { adult }\end{array}$ & adult & $\begin{array}{c}\text { juve- } \\
\text { nile }\end{array}$ & $\begin{array}{l}\text { sub- } \\
\text { adult }\end{array}$ & adult & $\begin{array}{c}\text { juve- } \\
\text { nile }\end{array}$ & $\begin{array}{l}\text { sub- } \\
\text { adult }\end{array}$ & adult & \\
\hline L. c. brevipilosus & 3 & 2 & 4 & 4 & 2 & 6 & 1 & 1 & - & 23 \\
\hline L. c. canadensis & 22 & 13 & 26 & 24 & 10 & 12 & 16 & 9 & 13 & 145 \\
\hline L. c. chimo & 5 & 1 & 3 & 2 & 3 & 1 & 6 & 3 & 20 & 44 \\
\hline L. c. degener & 2 & - & 1 & 2 & 1 & 1 & 6 & 2 & 3 & 18 \\
\hline L. c. evexa & 6 & 6 & 10 & 10 & 3 & 9 & 1 & 2 & 3 & 50 \\
\hline L. c.extera & - & - & - & - & - & - & - & - & 1 & 1 \\
\hline L. c. interior & - & - & - & - & 1 & 1 & 1 & 3 & 3 & 9 \\
\hline L. c. kodiacensis & 1 & - & - & - & 1 & 1 & 2 & 1 & 11 & 17 \\
\hline L. c. lataxina & 6 & 一 & 4 & 1 & 一 & 2 & 3 & 3 & 5 & 24 \\
\hline L. c. nexa & - & 2 & 1 & 1 & 2 & 3 & 1 & 2 & 3 & 15 \\
\hline L. c. optiva & 3 & 1 & 2 & 2 & 1 & 1 & 5 & - & 6 & 21 \\
\hline L. c.pacifica & 9 & 4 & 7 & 5 & 4 & 1 & 2 & 1 & 7 & 40 \\
\hline L. c.periclyzomae & - & 1 & 5 & 一 & 3 & 4 & 4 & 1 & 7 & 25 \\
\hline L. c.preblei & 11 & 3 & 5 & 12 & 2 & 6 & 9 & 1 & 9 & 58 \\
\hline L. c. sonora & - & 1 & 1 & - & 一 & 1 & - & - & - & 3 \\
\hline L. c. texensis & 1 & 5 & 6 & - & 1 & 3 & - & 1 & 1 & 18 \\
\hline L. c. yukonensis & 3 & - & 3 & 一 & 2 & - & 5 & 2 & 4 & 19 \\
\hline L. c. vaga & 4 & 6 & 7 & 一 & 3 & 7 & - & 1 & 7 & 35 \\
\hline L. c. vancouverensis & 2 & 2 & 1 & 3 & - & 5 & 3 & - & 2 & 17 \\
\hline L. c. mira & 1 & 1 & 1 & 2 & - & - & - & 2 & 2 & 9 \\
\hline L. a. annectens & 2 & 1 & 4 & 1 & - & 1 & 2 & - & 2 & 13 \\
\hline L. a. latidens & 1 & 2 & 2 & - & 2 & 1 & 1 & 1 & 2 & 12 \\
\hline L. a. repanda & - & 2 & 1 & - & - & 3 & 1 & - & 1 & 8 \\
\hline L. a. ssp. (S. Amer.) & 2 & - & 4 & 1 & 1 & 2 & - & 1 & - & 11 \\
\hline L. enudris & 3 & 5 & 3 & 1 & 2 & 6 & 2 & 4 & 2 & 28 \\
\hline L. platensis & 2 & - & 8 & 1 & 2 & 12 & 11 & 1 & 6 & 43 \\
\hline L. provocax & 1 & - & 2 & 1 & - & 2 & 1 & - & 3 & 10 \\
\hline L. felina & 1 & 1 & 1 & 3 & 1 & 3 & 4 & 3 & 6 & 23 \\
\hline & & & & & & & Total & & & 739 \\
\hline
\end{tabular}

and Hall and Kelson (1959) and on geographical criteria. The delimitation of the ranges of the subspecies and species are often poorly known. Pohle's (1920) map giving the distribution of the species and subspecies of the platensis group contains a number of inaccuracies and moreover the number of subspecies whose distribution must be considered has increased. Hall and Kelson (1959) showed the distribution of subspecies of North American species, but their ranges are only rough approximations. Subdivisions of the main range into smaller geographical areas in this study was achieved by consideration of likely geographical or ecological barriers that would interfere with dispersal. Specimens from these semi-isolated areas were then combined into one sample. Four main barriers to dispersal pointed out by Pohle (1920), are arid areas, mountains, glaciated areas, and salt water straits*. On the other hand, drainage systems may be considered to be the primary avenues for dispersal, on the likely assumption

* Otters are littoral forms and apparently averse to crossing wide stretches of salt water. There is no evidence that they crossed Wallace's Line, for example, although they occur on many islands on the continental shelf, e.g., Newfoundland, Queen Charlotte Islands, Trinidad and others that they presumably reached over former land connections or at a time when the water gaps were narrow. 


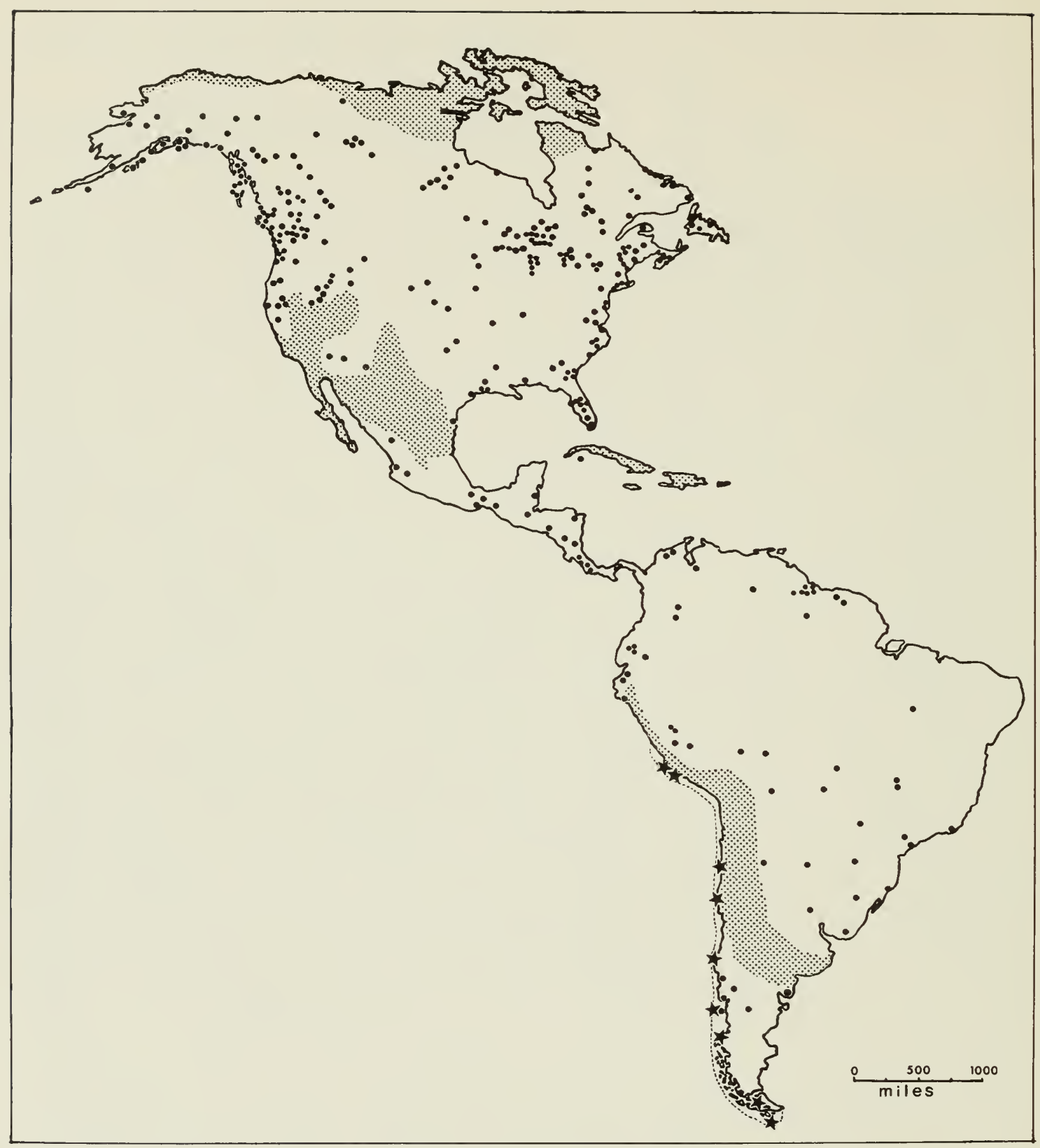

Fig. 1. The distribution of river otters in the Western Hemisphere. Localities from which specimens have been examined are shown by solid circles and by solid stars for localities of $L$. felina to distinguish them from those of $L$. provocax. Shaded parts represent areas where otters do not occur.

that otters tend to move along streams more often than not. The extent of overland exchange between two adjacent drainage systems will vary with the distance between them and the nature of the intervening country.

Despite these considerations, geographic ranges often had to be drawn arbitrarily. One such example was the delimitation of the range of $L$. c. interior, which shares the same river system with $L$. c. canadensis to the north and L. c. texensis to the south. Another is the border line between L. c. pacifica and L. c. nexa in the western United States.

Of the 34 described forms of Lutra occurring in the Americas, 32 were represented in this study; no specimens of $L$. mesopetes and $L$. enudris insularis could be obtained. In some taxa sample size was so small that they were compared separately and omitted from the overall analysis or combined with adjacent forms if geographic considerations, of the kind 
discussed above, and similarity of characters seemed to justify such an action. In $L$. canadensis, the forms extera (one specimen) and sonora (three specimens) were excluded from the general analysis. Data from the South American subspecies of $L$. annectens, L. a. colombiana, L. a. emerita, and $L$. a. parilina, were pooled as were those of $L$. enudris, L. e. incarum and L. e. mitis because of small sample size. L. c. canadensis, on the other hand, was subdivided into five geographic groups, those from the Canadian Shield and Hudson Bay area of Ontario and southern Quebec, those from northern New York State, those from Michigan, those from the Maritimes and New England States and a sample from the northern Mississippi drainage system. The total number of groups for analysis was thus 30 for the American forms of Lutra. In addition, eight species representing all but one of the Recent genera of the subfamily were included for comparison. The genus Paraonyx was not included because only one skull was examined. The large sample of L. lutra was subdivided into three geographic groups representing Europe, eastern Asia, and Japan, bringing the total number of groups to 40 .

\section{Methods of Analysis}

To achieve the aims set forth in the introduction, the general approach was to obtain estimates of morphological differences in the various taxa from a large number of cranial characters and, with other evidence, use these estimates to infer the systematic relationships of populations of river otters. To establish an estimate of the degree of variation within a species, populations of $L$. canadensis were investigated at the infra-specific level. Geographic variation within the South American species was not analyzed to the same degree as in L. canadensis because of smaller samples and a more uneven geographic representation; emphasis was on comparisons between the currently recognized species and on an evaluation of their specific status. Finally, the position of the group of American Lutra within the subfamily was re-evaluated, using the same skull characters and including additional morphological characters.

\section{UNIVARIATE ANALYSIS}

A univariate analysis was used to investigate geographic variation in size. The means, 95\% confidence intervals for the mean, the standard deviation and the observed range for the basal length of the skull of the different samples were computed and plotted in the form of a Dice-Leraas diagram. The basal length of the skull was used as an indicator of overall size, in the absence of a sufficient number of body measurements. This procedure has the limitation that skull length cannot serve as a precise and direct indicator of body-length, as the skull itself tends to grow with negative allometry (i.e., slope $<1$ ) in relation to the rest of the body in most mammals (Bährens, 1960). Males and females were plotted separately (Fig. 2) and combined, including unsexed specimens (Fig. 3), since in many cases unisexual samples were small. Only fully adult specimens, with completely fused cranial sutures were used in the comparison. Differences 
in the means of adjacent populations were tested using Student's $t$ test, if the Dice-Leraas diagram did not show conclusive evidence one way or the other. Only male samples were tested unless stated otherwise. Sexual dimorphism in the size of the skull was investigated using the expression $\frac{\bar{Y}{ }^{*}-\vec{Y} q}{\overline{Y^{*}}} \times 100$, where $\bar{Y}{ }^{*}$ represents the mean basal length in the males and $\bar{Y} q$ that of the females.

\section{BIVARIATE ALLOMETRIC ANALYSIS}

All skull and tooth measurements of the platensis group were subjected to a bivariate allometric analysis. The method has been used in a number of papers dealing with mammalian systematics (e.g., Bohlken, 1961, 1964; Kurtén and Rausch, 1959; Bährens, 1960). Gould (1966) reviewed the subject in a general context and gave an extensive bibliography. Bivariate allometric analysis was chosen as it reveals the effects of size on characters and at the same time compares homologous characters in otters of different size by eliminating the factor of size. It also analyzes and compares variation in shape, by breaking down a relatively complex shape or structure into a number of component bivariate relations.

Statistical methods used here follow Simpson et al. (1960). Bartlett's "best fit" line was used to represent the allometric trend. The correlation coefficient $r$ was calculated to determine the degree of concomitant change in any two characters and to evaluate whether the calculated allometric trend represents a real trend. Two or more samples can be compared as to slope $(B)$, elevation and scatter around the trendline.

The scatter for the Neotropical forms is represented by the logarithm of the individual observations. The distribution of $L$. provocax is delimited by a hand drawn line surrounding the scatter of points to facilitate evaluaation of its position. L. canadensis is represented by a $95 \%$ equal frequency ellipse, derived from more than 200 paired observations for each bivariate relationship and representing nearly all subspecies. The ellipse encompasses $95 \%$ of the observations and allows for easy comparison of the bivariate distribution for the different forms. The means for the subspecies of $L$. canadensis are also plotted. The slope of the major axis of the frequency ellipse furnishes an estimate for the intraspecific coefficient of allometry of L. canadensis. All the above calculations were carried out by computer.

Discrimination of differences within $L$. canadensis was achieved by evaluating the deviation of the sample means of each subspecies from the general allometric trend for the species (Bährens, 1960; Gould, 1966). The subspecies arrange themselves closely along the intraspecific allometric trend line. Marked deviation from the general allometric trend indicates divergence from the species pattern implying the involvement of genetic factors other than those responsible for size. Divergence of the Neotropical forms was assessed by a visual comparison of their bivariate distributions with that of $L$. canadensis and by comparing their coefficients of allometry where possible. The degree of difference can be judged from the extent to which their bivariate distributions overlap, the difference in elevation rela- 
tive to the $Y$ co-ordinate and the similarity of the coefficient of allometry as estimated by $B$.

\section{ESTIMATION OF SIMILARITY BY TAXONOMIC DISTANCE}

To evaluate further the taxonomic position of the American river otters relative to other members of the genus Lutra, and to reassess the delimitation of the genus with respect to other genera in the subfamily, methods developed by numerical taxonomists (Sokal and Sneath, 1963) were employed. These methods make it possible to quantify degrees of similarity and thereby estimate the distance between different forms. They thus provide a useful and relatively objective yardstick in making taxonomic decisions and inferences about the relationships of the forms being compared.

A number of mathematical coefficients has been developed to express phenetic similarity (Sokal and Sneath, 1963) but taxonomic distance is used here. The 48 characters used (Appendix 2) were predominantly cranial and dental, but a number of other characters were also included. Only numerical characters were used, and no attempt was made to code numerically characters that were difficult to quantify. Cranial and dental characters were expressed as ratios $\frac{\Sigma X / N}{\Sigma Y / N}$, where $X$ and $Y$ are linear dimensions of one anatomical element and $\mathrm{N}$ the number of measurements in a sample. Simpson et al. (1960) pointed out the drawbacks in the use of ratios. An important one of these is that ratios of two dimensions that grow allometrically change constantly. When the divisor is a function of size, ratios are however independent of size, a factor which would be weighted if original measurements were used.

Calculation of the coefficients was carried out by computer. The program produced print-outs of the original data matrix with means and standard deviations and a half-matrix of the distance coefficients, not reproduced here because of space limitations but available elsewhere (van Zyll de Jong, 1968). The clustering operations of the weighted pair-group method (Sokal and Sneath, 1963) were also performed by computer.

Delimitation of the taxonomic groups on the phenogram was achieved by considering criteria that differ for the species and higher categories. The subspecies presents a special case, as it is commonly based on characters that vary continuously rather than on those that vary discontinuously. In a phenogram, subspecies would occur in a cluster separated by low distance coefficients. Only relatively isolated and well differentiated subspecies could be expected to show gaps separating them clearly from the others. The problem of delimiting subspecies is further discussed under results and discussion.

As the currently recognized species of American Lutra comprise a series of at least three allopatric populations and only L. provocax and L. felina are sympatric, the criterion of interbreeding is irrelevant in determining their specific status. Ranges of the three Neotropical taxa, L. annectens, L. enudris and L. platensis, are in contact and evidence of interbreeding, or the lack of it, could be obtained from the areas of contact, but is largely unavailable at the present time. In delimiting the species, criteria suggested 
by Mayr et al. (1953) were used. The degree of difference between sympatric species and between intergrading subspecies within widespread species were used as a yardstick to determine the status of the isolated populations.

Mayr et al. (1953) defined higher categories by the two criteria of monophyly and taxonomic, usually morphologic, gaps (see also Simpson, 1961). A higher taxon, whether genus, family or any category above it, includes one or more of the taxa directly below it, which are inferred to be monophyletic, and is separated from equivalent groups by a decided gap. These gaps were estimated by the distance coefficient in this study, as were the gaps between the species, and are graphically depicted by the levels at which the different clusters join. The levels at which the cut-offs for the higher categories are drawn are somewhat more arbitrary than in the case of the species.

The genus, as Mayr (1942) pointed out, lacks the objective reality of the species, and where the borders of the genus are drawn is left to the subjective judgment of the taxonomist. The same also applies to other categories above the species. Use of a numerical technique does not eliminate arbitrary judgment in delimiting higher categories; it does however reduce bias by considering simultaneously and weighing equally a large number of characters from several groups. Resulting categories therefore reflect the degrees of difference between forms more faithfully and produce a more balanced classification. The level at which genera are delineated is determined from recognizable clusters in the phenogram and by a consideration of the adaptive facies of the clusters.

COLORIMETRIC ANALYSIS

Sixty-nine skins representing 11 subspecies of $L$. canadensis and seven Neotropical taxa were analyzed to compare coloration. Reflectance values for 10 different wavelengths between $415 \mathrm{~nm}-685 \mathrm{~nm}$ were obtained with a Bausch \& Lomb Spectronic 20 colorimeter, with a colour analyzer reflectance attachment for ventral and dorsal areas. Readings obtained were expressed as the percentage of light reflected at each wave length, using magnesium carbonate as a standard (100\% reflectance). These readings were then plotted to form a reflectance curve and used to calculate the tristimulus values $\mathrm{X}, \mathrm{Y}$ and $\mathrm{Z}$ from which the trichromatic coefficients $\mathrm{x}$ and $\mathrm{y}$ can be derived using Bausch \& Lomb's trichromatic coefficient computing forms. The trichromatic coefficients were transformed to dominant wavelength $(\mathrm{nm})$, purity $(\%)$ and brightness $(\%)$ describing the colour, using the charts in Hardy (1936) designed for this purpose. Individual readings were used to calculate a mean reflectance curve for each sample from which dominant wave length, purity and brightness were calculated.

\section{System of Mensuration}

With a few exceptions cranial and dental measurements taken were those of Pohle (1920). This choice of measurements made it possible to include here a large amount of data contained in Pohle's tables. A smaller number of measurements of L. lutra were also taken from Ognev (1962).

A total of 31 measurements, defined below, were taken on each skull and combined into 40 variate pairs for analysis. 


\section{LIST OF MEASUREMENTS}

1. Basal length. From basion to gnathion.

2. Interorbital width. Narrowest part between the orbits.

3. Width between postorbital processes.

4. Orbito-nasal length. From tip of a postorbital process to anterior end of median suture of nasals.

5. Width of postorbital constriction measured at posterior and usually narrowest part (except in Pteronura, Fig. 28) of the postorbital constriction.

6. Rostral width at canines.

7. Basal skull width. Smallest distance across skull, between zygomaticsquamosal process and mastoid process.

8. Width of braincase. Greatest width of braincase.

9. Mastoid width. Greatest width between mastoid processes.

10. Depth of braincase. Measured from parietal dorso-ventrally to anterior end of basioccipital excluding median ridge.

11. Depth of bullae. Subtract depth of braincase (10) from depth of braincase including bullae.

12. Zygomatic width. Greatest width between the distal surfaces of the zygomatic arches.

13. Occipital height. Distance from dorsal rim of foramen magnum to occiput.

14. Palatal length. Medial distance from gnathion to posterior edge of palatines.

15. Length of bullae. From anterior carotid foramen to stylo-hyoid pit.

16. Length of mandible. Distance from most anterior part of symphysis to external end of condyle.

17. Depth of mandible. Height of ramus directly anterior to $\mathbf{M}_{1}$.

18. Length of upper premolar-molar series.

19. Mesiodistal length of $\mathrm{P}^{3}$.

20. Bucco-lingual width of $\mathrm{P}^{3}$.

21. Talon length of $\mathrm{P}^{4}$, measured from anterior part (parastyle) to posterior margin of talon.

22. Buccal length of $\mathrm{P}^{4}$. From parastyle to end of metacone.

23. Greatest width of $\mathrm{P}^{4}$. Greatest distance perpendicular to paraconemetacone axis of tooth.

24. Lingual length of $\mathrm{M}^{1}$. Length of talon.

25. Buccal length of $\mathbf{M}^{1}$. Distance along paracone-metacone axis.

26. Greatest diameter of $\mathbf{M}^{1}$. Distance from parastyle to hypocone.

27. Length of mandibular premolar-molar series.

28. Mesiodistal length of $M_{1}$.

29. Bucco-lingual width of $M_{1}$ at talonid.

30. Mesiodistal length of $\mathbf{M}_{2}$.

31. Bucco-lingual width of $\mathrm{M}_{2}$. 


\section{Results and Discussion}

\section{Geographic Variation in Size}

The samples are arranged when possible in sequences of geographically adjacent groups (Fig. 2 and 3 ). In interpreting the results of the analysis it should be remembered that the size differences of the skull probably indicate larger differences in body length.

Another factor in the analysis is that the degree of resolution obtained in a graphic analysis of this type depends not only on the number of specimens in each sample, but also on the number of geographically sequential samples into which the total sample can be divided. A restricted area in which a steep cline occurs within a major cline, for example, cannot be detected if it is not represented in the sample.

The largest river otter in North America, Lutra mira, occurs on Prince of Wales and adjacent islands in southeastern Alaska. Neighbouring populations from the Queen Charlotte Islands (L.c. periclyzomae), the coastal areas of British Columbia and the Alaskan panhandle (L. c. pacifica) and Vancouver Island (L. c. vancouverensis) are all significantly smaller ( $\mathrm{P}<.01 ; \mathrm{P}<.01$ and $\mathrm{P}<.02$ respectively). These three groups do not differ significantly from one another (pacifica from British Columbia and periclyzomae $.6<\mathrm{P}<.7$; pacifica from British Columbia and vancouverensis . $2<\mathrm{P}<.3$ ).

The Dice-Leraas diagram suggests a diminution in size toward the south into Washington (L. c. pacifica) as well as toward the east into the interior of British Columbia (L.c. evexa), Idaho and Nevada (L. c. nexa). Of the adjacent taxa mentioned, only evexa and pacifica from the coast of British Columbia differ significantly $(.02<\mathrm{P}<.05)$. British Columbia pacifica and pacifica from Washington and Oregon do not differ significantly $(\mathrm{P}=.7)$. Coastal pacifica (Washington and Oregon) do not differ from nexa in the interior $(.7<\mathrm{P}<.8)$. The smallest western river otters (L. c. brevipilosus) are found in California. The difference of brevipilosus from pacifica from Oregon and Washington to the north is probably not significant $(\mathrm{P}=.05)$, but the difference from pacifica from British Columbia is significant $(.02<\mathrm{P}<.05)$.

L. c. sonora, the only other subspecies west of the Rocky Mountains, is unfortunately represented by only three specimens, one of which, a male, represents the longest skull of the entire sample $(120.2 \mathrm{~mm})$. This subspecies is usually regarded as one of the largest, but this contention may be based solely on this skull, which may represent an infrequent size in the population. Basal lengths of the other specimens, a younger male (102.3 $\mathrm{mm})$ and a female $(103 \mathrm{~mm})$ are within the range of $L$. c. nexa, the subspecies to the north. The difference between the nexa and sonora samples was not significant $(.3<\mathrm{P}<.4)$. Whether the population inhabiting the Colorado River system actually constitutes a larger form can only be ascertained from a larger sample.

Northwest of the Alaskan panhandle, from Yakutat Bay to the Kenai Peninsula, a significantly smaller race (L. c. optiva) is found. The insular 


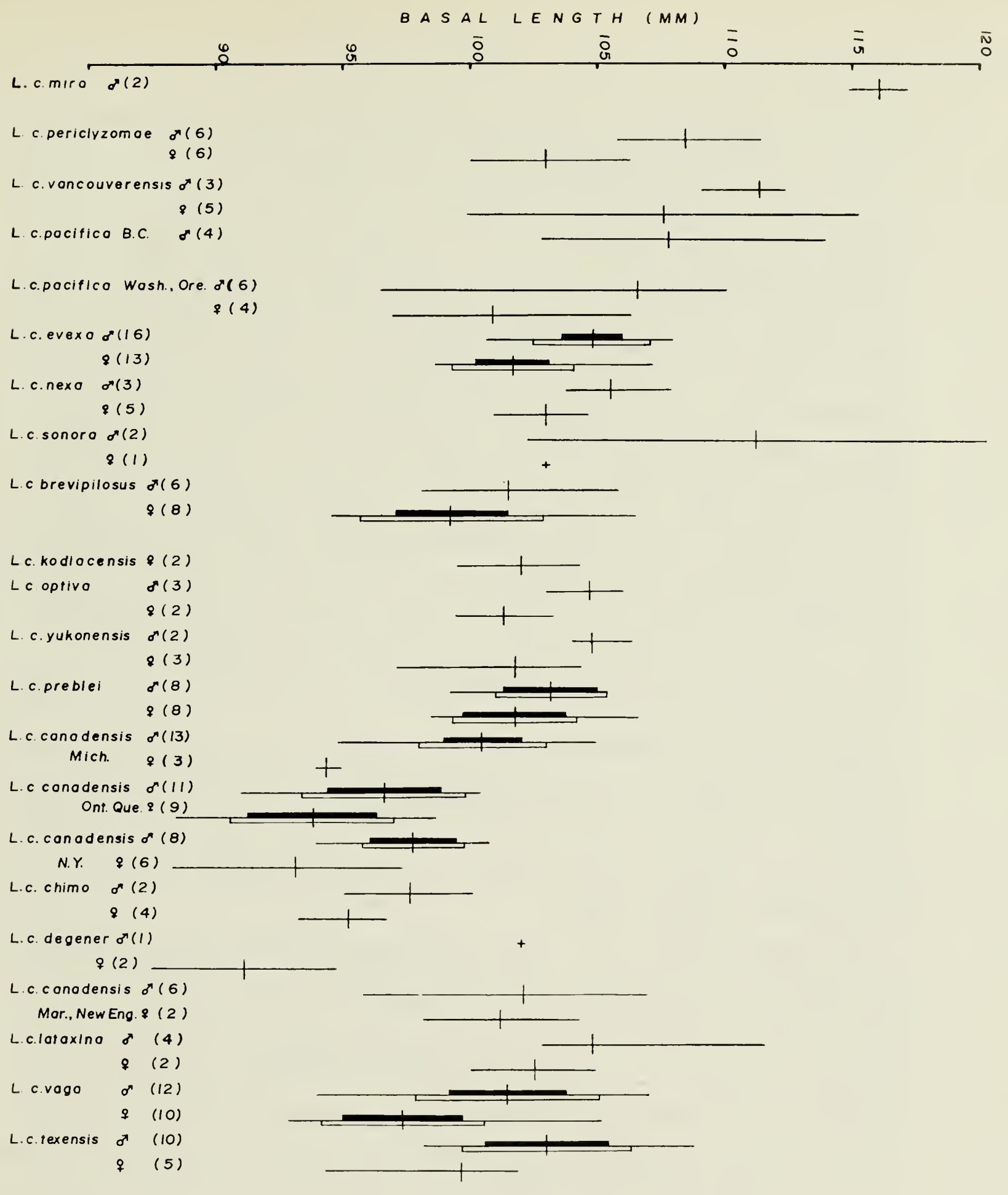

L.o. onnectens o (5)

\& (1)

L. o. lotidens of (3)

\& (3)

Lo repando or (3)

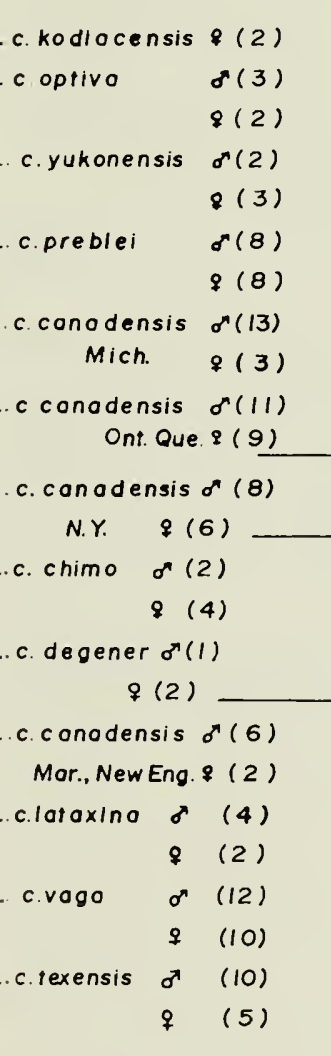

\& (2)

L.o. subspp. of (4)

S. Am. $q$ (4)

L. enudris of (9)

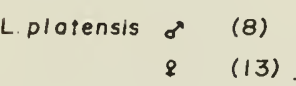

L. provocax of (3)

8 (1)

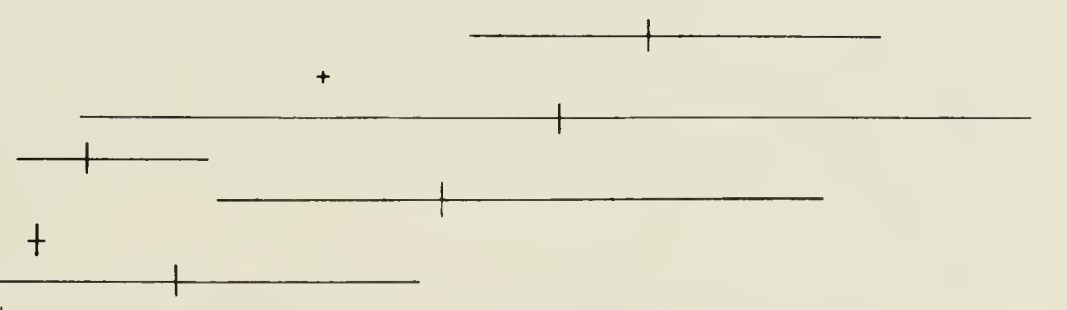

Fig. 2. Dice-Leraas diagram showing geographic variation of the basal length in samples of adult male and female American river otters. The mean, $95 \mathrm{c}^{\mathrm{c}}$ confidence limits for the means (black rectangle). standard deviation (clear rectangle) and observed range are shown. 
form, L. c. kodiacensis, is similar in size. In the interior of Alaska in the Yukon Territory and on the Alaska Peninsula, yukonensis is a slightly smaller form than the coastal optiva, but the difference may not be significant $(.4<\mathrm{P}<.5$ for the male samples, but $.02<\mathrm{P}<.05$ for the mixed sample). The sole specimen of $L$. c. extera, from Nagai Island off the southern tip of the Alaska Peninsula, falls within the range (basal length $102.8 \mathrm{~mm}$ ) of adjacent populations and does not differ significantly from the mainland yukonensis across the strait $(.3<\mathrm{P}<.4)$. To the east males of L. c. preblei are somewhat smaller but do not differ significantly from yukonensis $(.3<\mathrm{P}<.4)$. The mixed sample of preblei however has a larger mean, and the difference is significant $(P=.02)$. The canadensis from Ontario and southern Quebec are considerably smaller than preblei $(\mathrm{P}<.001)$. Other otters described from eastern Canada, L. c. chimo of northern Quebec and Labrador and $L$. c. degener from Newfoundland, as well as specimens from northern New York State, are similar in size to populations in Ontario and southern Quebec and do not differ significantly $(\mathrm{P}<.7$ for chimo and canadensis from Ontario and Quebec and $\mathrm{P}<.4$ for chimo and degener). The smallest North American river otters appear to occur in Newfoundland.

Otters from the Maritimes and New England (L. C. canadensis) are significantly larger than canadensis from Ontario and Quebec $(.001<\mathrm{P}$ $<.01)$. Individuals of similar size occur throughout the Atlantic coastal plain (L. c. lataxina) south to Florida (L. c. vaga). This finding is contrary to the opinion that lataxina is one of the smallest subspecies of L. canadensis (Rhoads, 1898).

The central plains of the North American continent, encompassing the Mississippi drainage system and smaller adjacent river systems, are inhabited by otters similar in size to lataxina and vaga and include texensis, interior and canadensis from the northern and eastern parts of the Mississippi basin. Along the Gulf coast of Louisiana and Texas texensis is somewhat larger than vaga, but the difference is not significant $(\mathrm{P}<.3)$. To the north interior does not differ significantly from canadensis from Michigan and the northern Mississippi basin; these populations of canadensis in turn are not much smaller than preblei which occupies the extensive river and lake systems in Canada to the north. The neighbouring races west of the Rocky Mountains (evexa, nexa and sonora) already compared have slightly greater mean basal lengths. Observed differences are however not statistically significant (evexa and preblei $.1<\mathrm{P}<.2$; interior and nexa, mixed samples, .05 $<\mathrm{P}<.10$ ).

An analysis of geographic variation similar to that for L. canadensis could not be carried out for the Neotropical otters, as sample sizes were not large enough. Limited information was obtained however. In $L$. annectens, a north-south cline of decreasing size is evident. The smallest animals occur in Colombia and Ecuador. None of the adjacent forms in the north-south sequence differ significantly, but the two most widely separated samples do differ (L. $a$. annectens and the combined South American subspecies colombiana, emerita and parilina; $\mathrm{P}<.001)$. The combined sample of $L$. enudris has a similar range of variation in size as that of $L$. annectens. 

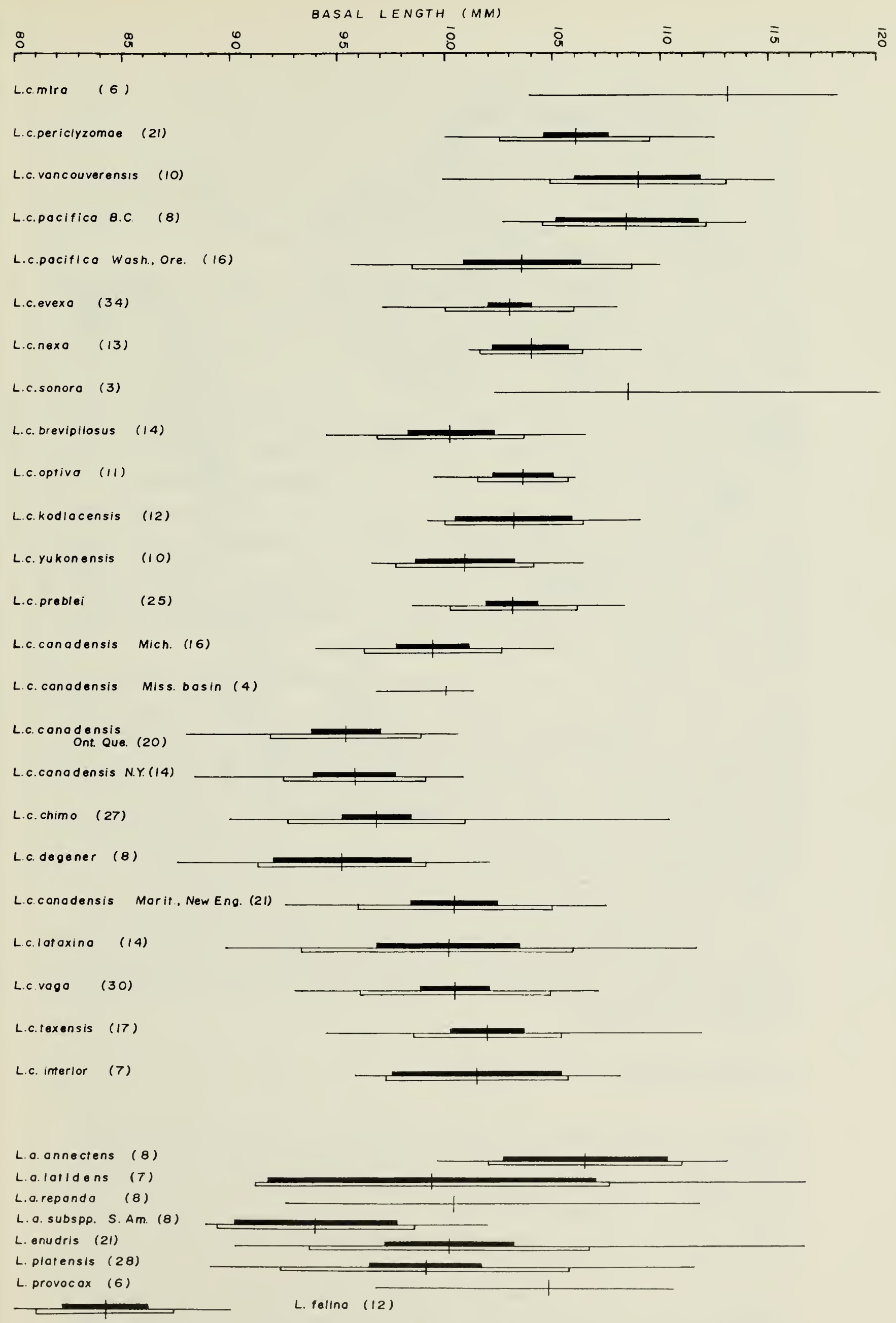

Fig. 3. Dice-Leralas diagram showing geographic variation of the basal length in mixed samples of adult specimens, including those of unknown sex. Details as in Fig. 2. 
Geographic variation in size within the large area of its distribution could not be analyzed statistically because of inadequate samples. L. platensis does not differ significantly from L. enudris $(.4<\mathrm{P}<.5)$ or from $L$. provocax $(.8<\mathrm{P}<.9)$. The smallest otter of the group is L. felina, the largest specimens reaching the size of the smallest representatives of the other forms. Again the pattern of geographic variation could not be determined because of inadequate samples.

The above findings may be briefly summarized as follows. Populations of large otters occur along the Pacific coast and offshore islands of southeastern Alaska and British Columbia, the largest on Prince of Wales and adjacent islands. There is a possible clinal decrease in size towards the south, the smallest occurring in California. In other populations west of the Rocky Mountains but farther inland, clinal change is not evident. In the north evexa is similar to preblei in size; the more southern subspecies nexa and sonora are more similar to pacifica from Washington and Oregon.

Of the populations occurring in the northern half of the continent, those in the Yukon River system (yukonensis) may be somewhat smaller than populations in northern and central Canada (preblei). The smallest otters are found in Ontario, Quebec, Labrador and Newfoundland. The decrease in size from Alaska to Manitoba is slight, if any, but the decrease from Manitoba to Ontario appears to be relatively abrupt.

Little change in size occurs in populations inhabiting the remaining areas of the United States and the Maritime Provinces of Canada. Mean basal length is more than $100 \mathrm{~mm}$ for samples of males and females combined throughout this area, and only in areas bordering the geographic range of the small northeastern otters mentioned above are smaller values obtained (Michigan $99.4 \mathrm{~mm}$, northern New York $95.8 \mathrm{~mm}$ ). An approximation of the distribution of relative size of $L$. canadensis, as indicated by the basal length of the skull, is given in Fig. 4.

For the Neotropical forms a clinal change in size could only be shown for $L$. annectens; geographic variation of size in other Neotropical otters could not be studied because of small samples. Comparison of Nearctic and Neotropical forms, not including L. felina, reveals overall range of variation in size to be similar.

\section{Sexual Dimorphism}

Females are smaller than males (Fig. 2). In L. canadensis the index of sexual dimorphism ranges from 1 to 10 for the different population samples and averages 4 for the species (all values to the nearest 1\%). In Neotropical forms the index ranges from 4 to 12 . Indices for samples representing the subspecies of $L$. annectens range from 11 in $L$. a. latidens to 4 in the South American subspecies. L. enudris has an index value of 8 , L. platensis 12 and L. provocax 10 . The mean value for all large Neotropical forms is 9 , indicating a more pronounced sexual dimorphism in the Neotropical forms. The more pronounced sexual dimorphism is also evident from the larger standard deviations in Figure 3. Adequate material was 


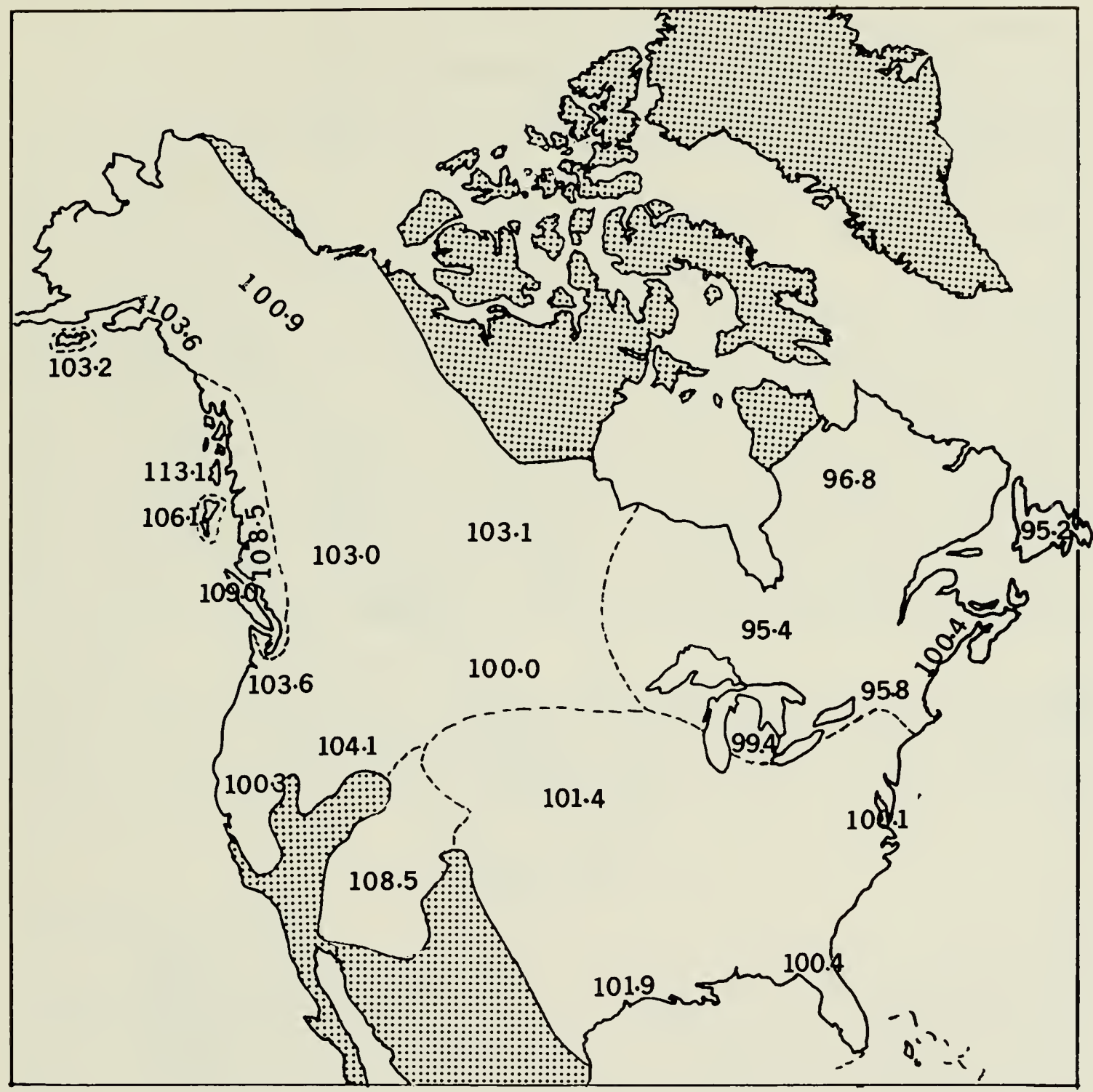

Fig. 4. Geographic variation of the basal length $(\mathrm{mm})$ in L. canadensis. Each number represents the mean for the adults of samples mentioned in the text. Means are located approximately in the centre of the area represented by the sample. Broken lines represent the geographic subdivisions of the species range as suggested by evidence of overall similarity.

not available for L. felina, although the sexes seem to be similar in size. Pohle (1920) stated that the platensis group is characterized by a greater degree of sexual dimorphism than other species in the genus, including L. lutra. Data pertaining to adult L. lutra taken from his tables contradict his statement. The index obtained from his data is 10 , a value similar to that of many Neotropical and some Nearctic forms.

Sexual dimorphism in other skull characters was not analyzed in detail, but a cursory examination revealed no obvious differences between sexes (see Hooper and Ostenson, 1949). Hysing-Dahl (1959) investigated sexual dimorphism in the skull of L. lutra and found that females, apart from being generally smaller, had a greater mean value for the width of the postorbital constriction. He was unable to find any characters by which the sex of individual skulls could be determined, however.

Hoerschelmann (1966) pointed out the effects of sexual dimorphism on intraspecific allometry. If the means of bivariate distributions of males and females lie on the intraspecific axis, the difference of proportion is only 


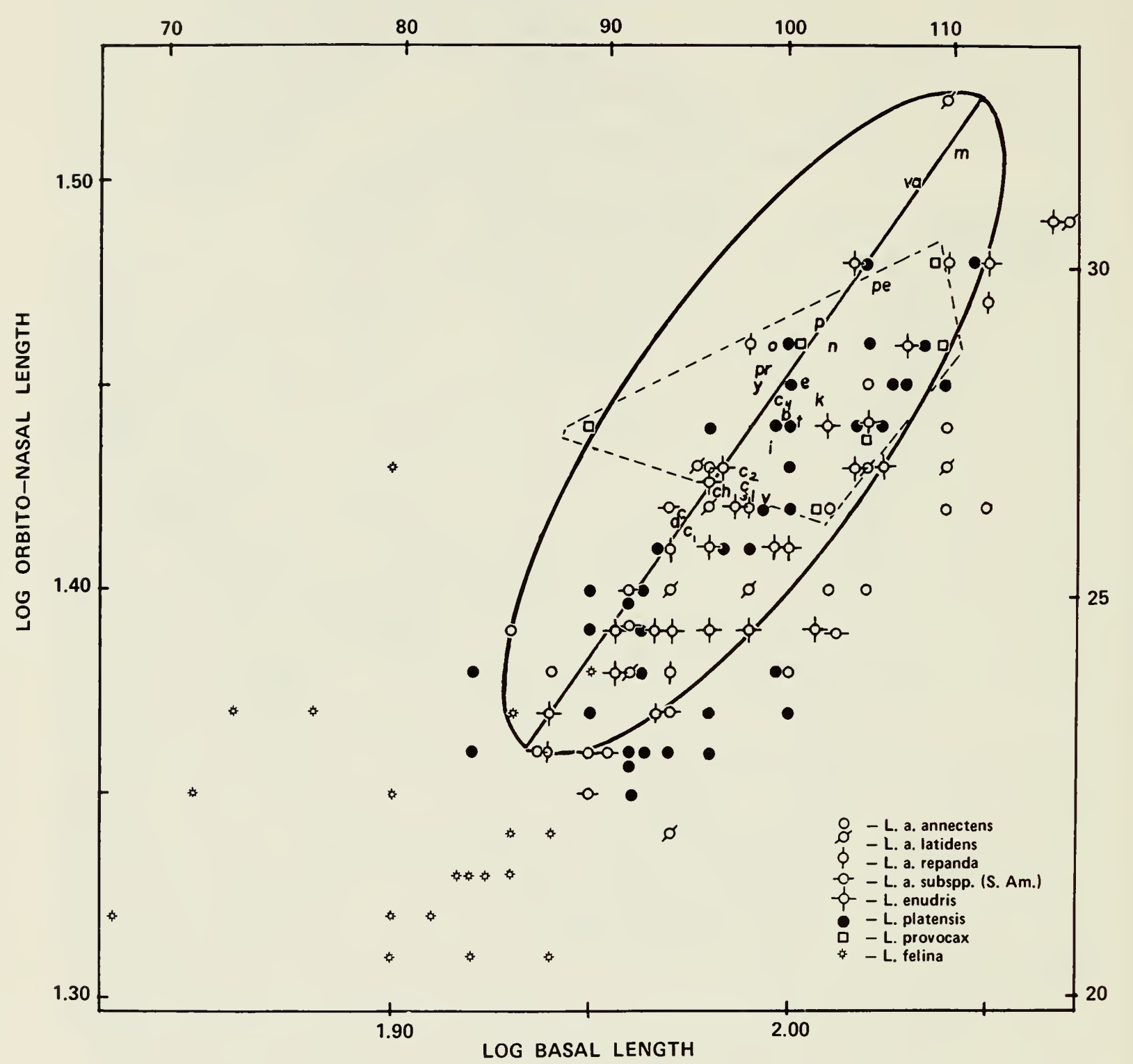

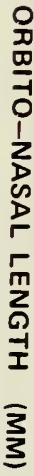

Fig. 5. Covariation between the orbito-nasal and basal lengths. The scatter diagram is logarithmic, showing logarithmic values along the left and lower axis and absolute values $(\mathrm{mm})$ along the right and upper axis. The bivariate distribution of $L$. canadensis is represented by a $95 \%$ equal frequency ellipse. The means for the subspecific samples of L. canadensis are indicated by lower case letters $(\mathrm{b}=$ brevipilosus; $\mathrm{c}=$ canadensis Ont.-Que. samples; $c_{1}=$ canadensis Mich.; $c_{2}=$ canadensis N.Y. State; $\mathrm{c}_{3}=$ canadensis Maritimes-N. Eng.; $\mathrm{c}_{4}=$ canadensis northern Miss. Basin; $\mathrm{d}=$ degener $; \mathrm{ch}=$ chimo; $\mathrm{e}=$ evexa $; \mathrm{i}=$ interior $; \mathrm{k}=$ kodiacensis; $\mathrm{l}=$ lataxina; $\mathrm{m}=$ mira $; \mathrm{n}=$ nexa $\mathrm{o}=$ optiva $\mathrm{p}=$ pacifica; $\mathrm{pe}=$ periclyzomae; $\mathrm{pr}=$ preble $; \mathrm{t}=$ texensis; $\mathrm{v}=$ vaga; va $=$ vancouverensis; $y=y$ ukonensis). The distribution of other forms is represented by their original scatter of points. The bivariate distribution of $L$. provocax is outlined by a stipple line to facilitate evaluation of its position. The slope for L. canadensis is 1.38 (95\% conf. limits $1.25-1.53 ; \mathrm{r}=0.79)$. 
because of size. If the means do not lie on the intraspecific axis, however, males and females differ not only in size but also in proportions. The degree to which the intraspecific axis is influenced by sexual dimorphism in an analysis including both sexes varies with differences in size and proportion between the sexes. When differences in size and proportion are small, the intraspecific axis is only slightly influenced, and the three means (for males, females and combined sample) lie close together.

A consideration of the influence of sexual dimorphism on the intraspecific allometry is important in view of the bivariate analysis that follows. Ideally, the comparison should be between samples of specimens of the same sex, but in practice this was not possible because of small sample sizes and the large number of specimens of undetermined sex. Nonetheless, examination of scatter diagrams, in which the sexes were plotted separately for some samples, gave no indication that possible sexual dimorphism in the bivariate relationships would result in drastically different allometric trends for the sexes. Therefore different geographic samples were treated as units.

Bährens (1960), who investigated sexual dimorphism in the skull of the mink, found that differences in the shape of the skull in the sexes could be largely explained by size differences although a number of differences were independent of size.

\section{Allometric Analysis}

Only 10 of the more divergent patterns of the bivariate relationships of the skull and dentition investigated by me (van Zyll de Jong, 1968) are considered here in some detail although other differences observed in the different otters are summarized. Selected measurements for the samples are given in Appendix 3.

\section{Orbito-nasal length and basal length (Fig. 5)}

The large Neotropical otters have a shorter orbito-nasal length than has L. canadensis. Overlap of the bivariate distributions of the two groups is nonetheless considerable. The scatter of $L$. provocax points coincides entirely with the location of $L$. canadensis. Other Neotropical otters do not differ appreciably among themselves. L. felina is distributed on either side of the L. canadensis axis.

Slopes for all samples are similar, and the allometric coefficients of the samples did not differ significantly. L. felina and L. provocax, however, have low correlations ( $r=.21$ and .27 , respectively) and do not display significant trends. The means for the subspecies of $L$. canadensis are located relatively evenly along the intraspecific trend.

\section{Postorbital constriction and basal length (Fig. 6)}

These parameters did not show any significant trend, the characters varying independently of one another in the majority of forms. A similar situation exists in mink (Bährens, 1960). Significant trends were seen in only 


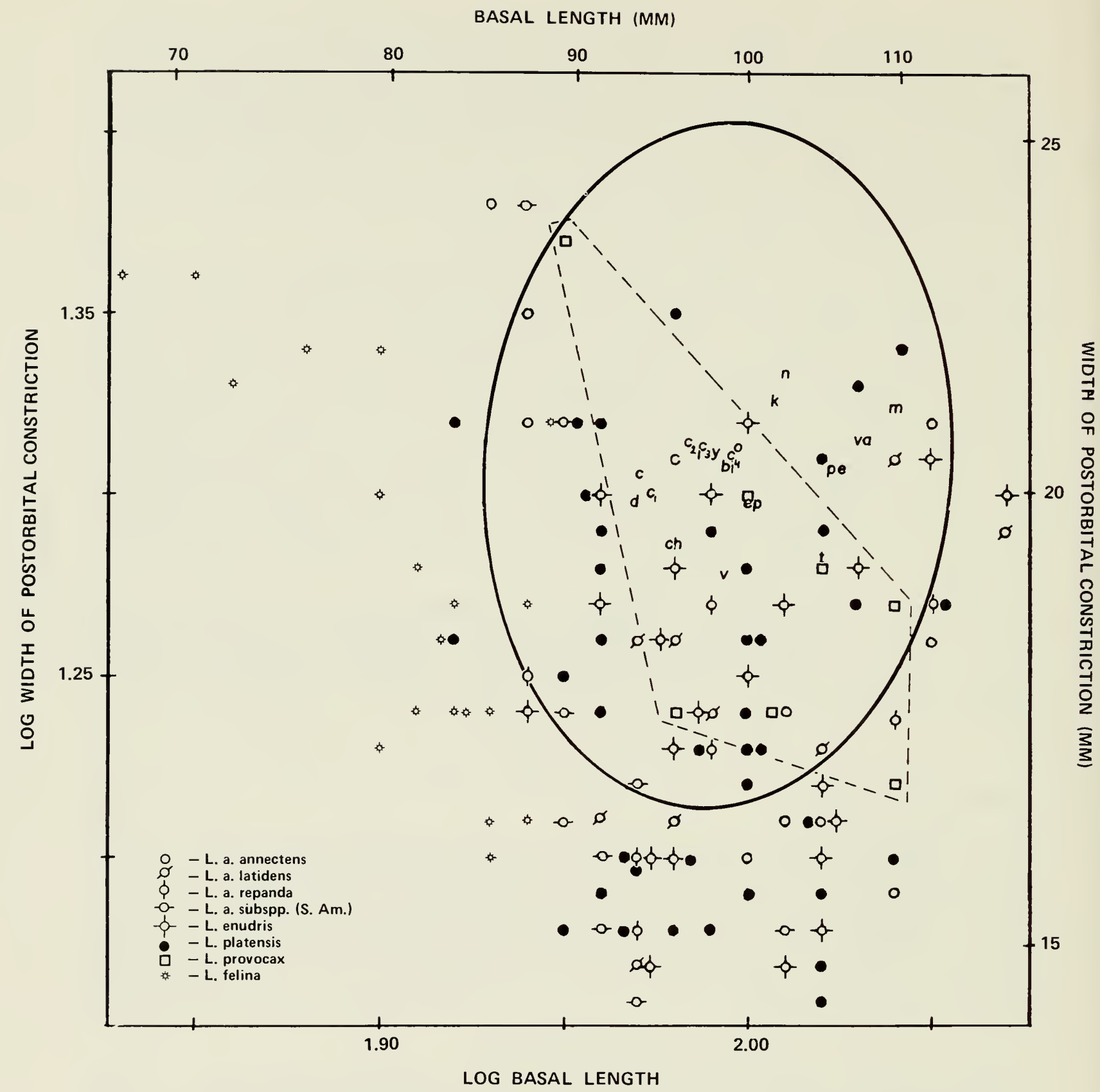

Fig. 6. Covariation between the width of the postorbital constriction and basal length. Probably the only significant trend occurs in L. felina (slope - 1.35; $r=0.68)$. See caption of Fig. 5 for abbreviations.

L. felina, L. a. annectens and L. a. latidens. Allometry was negative in $L$. felina and $L$. annectens, the absolute dimension of the constriction decreased with increasing size. In L. a. annectens and L. a. latidens sample size was small and the trend may not have reflected the actual trend in the population. The postorbital constriction was broader in L. canadensis than in the Neotropical forms.

In $L$. canadensis the narrowest postorbital constriction was found in vaga (approximately $21 \%$ of basal length) and narrow postorbital constrictions ( $20 \%$ of basal length) were also found in vancouverensis, periclyzomae, pacifica, mira and evexa. The postorbital constriction was relatively broad in Ontario, Quebec, and samples of Maritimes-New England canadensis, degener, lataxina and nexa. 


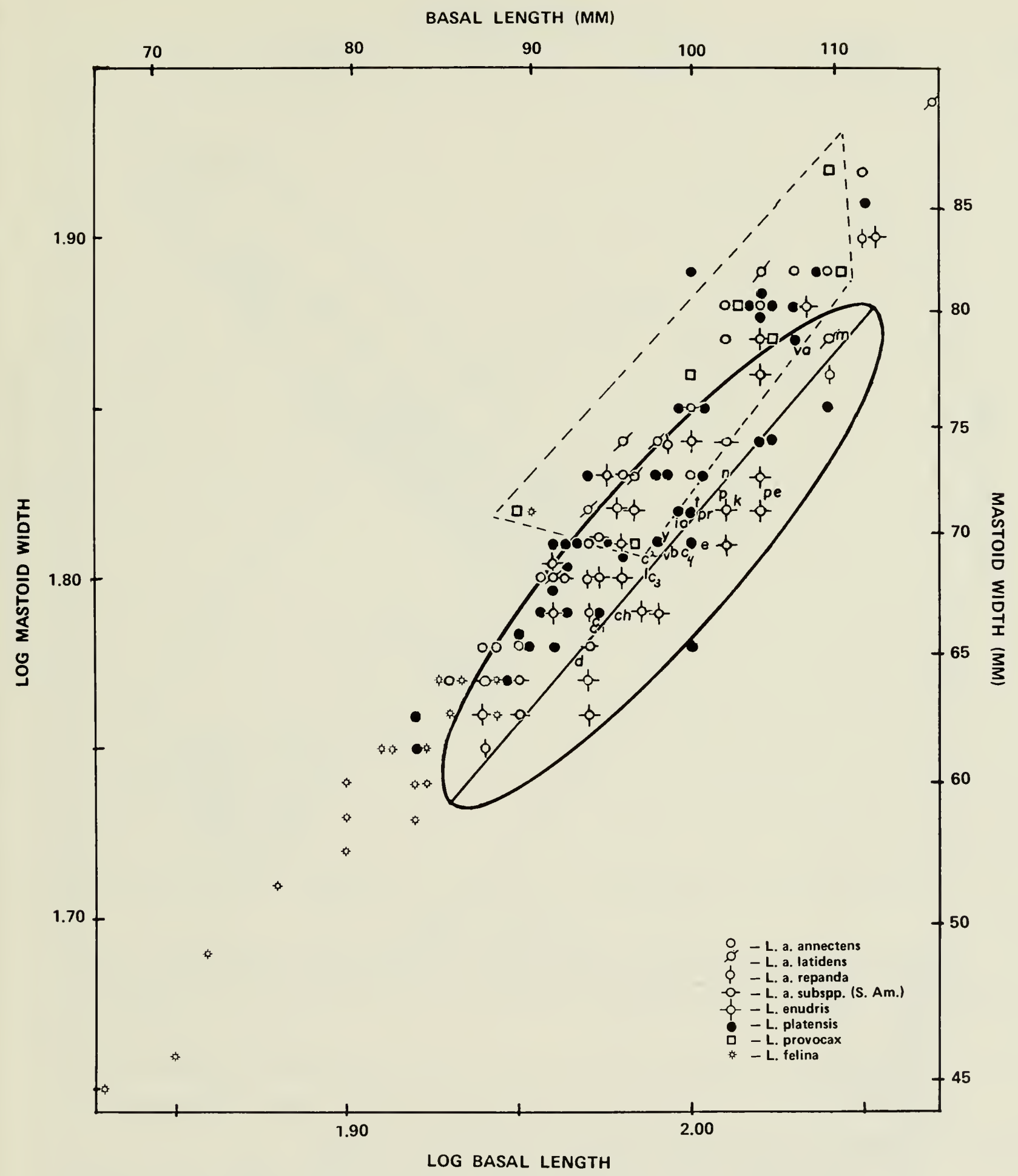

Fig. 7. Covariation between mastoid width and basal length. Slope for $L$. canadensis is 1.18 (95\% conf. limits, $1.11-1.27 ; \mathrm{r}=0.89)$. See caption of Fig. 5 for abbreviations.

Mastoid width and basal length (Fig. 7)

The distribution for this bivariate relationship in the Neotropical otters lies above that of $L$. canadensis, although the overlap is considerable. The difference is most pronounced in L. provocax, L. annectens and L. felina, less pronounced in L. enudris and L. platensis. In larger and older skulls of the Neotropical otters, particularly L. annectens and L. provocax, the mastoid processes tend to expand laterally (see Fig. 24 C, D and 26 A), whereas in $L$. canadensis they are smaller and often project ventrally (see Fig. 24 A, B). 


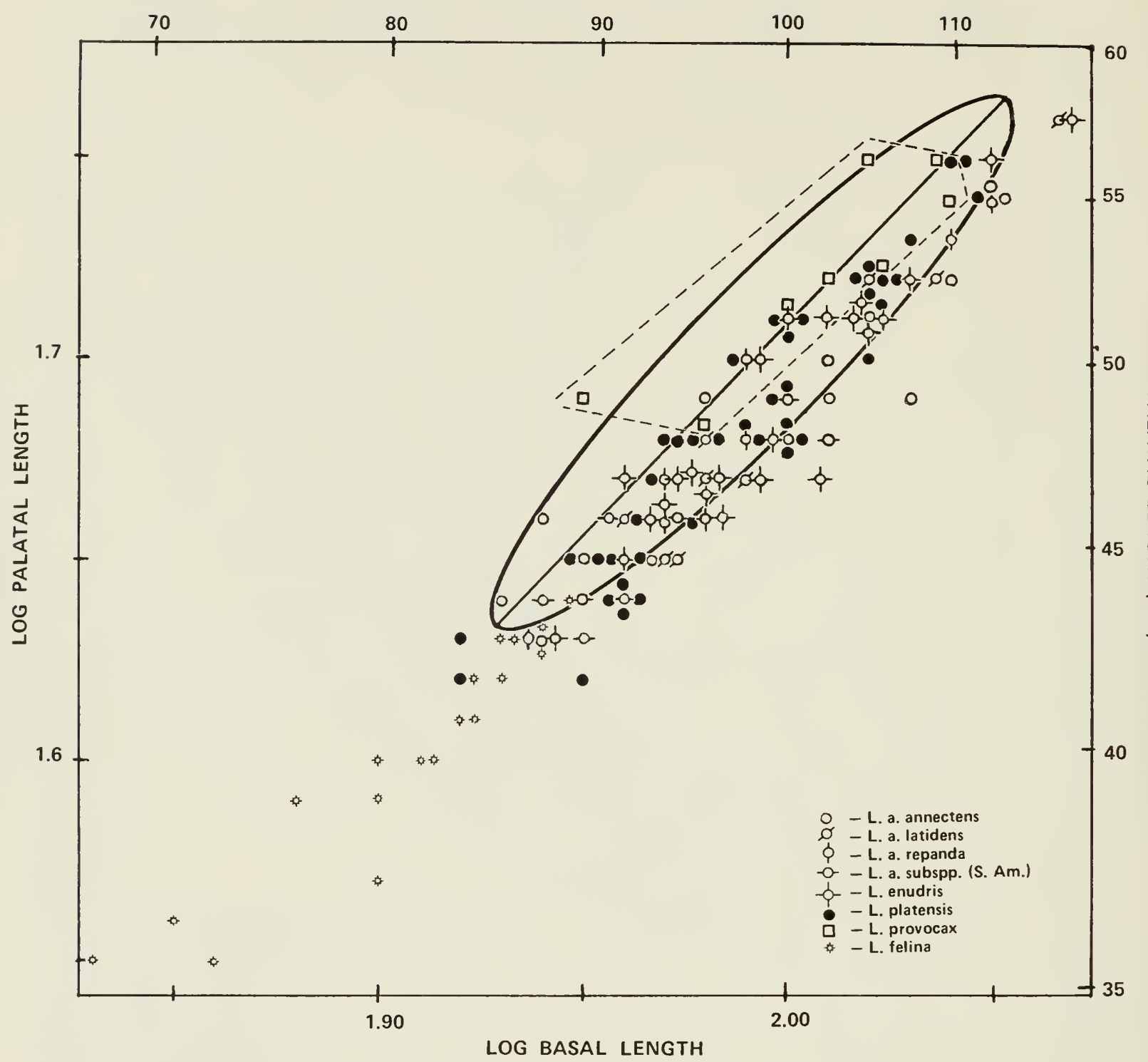

Fig. 8. Covariation between palatal length and basal length. Slope for $L$. cancdensis is 1.06 (95\% conf. limits, $1.01-1.12 ; r=0.93)$. See caption of Fig. 5 for abbreviations.

Coefficients of allometry tested did not differ significantly and the slopes for the trends of all forms are approximately the same. The allometric relationship of these parameters is only slightly positive.

The subspecies of $L$. canadensis lie, on the whole, rather near to the intraspecific trend, but periclyzomae has a noticeably smaller mastoid width and vancouverensis a much broader mastoid width than all other subspecies. Differences in evexa and kodiacensis, which also have a rather small mastoid width, are less pronounced.

Palatal length and basal length (Fig. 8)

The relative position of the bivariate distribution of $L$. canadensis is clearly above that of all Neotropical forms, with the exception of the bivariate distribution of $L$. provocax, which is much more similar to $L$. canadensis. Both taxa tend to have a relatively longer palate. The slopes of all samples tested do not differ significantly. The scatter diagram supports the view that all forms have approximately the same slope. An obvious divergence from 


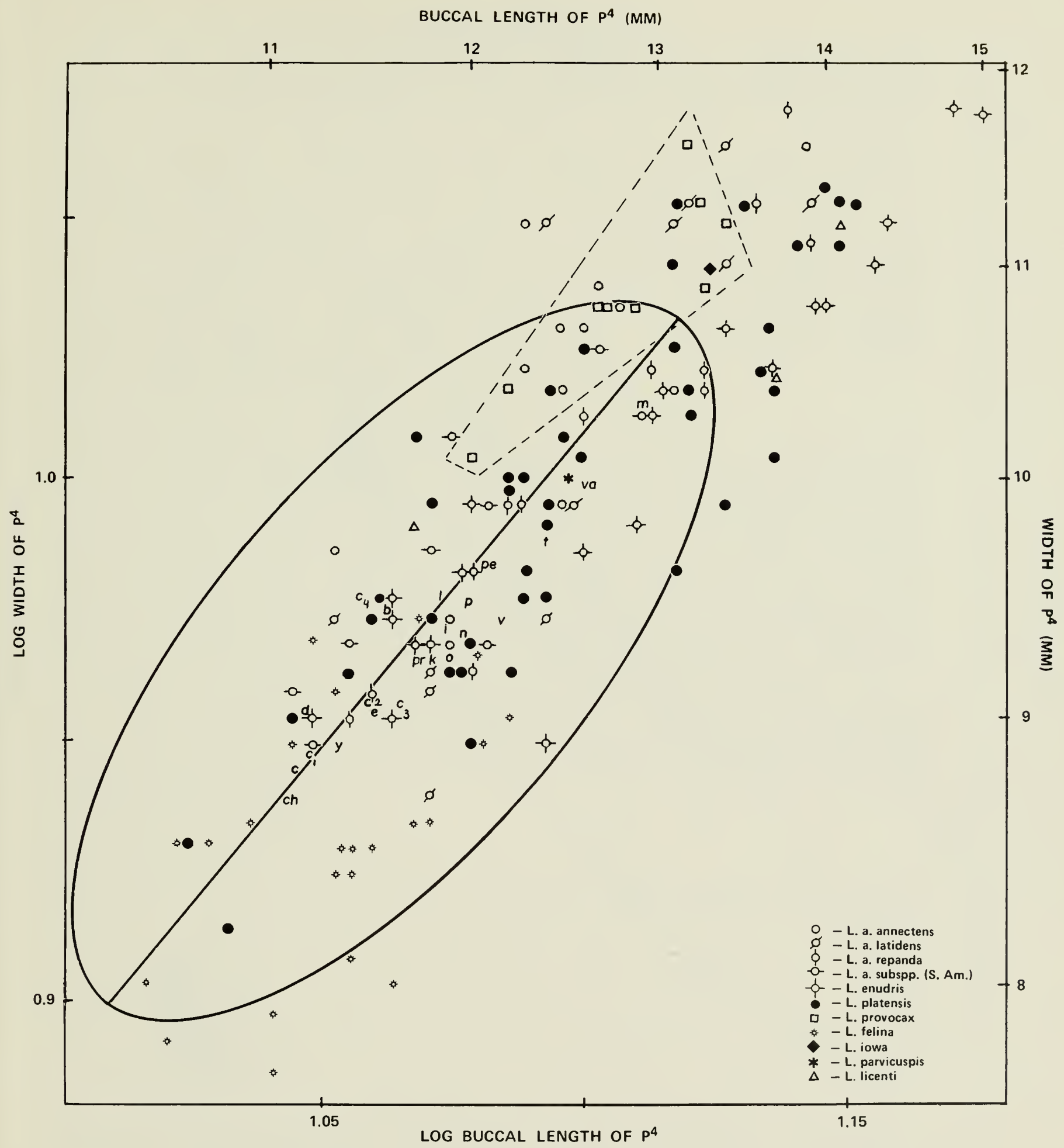

Fig. 9. Covariation between width and buccal length of $\mathrm{P}^{4}$. Slope for L. canadensis frequency ellipse is 1.21 (95\% conf. limits, $1.06-1.39 ; \mathrm{r}=0.70)$.

the intraspecific pattern was not observed in any of the subspecies of L. canadensis.

Width and buccal length of $P^{4}$ (Fig. 9)

All large Neotropical otters have a larger $\mathrm{P}^{4}$ than $L$. canadensis, but the width-length proportion is similar. In $L$. provocax the upper carnassial is somewhat longer and wider than in L. canadensis. In L. felina the opposite is true, the upper carnassial being less broad. The allometric trend for all species is approximately the same, and moreover at the infraspecific level in L. canadensis, no striking divergence from the general trend is evident. 


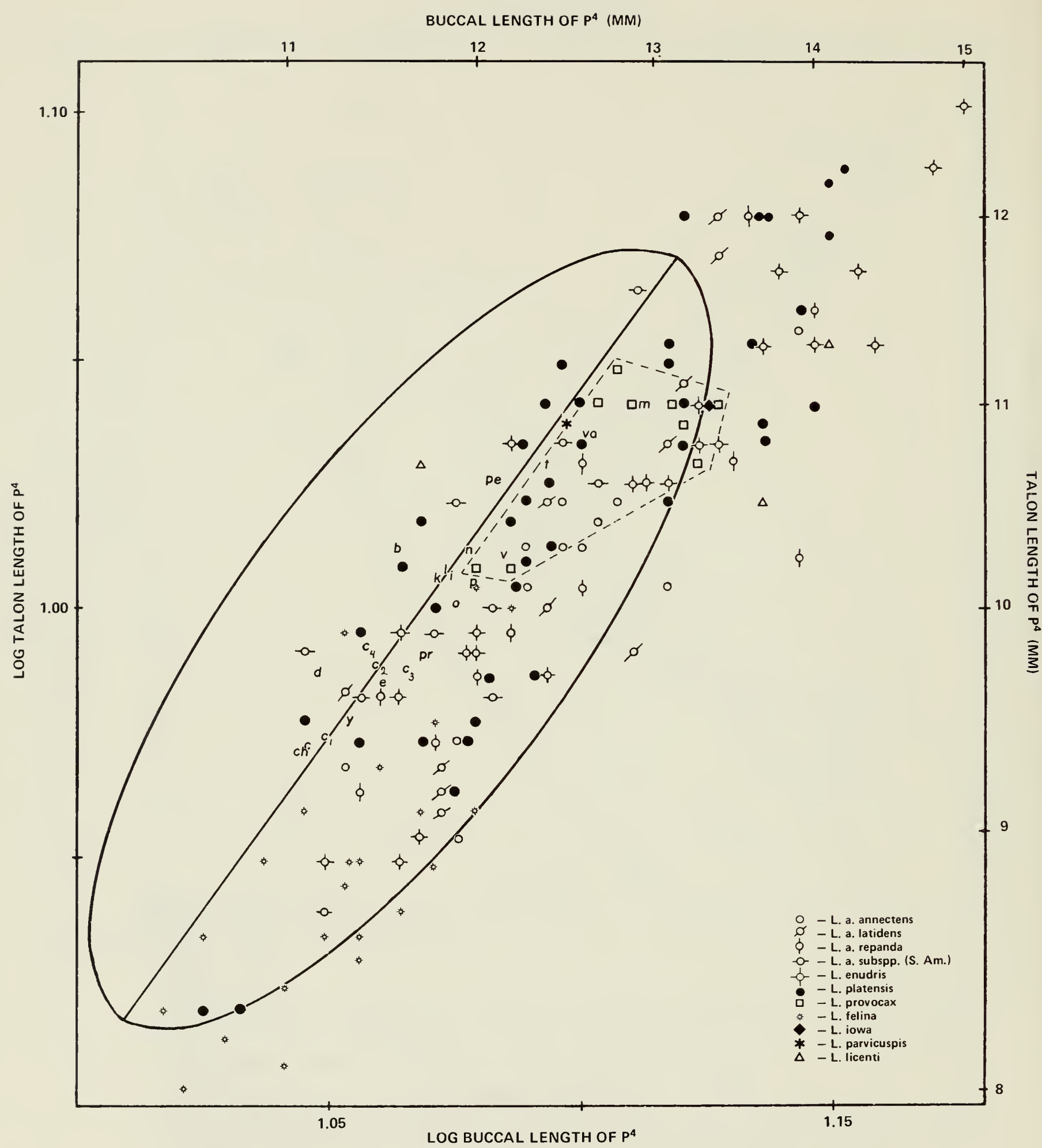

Fig. 10. Covariation between talon length and buccal length of $\mathrm{P}^{4}$. Slope for $L$. canadensis is 1.04 (95\% conf. limits, $1.25-1.56 ; \mathrm{r}=0.77$ ).

Talon length and buccal length of $P^{4}$ (Fig. 10)

The bivariate distribution of $L$. canadensis indicates a shorter $\mathrm{P}^{4}$, with a relatively more expanded talon than in the Neotropical otters. The overlap is considerable, as in most of the relationships examined thus far the allometric trend is approximately the same for all species. Of the subspecies of L. canadensis, mira and brevipilosus are the most divergent, the former having a shorter and the latter a greater talon length. 


\section{Lingual length and greatest diameter of $M^{1}$ (Fig. 11)}

The ellipse representing the bivariate distribution for $L$. canadensis lies above the bivariate distribution of most Neotropical forms. Only the points for $L$. provocax cluster along the canadensis axis. $\mathrm{M}^{1}$ in $L$. provocax is larger than in $L$. canadensis, but the expansion of the talon is similar, whereas in all other Neotropical otters the talon is less expanded. None of the slopes of the samples tested proved to be significantly different.

Of the subspecies of $L$. canadensis, L. c. texensis, L. C. interior and $L$. c. brevipilosus show the smallest lingual lengths of $\mathrm{M}^{1}$ relative to the greatest diameter; L. c. periclyzomae, L. c. vancouverensis and L. c. canadensis (Maritimes-New England sample) show relatively greater lingual length of $\mathrm{M}^{1}$ than the general trend would indicate.

Buccal length of $M^{1}$ and greatest diameter of $M^{1}$ (Fig. 12)

The location of the points for the Neotropical otters lies generally below the canadensis trend line; hence, they have a smaller buccal length relative to the greatest diameter. L. provocax lies well below the canadensis trend line in contrast to the previous relationship (Fig. 11) in which it resembled $L$. canadensis. This combination of relationships corresponds to a tooth that is strongly bucco-lingually expanded. In the other Neotropical otters the tooth tends to be rectangular and uniformly narrower than the same tooth in L. canadensis, in which it approaches the shape of a square.

Within L. canadensis, the subspecies L. c. mira, L. c. periclyzomae and $L$. $c$. nexa have greater buccal lengths than the general trend would indicate, whereas the subspecies $L$. c. lataxina and $L$. c. interior have relatively smaller buccal lengths.

Width and length of $M_{1}$ (Fig. 13)

In this relationship the bivariate distributions form four relatively distinct groups: L. felina well below the canadensis axis; L. annectens, L. enudris and $L$. platensis predominantly below the canadensis axis, $L$. canadensis and finally $L$. provocax predominantly above the canadensis axis. L. felina has a narrower $M_{1}$ than that of any other in the group. The trigonid as well as the talonid, which does not possess an expanded buccal cingulum, are narrower. The tooth in L. annectens, L. enudris and L. platensis is similar to that of $L$. canadensis, evidenced by the degree of overlap in their distributions, but it tends to have a less expanded buccal cingulum at the talonid. In L. provocax the entire tooth is broad and has a well developed buccal cingulum, and it is also relatively larger than that of most other forms (see Fig. 18 B).

At the infraspecific level, L.c. canadensis (New England sample) and L. c. optiva have the most narrow $\mathrm{M}_{1}$ and $L$. c. brevipilosus the most broad.

\section{Length of $M_{1}$ and length of the lower P-M series (Fig. 14)}

In this relationship three clusters were distinguished. L. felina has the longest $\mathrm{M}_{1}$ relative to the molar-premolar series. L. annectens, L. enudris, $L$. platensis and $L$. provocax also have a long $\mathrm{M}_{1}$ relative to the molarpremolar series, and $L$. canadensis has the shortest $M_{1}$ relative to the tooth row. 


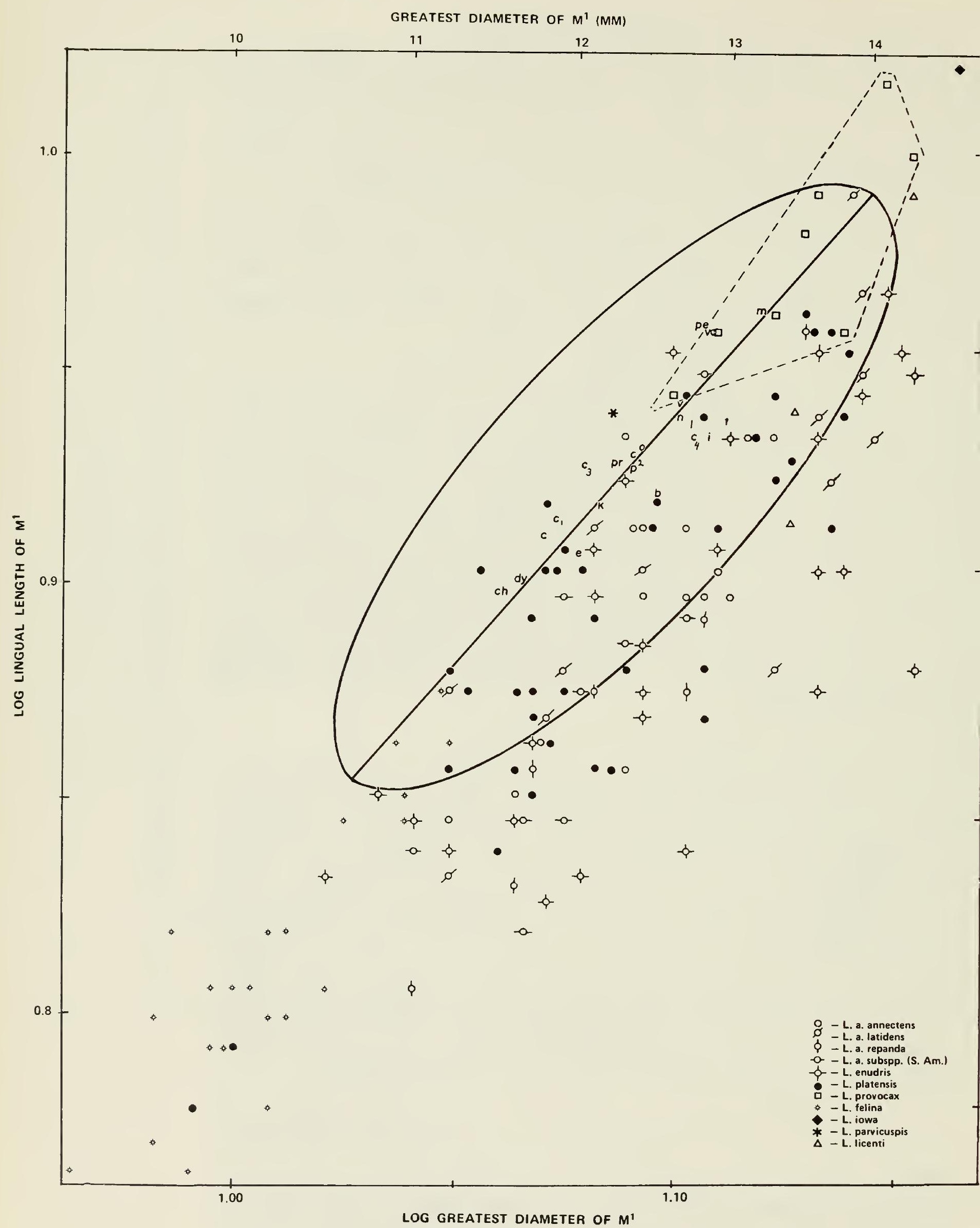

Fig. 11. Covariation between lingual length and greatest diameter of $\mathbf{M}^{1}$. Slope for L. canadensis is 1.15 (95\% conf. limits, $1.04-1.27 ; \mathrm{r}=0.79$ ). 


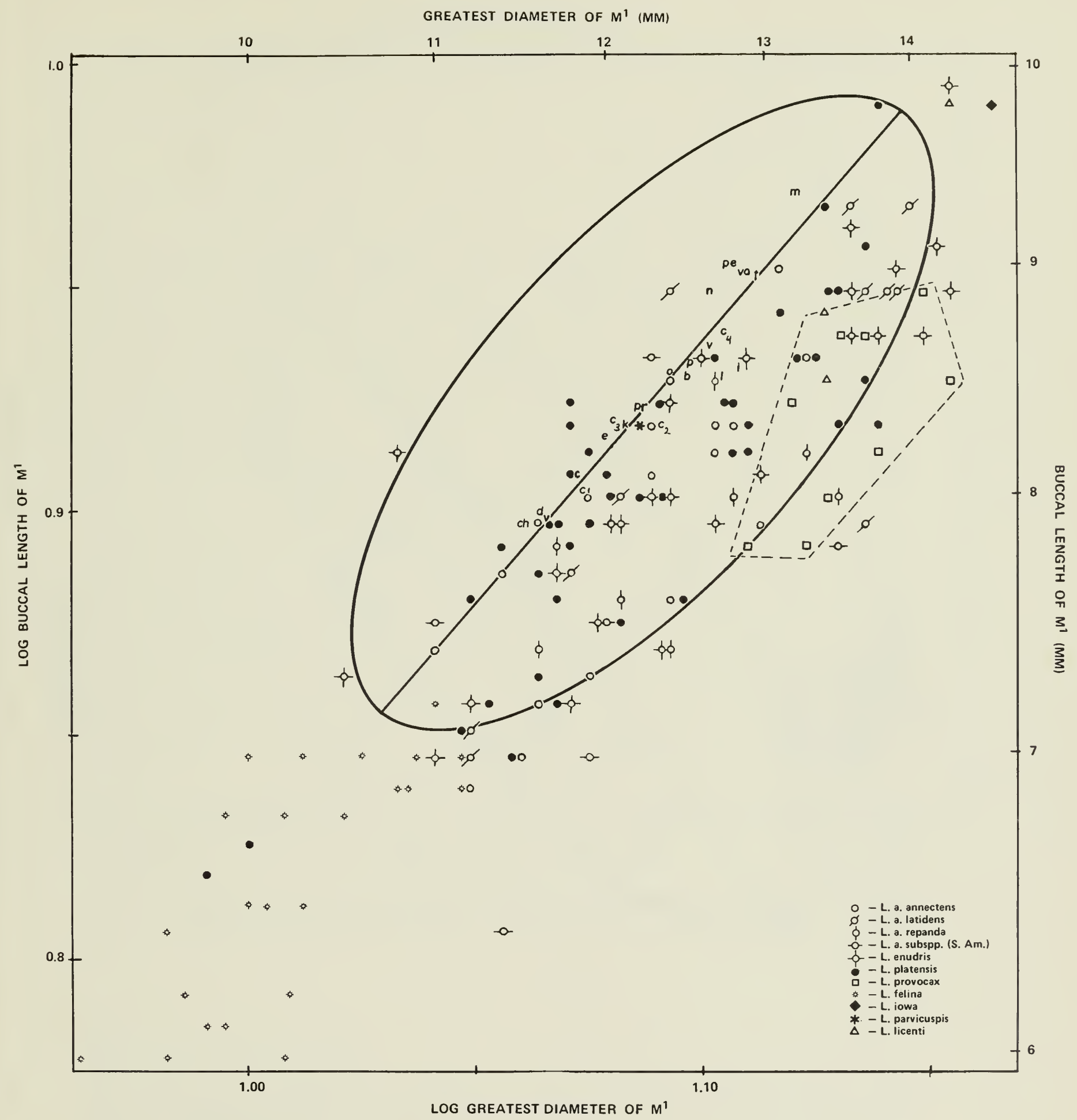

Fig. 12. Covariation between buccal length and greatest diameter of $\mathbf{M}^{1}$. Slope for L. canadensis is $1.16(95 \%$ conf. limits, $1.01-1.33 ; \mathrm{r}==0.70)$.

L. c. lataxina, L. c. vaga and $L$. c. texensis are characterized by a relatively long $M_{1}$ in relation to the molar-premolar series. A tendency towards a long $M_{1}$ is found to a somewhat lesser extent in the northern New York, Michigan and Maritimes-New England samples of L. c. canadensis. 


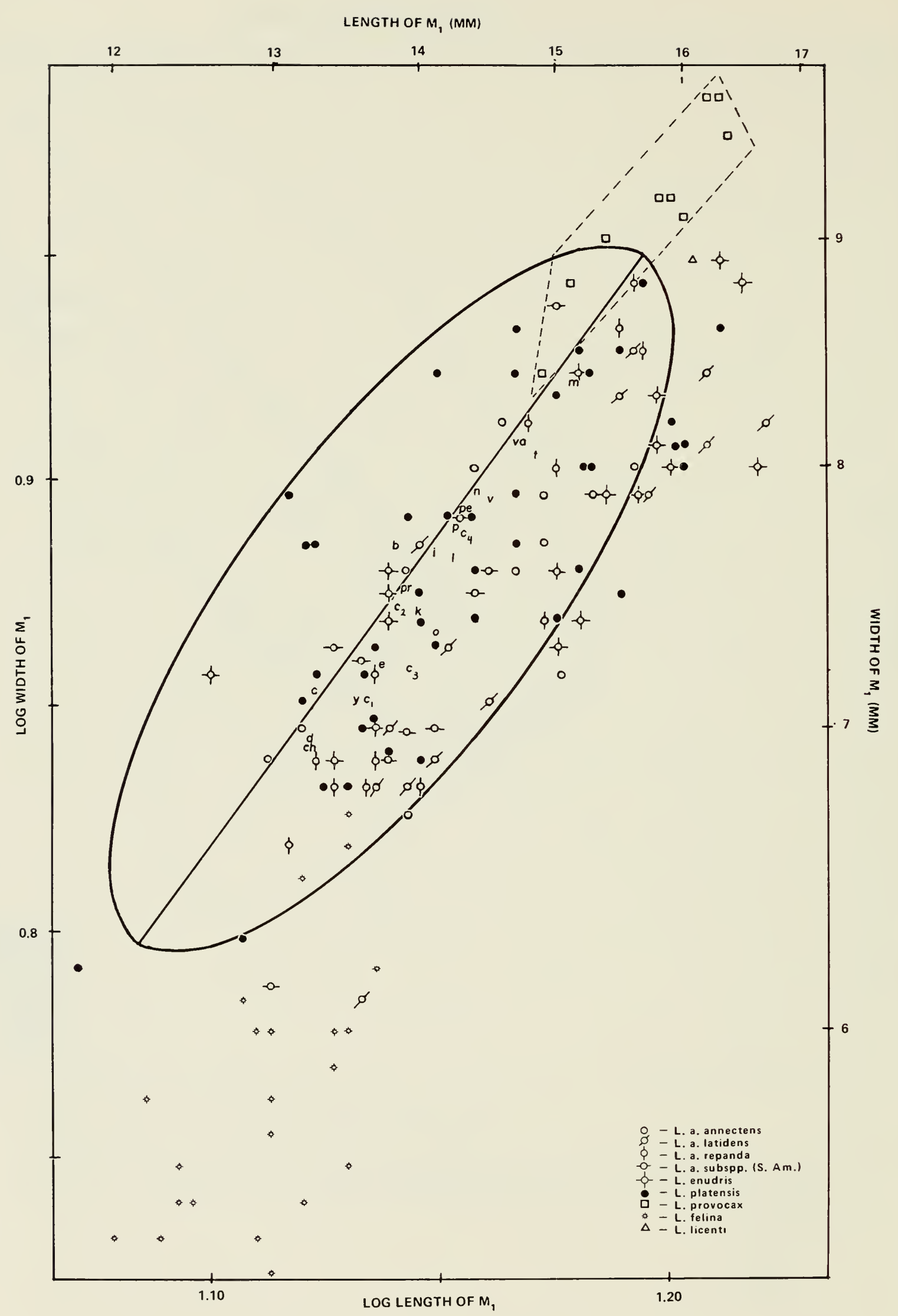

Fig. 13. Covariation between width and length of $\mathbf{M}_{1}$. The slope for $L$. cancudensis is 1.39 ( $95 \%$ conf. limits, $1.25-1.56 ; \mathrm{r}=0.77)$. 


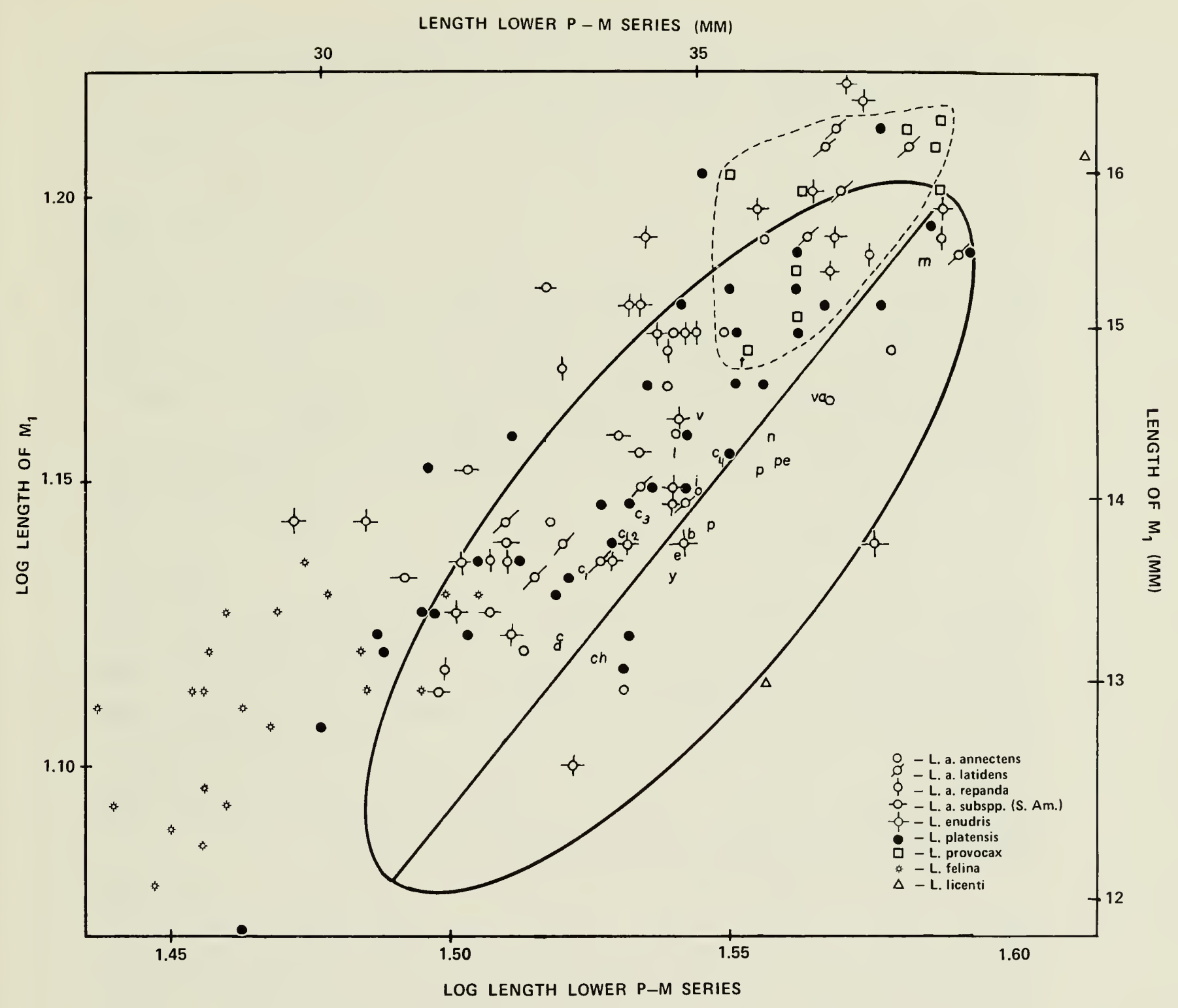

Fig. 14. Covariation of length of $M_{1}$ and length of premolar-molar series. The slope for $L$. canadensis is 1.22 (95\% conf. limits, $1.09-1.37 ; \mathrm{r}=0.77$ ).

\section{DISCUSSION AND SUMMARY}

The preceding examples of bivariate relationships of the skull and teeth show that size-dependent changes in proportion occur. Of all the characters investigated, including those discussed elsewhere (van Zyll de Jong, 1968), only two, the width of the postorbital constriction and the height of the tympanic bullae, appear to vary independently of size.

Interorbital width, orbito-nasal length, mastoid width, talon length of $\mathrm{P}^{4}$ relative to the buccal length, lingual and buccal length of $\mathrm{M}^{1}$ relative to its greatest diameter, and the length of $M_{1}$ relative to the molar-premolar series tend to be larger in large individuals of the same species. Basal skull width, width of the braincase, and height of the cranium, not discussed here. are related to size by negative allometry and tend to be smaller in large specimens. Palatal length, length of the $\mathrm{M}_{1}$ and $\mathrm{P}^{+}$relative to overall size, width of $\mathrm{P}^{4}$ relative to its buccal length, and width of $\mathrm{M}_{1}$ relative to its length, are approximately isometric. 
Allometric trends for the bivariate relationships investigated have approximately the same slope for all taxa. Bivariate distributions of the different forms differ mainly in that they do not lie along the same allometric regression. Distributions overlap in all relationships investigated. Because of its inferior size, L. felina overlaps the larger forms to a lesser degree than these overlap with one another. If the scatter of the annectensenudris-platensis group appear greater than that of L. canadensis, this will be due partly to the greater degree of sexual dimorphism and partly because the specimens of $L$. canadensis are represented by a $95 \%$ frequency ellipse.

The relatively minor differences and the apparent absence of greatly divergent trends indicate that we are dealing with closely related forms in which the shape of the skull and teeth have differentiated little.

Some of the differences in shape and proportion of the skull and dentition in the different taxa, other than those resulting from differences in size, can now be summarized. In general, four groups were detected on the basis of their distinct bivariate distributions. These correspond to L. canadensis, the annectens-enudris-platensis group, L. provocax and L. felina. The most distinct is $L$. felina, whereas $L$. canadensis and the large Neotropical forms are more similar. L. annectens, L. enudris, L. platensis and L. provocax constitute a relatively compact group with greatly overlapping bivariate distributions. Most distinct in this group of the large Neotropical forms is L. provocax. In many of the bivariate relationships it has the most divergent distribution and in some it is as radically different from the other larger Neotropical forms as they are from $L$. canadensis.

L. canadensis differs from all Neotropical forms in its greater orbito-nasal length, smaller mastoid width, smaller lower carnassial relative to the premolar-molar series, greater talon length of the $\mathrm{P}^{4}$ relative to its buccal length. L. canadensis differs from the Neotropical forms, with the exception of L. felina, in its greater width of the postorbital constriction. It differs from the Neotropical forms excluding L. provocax in its longer palate, and a somewhat broader $\mathrm{M}_{1}$. The tympanic bullae of $L$. canadensis are flatter than those of the annectens-enudris-platensis group.

L. annectens, L. enudris and L. platensis differ little among themselves. L. enudris has a smaller mastoid width, and larger $\mathrm{M}_{1}$ and $\mathrm{P}^{4}$ and a smaller lingual length of the $\mathrm{M}^{1}$ than $L$. annectens and L. platensis.

L. provocax, although most similar to the other large Neotropical otters in its bivariate distributions, differs from them to a larger degree than they do among themselves. It has a longer orbito-nasal length, longer palatal length, broader $\mathrm{P}^{4}$ and $\mathrm{M}_{1}$ and lingual length of the $\mathrm{M}^{1}$ much greater than its buccal length.

L. felina differs from all other forms by greater width of the postorbital constriction, greater length of the $\mathbf{M}_{1}$, which is also narrower, greater buccal length of $\mathrm{P}^{4}$, which has a smaller width and shorter talon length.

As to the subspecies samples of L. canadensis, it is evident from a perusal of the distribution of their means that there is a tendency for the means of neighbouring subspecies to cluster together and to show similar deviations from the intraspecific axis. However, a clear impression of the similarity of the different subspecies to one another for all the different 
characters compared is not easily obtained from the graphs. The similarities of the different subspecies and the question of their taxonomic validity are pursued further in the section dealing with the estimation of overall similarity.

\section{Other Characters}

I compared a number of other characters, chiefly non-numerical. The majority of the observations were based on smaller samples than was the case in the allometric analysis; however they add further information and, considered in conjunction with the results of the numerical analysis, provide a broader foundation on which taxonomic conclusions can be based. Only those characters that were found to vary from one form to another are discussed.

\section{SKULL BONES}

The shape of the bones making up the skull could be compared in a number of juvenile skulls in which the sutures had not yet fused. Obvious differences in shape were found in the frontals, the nasals, the palatines, and the jugal-maxillary boundary. Most of these differences are illustrated in Figs. 15 and 16.

The frontals project only slightly, or not at all, into the parietals in L. canadensis, L. annectens, L. platensis and L. felina. In L. provocax the frontals projected sharply into the parietals (one specimen available; see Fig. 16 A).

The nasals show a greater variation of shape in different forms. In $L$. canadensis they are rounded posteriorly and extend beyond the maxillae; they widen only slightly and gradually anteriorly. In L. annectens the nasals are shorter, with a broadly rounded posterior tip, have a distinct constriction in the middle and flare moderately at the anterior end (Fig. 15 B). The nasals extend beyond the maxillae.

In one juvenile skull of $L$. enudris, the nasals are similar to L. canadensis, lacking the constriction in the middle as observed in L. annectens. The nasals are long, the outer edges running parallel, flaring only slightly anteriorly; the posterior tip is rounded. In one specimen from Bolivia the nasals are mushroom-shaped (Fig. $16 \mathrm{C}$ ), resembling somewhat those of L. annectens but with the posterior end flatter and the bones much shorter, extending only slightly beyond the maxillae. The shape of the nasals in L. platensis is similar to those of L. enudris and L. canadensis, but they appear somewhat shorter. They extend slightly beyond the maxillae. The nasals of $L$. provocax are long, with nearly parallel outer edges; their posterior ends are somewhat rounded, and their anterior ends flare strongly. The nasals of $L$. felina are short, not extending beyond the maxillaries, the outer edges parallel and not flaring anteriorly, and the posterior tip has the shape of a stretched-out M (Fig. 16 B).

The jugal differs in the different forms in the extent to which it contributes to the bar enclosing the infraorbital foramen. In $L$. canadensis the jugals extend across the infraorbital foramen almost to the lacrimal bone. 


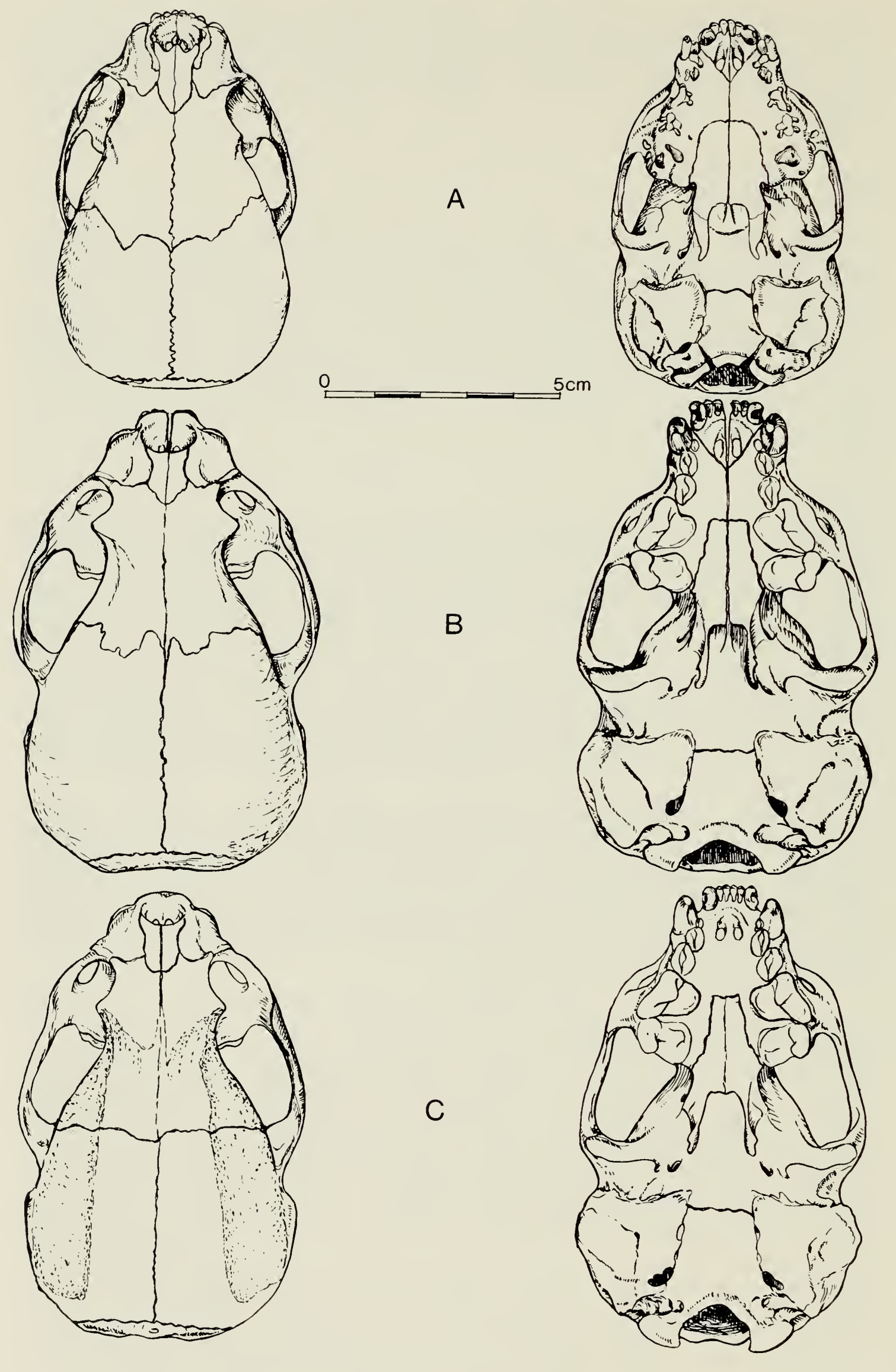

Fig. 15. Dorsal and ventral views of juvenile otter skulls. A. L. canadensis (ROM 3573). B. L. annectens (SNMH 11/9). C. L. platensis (ANSP 4675). 

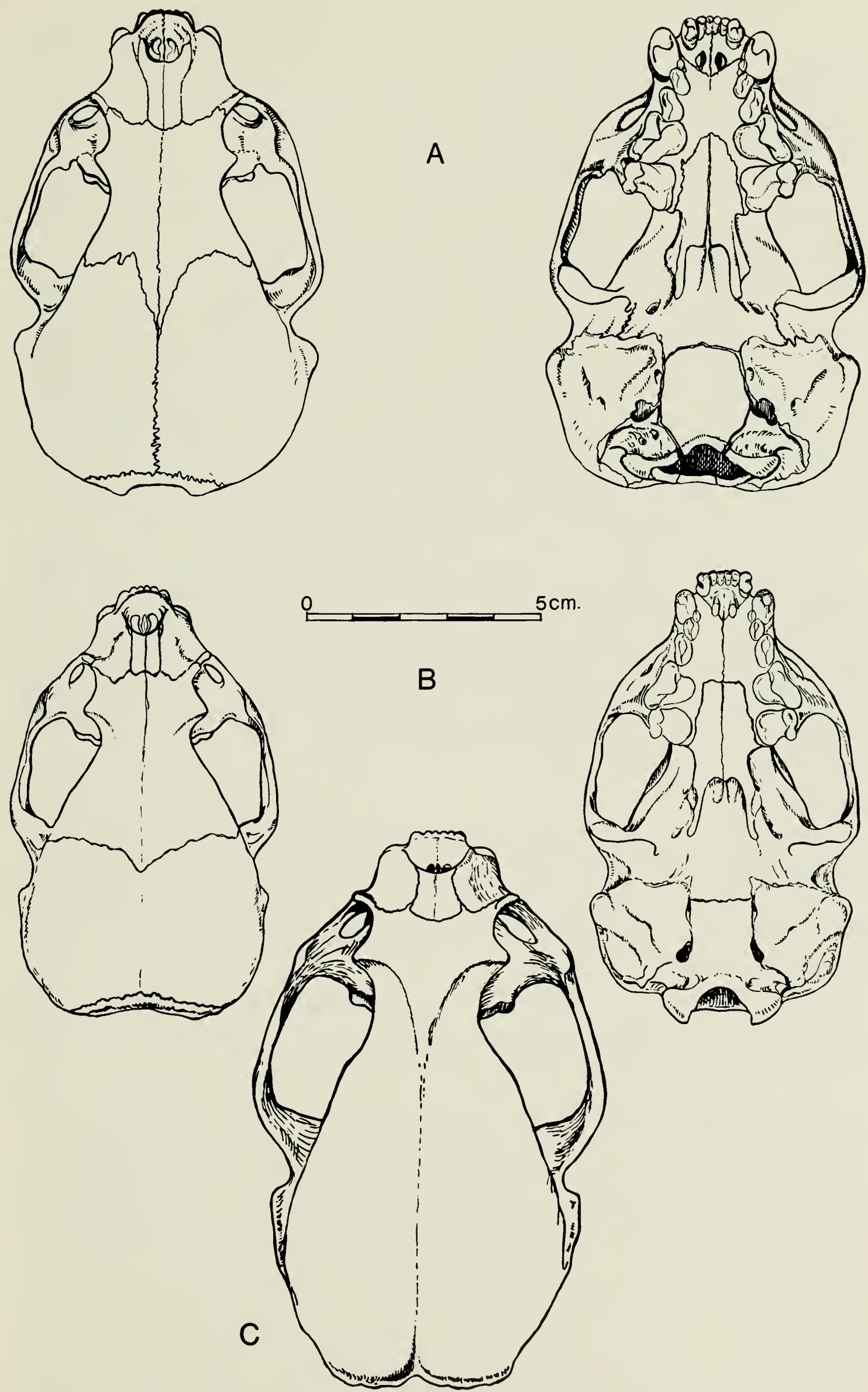

Fig. 16. Dorsal and ventral views of juvenile otter skulls. A. L. provocole (BM 3-827-6). B. L. felina (IRSB 1115). C. L. emulris (SMNH 3481). 
In $L$. annectens and $L$. provocax the jugal stretches only approximately half way across. The condition in L. platensis is similar to that of $L$. canadensis. No observations on this character could be made for L. enudris. The most dissimilar condition was seen in L. felina, in which the jugals did not extend across the infraorbital foramen.

Finally, the palatine bones display a number of characteristic differences in shape. In $L$. canadensis they are broad, the outer margins forming a broadly rounded arch (Fig. $15 \mathrm{~A}$ ). The palatines of $L$. annectens have more tapering sides with a square anterior margin (Fig. 15 B). L. enudris and L. platensis (Fig. $15 \mathrm{C}$ ) have palatines similarly shaped but one specimen of $L$. platensis was more like $L$. canadensis in that the anterior margins were rounded. L. provocax (Fig. 16 A) has palatines that taper anteriorly as in annectens and enudris, but the apex is rounded and not square. The posterior edge of the palate in L. provocax is further characterized by two small projections on either side of the median suture, which are present in all skulls examined, adult and juvenile (see also Fig. 27 A, B). The palatines of $L$. felina taper anteriorly and are square tipped (Fig. $16 \mathrm{~B}$ ).

In large adult skulls the lambdoidal crest is well developed, whereas the sagittal crest is weak and scarcely a low ridge. In L. canadensis the lambdoidal crest curves up, whereas in the large Neotropical forms the crest projects caudad in a roof-like manner. The lambdoidal crest continues to the mastoid processes, which tend to extend laterally in the large Neotropical forms, in particular in L. annectens and L. provocax, but which extend ventrally in L. canadensis.

\section{DENTITION}

In some taxa the teeth display constant differences in topography. These differences are most distinct in $\mathrm{P}^{4}, \mathrm{M}^{1}$ and $\mathrm{M}_{1}$, and the following discussion is centered chiefly around these. Characteristic features of the upper and lower dentitions for all species in the group as well as other otters are illustrated in Figs. 17-20.

$\mathrm{P}_{4}$ usually has an accessory posterior cuspule in all forms of the American group that varies from a weak indication to a very distinct cusplet. In a few specimens it was lacking.

In $L$. canadensis the talon of $\mathrm{P}^{4}$ is expanded and usually extends nearly the entire length of the tooth, touching or nearly touching the $\mathrm{M}^{1}$ in most. The outline of the talon, which is widest at the paracone, varies from semicircular to nearly triangular. Usually the occlusal surface of the talon has a depression in its widest part separated by a slightly raised threshold from a smaller depression or flat area posterior to it. In a few specimens in which the talon does not extend very far this feature is lacking. The parastyle, anterior to the paracone, is not prominent, usually lying on a line with the anterior edge of the talon and carrying a small cuspule. The anterior and posterior edges of the paracone continue into the blade-like edge of the metacone. More lingually situated, a second anterior edge of the paracone continues without break into the edge of the talon cingulum.

$\mathrm{M}^{1}$ of $L$. canadensis also has a large talon; the arch-shaped ridge of the protocone is surrounded posteriorly by a flattened shelf-like hypocone that 
is usually greatly expanded posteriorly and by a relatively broad anterior cingulum.

$M_{1}$ is broad. The trigonid is high, with the metaconid slightly lower than the paraconid and protoconid. The talonid is expanded by a broad buccal, basal cingulum, its lingual side has only a very low cingulum and the basin is very shallow. The cutting ridge of the talonid is relatively high and has a small hypoconid.

The basic pattern of the teeth in the Neotropical forms is similar to that described for $L$. canadensis and the descriptions of the teeth of these forms are therefore confined to those features that appear to present constant differences. The dentition of $L$. annectens is very similar to that of $L$. canadensis. The $\mathrm{P}^{4}$ is nearly identical, the occlusal surface of the talon is often simplified to a single continuous U-shaped hollow between the blade and the raised cusplike cingulum at the lingual margin of the talon. The $\mathbf{M}^{1}$ likewise is as in L. canadensis, but in general the hypocone and the cingulum anterior to the protocone are less expanded than in that species. The $\mathrm{M}_{1}$ is also very similar to the same tooth in L. canadensis, but the buccal cingulum is usually less expanded.

The dental topography of $L$. enudris and L. annectens is similar and there do not seem to be any distinct characters in the teeth by which these two forms can be distinguished. The condition of the talon of the $\mathrm{P}^{4}$ is frequently as described for $L$. annectens. The talon of the $\mathrm{M}^{1}$ tends to be slightly expanded giving the entire tooth a slender appearance. This condition is also found in L. annectens, however. The dentition of L. platensis shows the same features as those found in the other Neotropical forms so far discussed; no salient differences were observed.

The characters of the teeth of $L$. provocax are unique and distinguish it readily from other taxa (Fig. $18 \mathrm{~B}$ ). The $\mathrm{P}^{4}$ has a broadly expanded talon, its anterior depression is circular and bowl-shaped, and is surrounded by a relatively broad, rounded rim. A smaller and shallower depression lies posterior to it; the two depressions are separated by a raised area. The $\mathrm{M}^{1}$ has an expanded anterior cingulum; the hypocone is also expanded. The $M_{1}$ is very broad and the talonid has a very broad buccal cingulum, which makes the cutting ridge seem low. The cingula of all these teeth tend to be crenulated.

L. felina (Fig. $18 \mathrm{C}$ ) also has a clearly differentiated dentition. The $\mathrm{P}^{4}$ has a prominent parastyle, which is free from the talon. The posterior outline of the talon is relatively straight and there is a gap between it and the $\mathrm{M}^{1}$. The occlusal outline of the talon has the shape of a $\mathrm{J}$, with the left side representing the anterior edge of the talon. The $\mathrm{M}^{1}$ is narrower mesiodistally due to a relatively narrow anterior cingulum; the hypocone is also relatively little expanded. The entire tooth looks rather curved because of the curved protoconal ridge and the curved posterior outline of the tooth running parallel to it. In the mandible the $M_{1}$ is noticeably narrower than the same tooth in any of the other forms; the buccal cingulum of the talonid is quite narrow.

In addition to the differences outlined, Pohle (1920) stated that older specimens of $L$. felina lack the $\mathrm{P}^{1}$. In the present study the $\mathrm{P}^{1}$ was found 


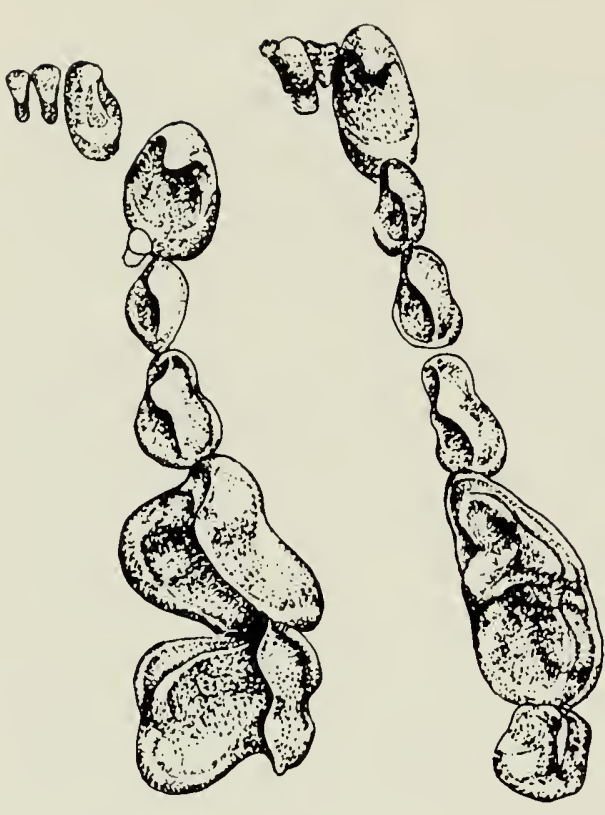

A

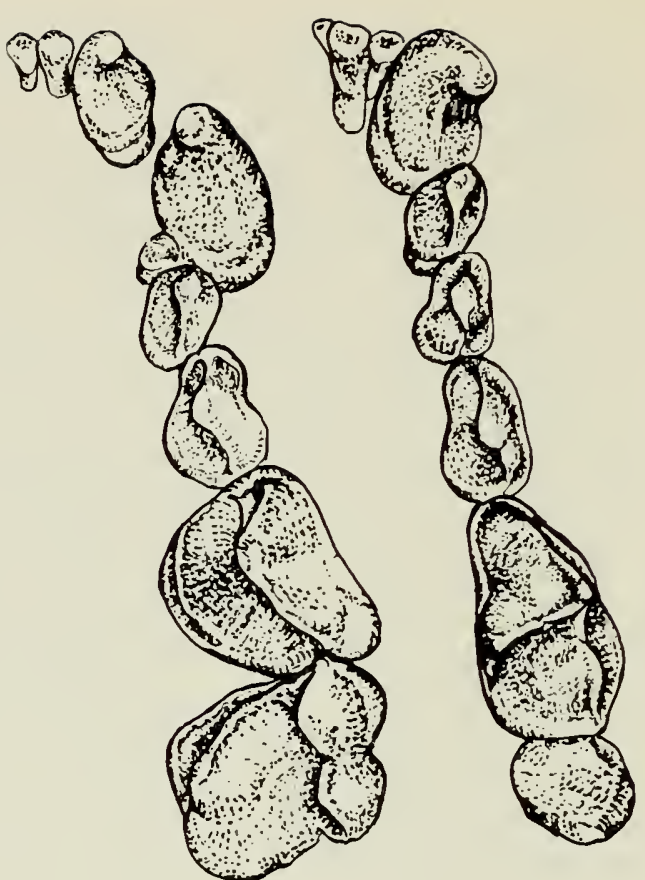

$B$

0

$5 \mathrm{~cm}$.
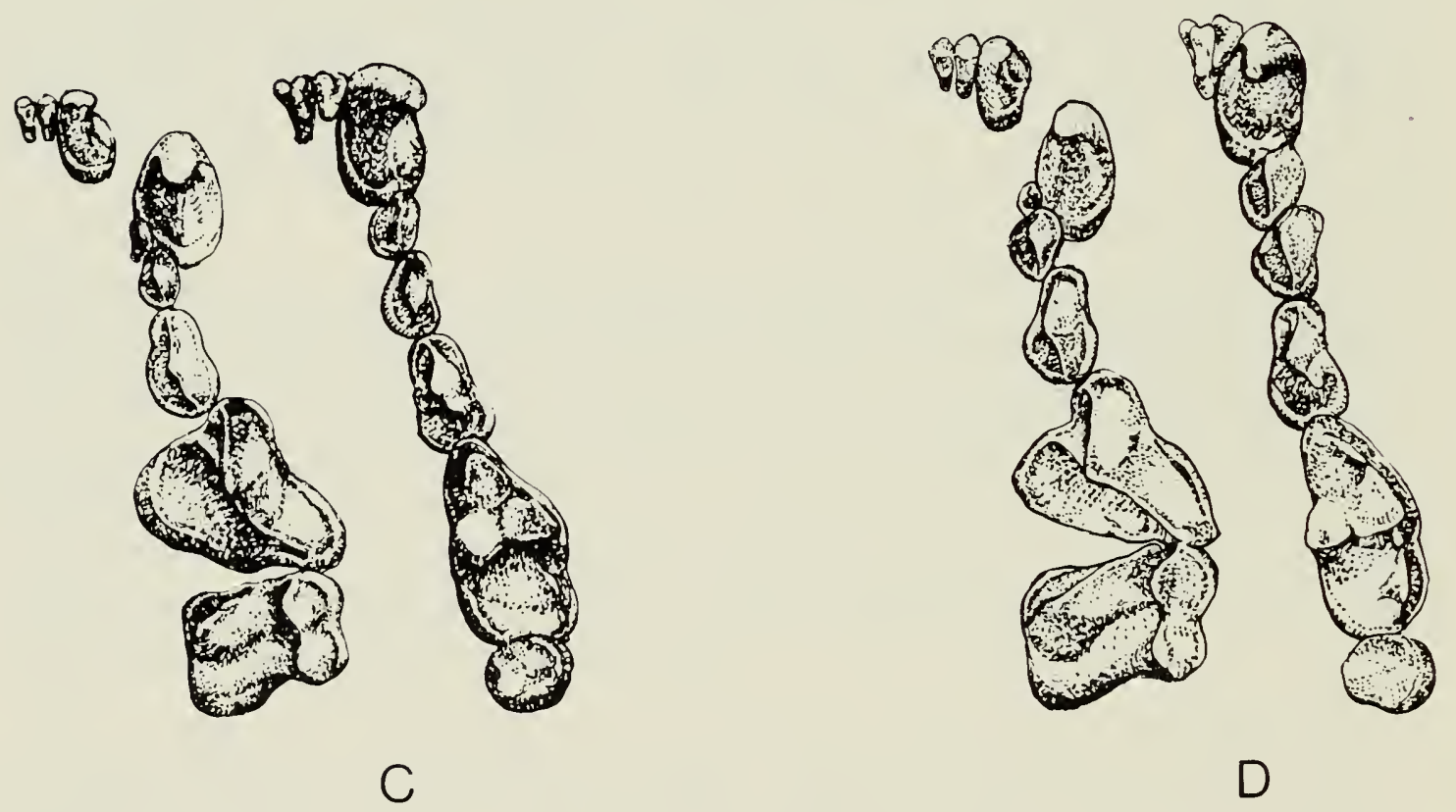

D

Fig. 17. Occlusal view of upper and lower toothrows; approximately life size. A. L. canadensis adult of from Ontario (ROM 16652). B. L. canadensis adult $0^{7}$ from the Pacific coast of British Columbia (BCPM 1865). C. L. annectens (CAS 9159) adult 9 . D. L. enudris subadult $q$ (Rом 32326). 


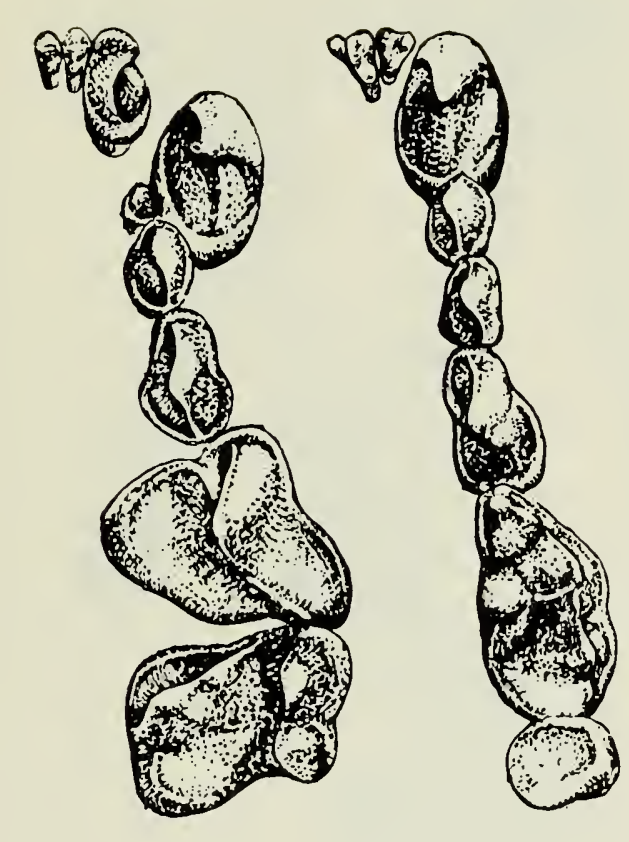

A

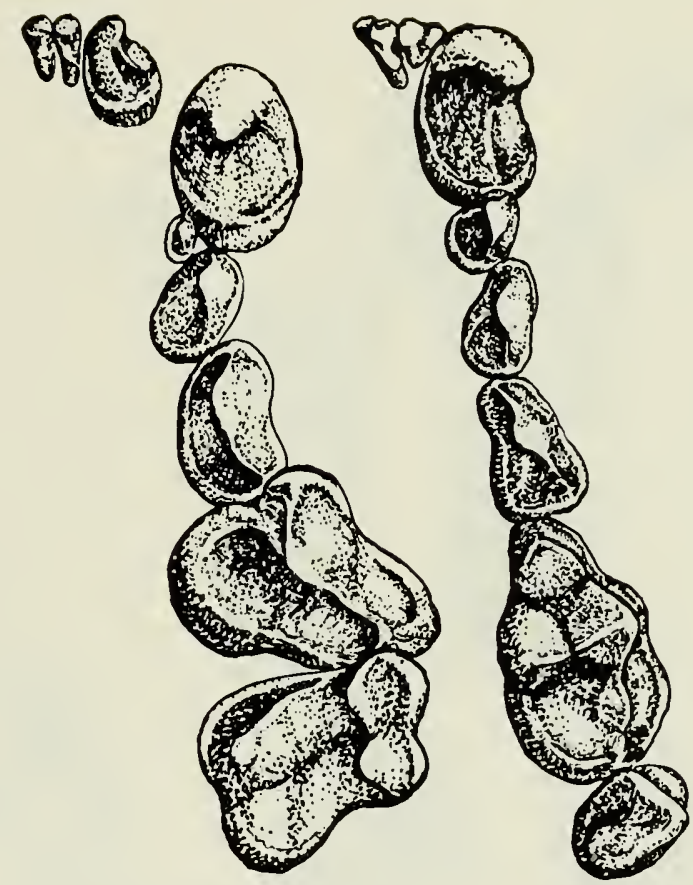

B

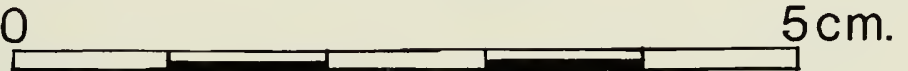

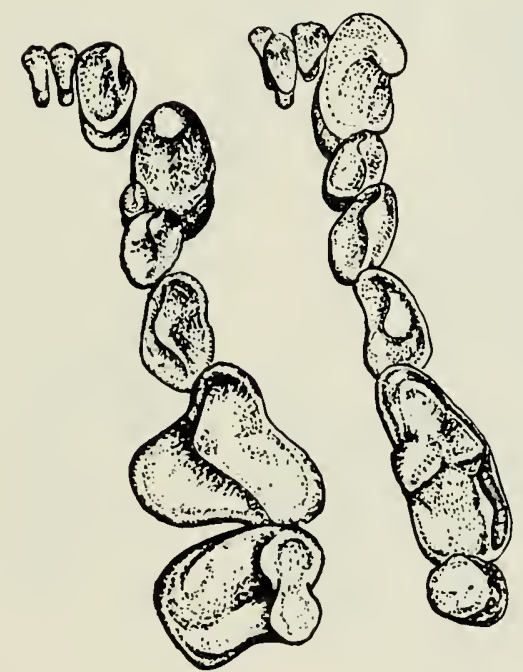

C

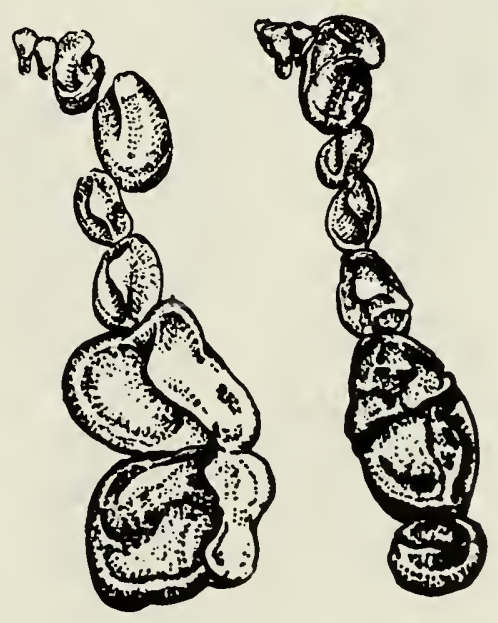

D

Fig. 18. Occlusal view of upper and lower dentitions; approximately life size. A. L. platensis based on Pohle (1920) and several actual specimens. B. L. provocax adult sex unknown (NMFis 146). C. L. felina adult or (FMNH 24223). D. Amblomix cinerea adult, sex unknown (FMNH 88611). 


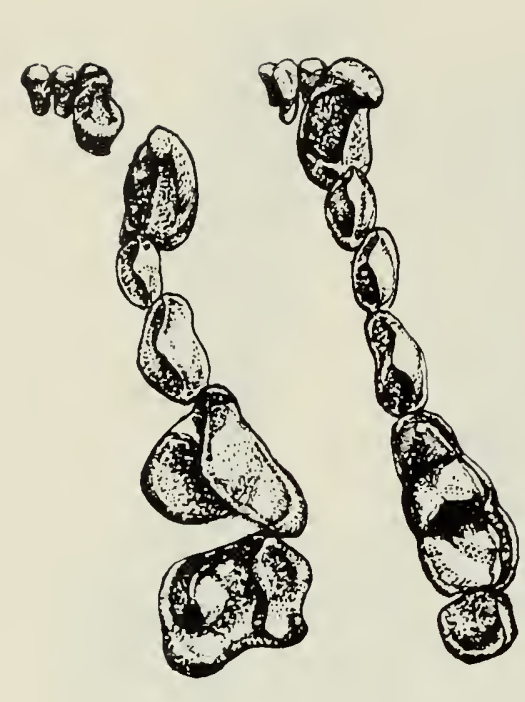

A

0

C
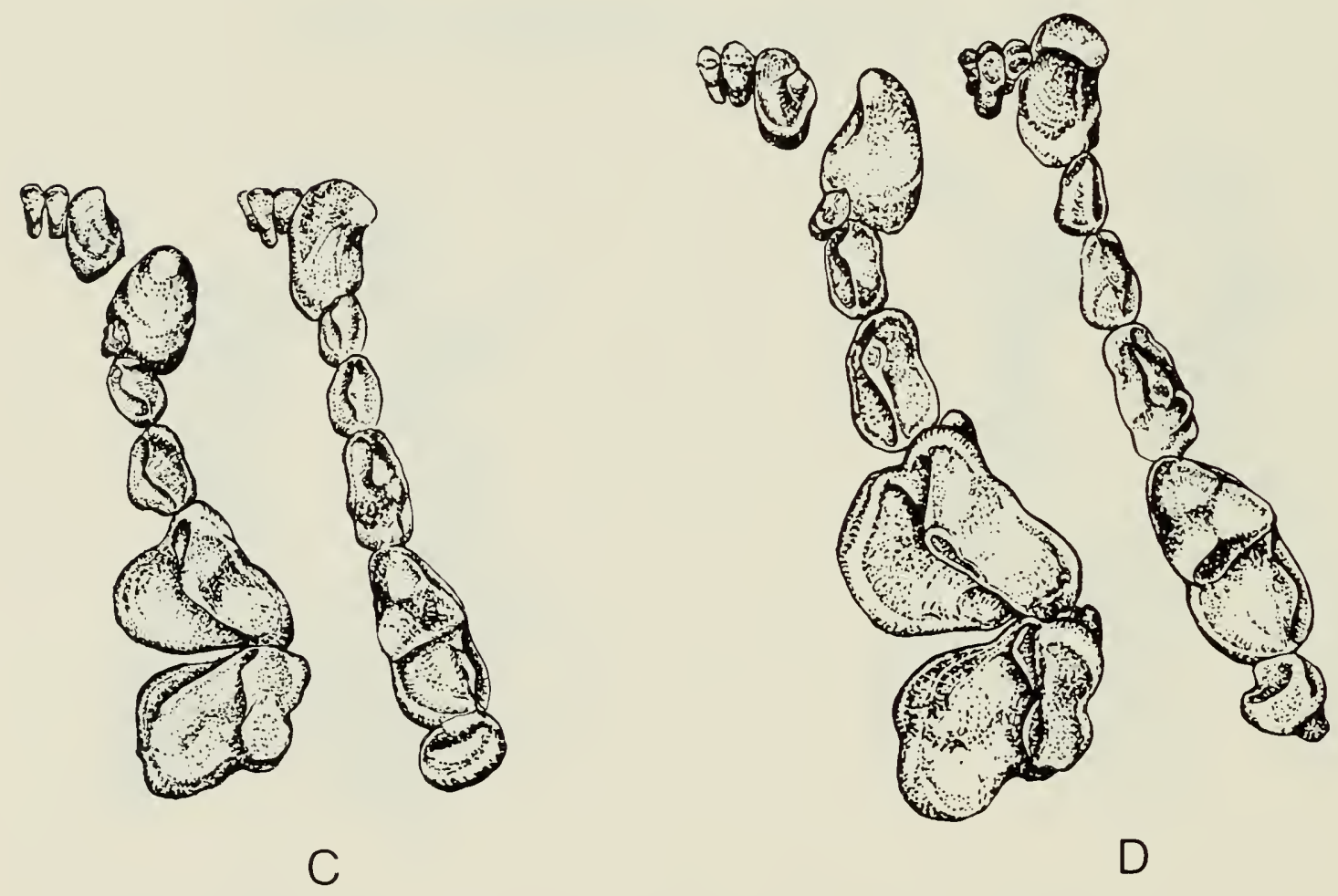

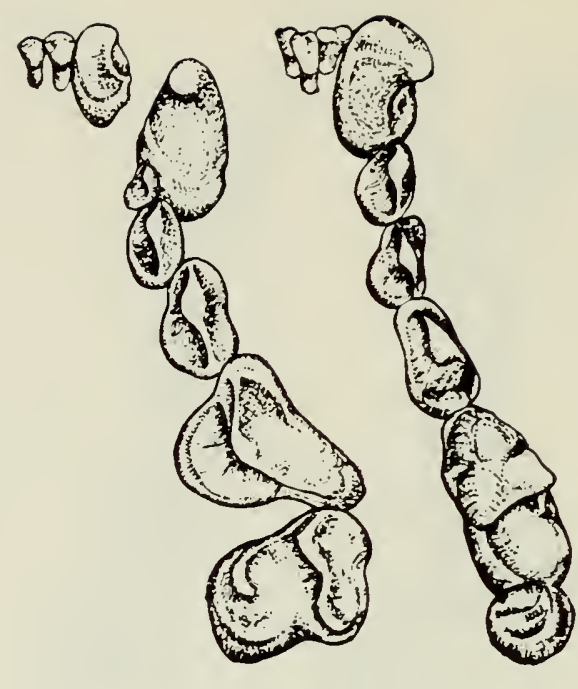

B

Fig. 19. Occlusal view of upper and lower dentitions; approximately life size. A. L. lutra barang young, sex unknown (ANSP 20234). B. L. sumatrana o (ZM CN4494). C. L. maculicollis adult, sex unknown (IRSB 4198). D. Lutrogale perspicillata adult of (ZM CN4496). 

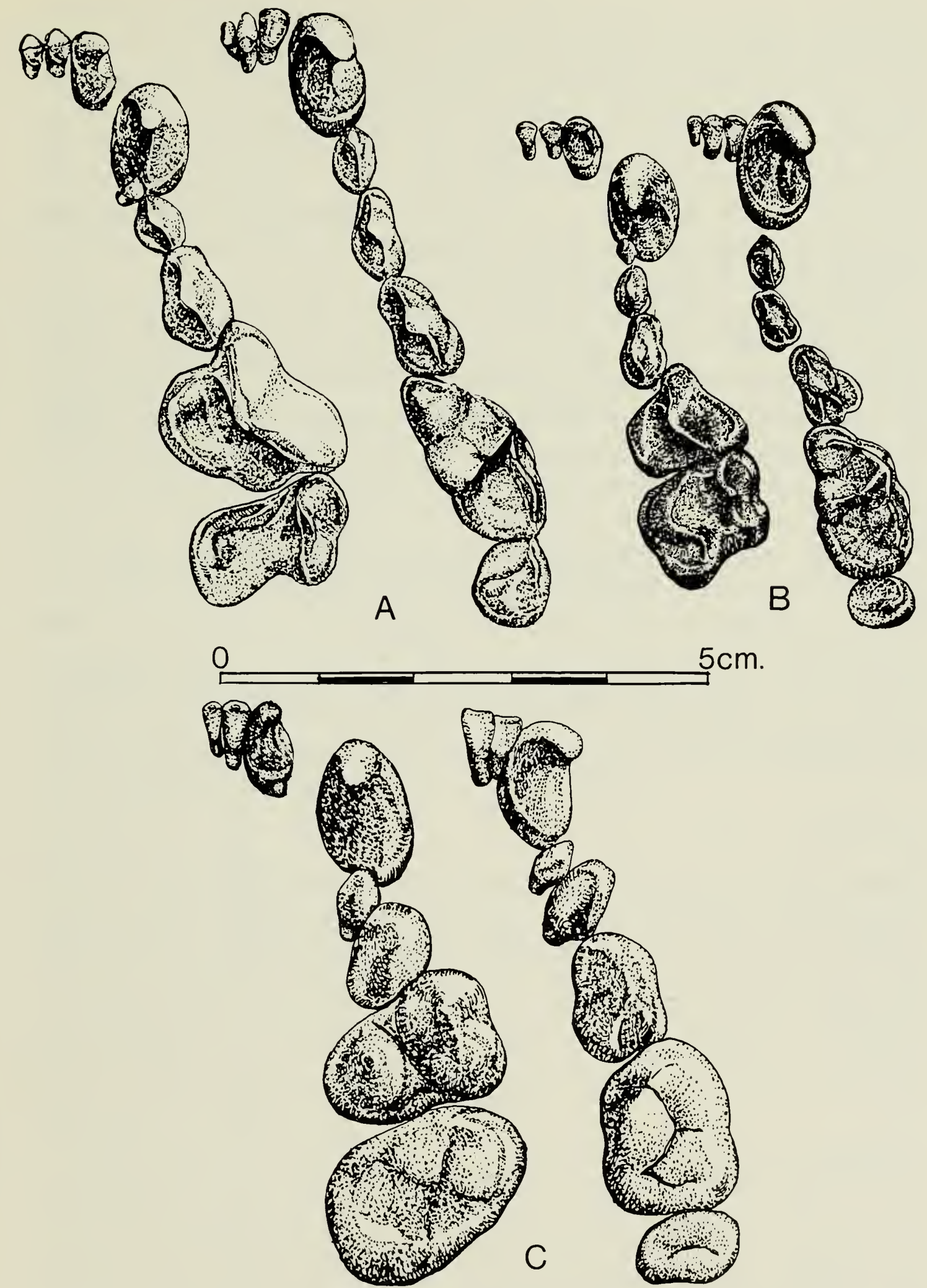

Fig. 20. Occlusal view of upper and lower dentitions; approximately life size. A. Pteronura brasiliensis adult o (ROM 32260). B. Aony'x capensis adult $q$ (RON 38431). C. Enlyydra lutris adult ơ (ROM 25350). 
in adult as well as juvenile skulls, but the frequency at which this tooth is present is much lower than in the other forms. In the sample examined $(\mathrm{N}=23), 39 \%$ possessed the $\mathrm{P}^{1}$ bilaterally, in $17 \%$ it was present unilaterally and in $44 \%$ the tooth was entirely lacking. In $L$. canadensis, L. annectens, L. enudris, L. platensis and L. provocax this tooth was present in both sides in 97\% $(\mathrm{N}=591), 95 \%(\mathrm{~N}=44), 93 \%(\mathrm{~N}=28)$, $95 \%(\mathrm{~N}=44)$ and $80 \%(\mathrm{~N}=10)$ of the samples. The $\mathrm{P}^{1}$ is a vestigial tooth, and in some genera of the subfamily (Amblonyx, Fig. $18 \mathrm{D}$ and Enhydra, Fig. $20 \mathrm{C}$ ) it is lacking as a rule.

The deciduous dentition could be compared in a small number of skulls of $L$. annectens, L. platensis, L. canadensis and L. felina. Few obvious differences were noted but one specimen of $L$. annectens from Ecuador and a $L$. platensis skull had a distinct posterior cuspule on the lower canine. L. felina had posterior and anterior cuspules on the lower canine. In one $L$. annectens and in L. canadensis the lower canine was hook-like.

TABLE 2 Number of mammae and vertebrae and dental formulae of otters. Sample size is given in parentheses.

\begin{tabular}{|c|c|c|c|c|c|c|c|}
\hline & \multicolumn{7}{|c|}{ Vertebrae } \\
\hline & Mammae & Cervical & Thoracic & Lumbar & Sacral & Caudal & Formula \\
\hline Lutra canadensis & $4(22)$ & $7(29)$ & $14(29)$ & $6(29)$ & $3(29)$ & $22(2)$ & $\frac{3}{3} \cdot \frac{1}{1} \cdot \frac{4}{3} \cdot \frac{1}{2}$ \\
\hline L. annectens & $4(2)$ & $7(15)$ & $15(15)$ & $5(15)$ & $3(15)$ & $\begin{array}{l}21(1) \\
25(1)\end{array}$ & $\frac{3}{3} \cdot \frac{1}{1} \cdot \frac{4}{3} \cdot \frac{1}{2}$ \\
\hline L. enudris & $4(2)$ & $7(2)$ & $15(2)$ & $5(2)$ & $3(2)$ & $\begin{array}{l}23(1) \\
24(2)\end{array}$ & $\frac{3}{3} \quad \frac{1}{1} \cdot \frac{4}{3} \cdot \frac{1}{2}$ \\
\hline L. platensis & $4(1)$ & $7(2)$ & $\begin{array}{l}15(4) \\
14(1)\end{array}$ & $\begin{array}{l}5(4) \\
6(1)\end{array}$ & $3(4)$ & $\begin{array}{l}24(1) \\
22(1)\end{array}$ & $\frac{3}{3} \cdot \frac{1}{1} \cdot \frac{4}{3} \cdot \frac{1}{2}$ \\
\hline L. provocax & $4(1)$ & - & - & - & - & - & $\frac{3}{3} \cdot \frac{1}{1} \cdot \frac{4}{3} \cdot \frac{1}{2}$ \\
\hline L. felina & $4(1)$ & - & $15^{*}$ & - & - & - & $\frac{3}{3} \cdot \frac{1}{1} \cdot \frac{3}{3}(4)$ \\
\hline L. lutra & $4(1)$ & $7(2)$ & $14(2)$ & $6(2)$ & $3(2)$ & $\begin{array}{l}23(1) \\
26(1)\end{array}$ & $\frac{3}{3} \cdot \frac{1}{1} \cdot \frac{4}{3} \cdot \frac{1}{2}$ \\
\hline L. sumatrana & $4(2)$ & - & - & - & - & - & $\frac{3}{3} \cdot \frac{1}{1} \cdot \frac{4}{3} \cdot \frac{1}{2}$ \\
\hline L. perspicillata & $6(1)$ & $7(1)$ & $14(1)$ & $6(1)$ & $3(1)$ & $23(1)$ & $\frac{3}{3} \cdot \frac{1}{1} \cdot \frac{4}{3} \cdot \frac{1}{2}$ \\
\hline L. maculicollis & $4(1)$ & $7(1)$ & $15(1)$ & $5(1)$ & $2(1)$ & $24(1)$ & $\frac{3}{3} \cdot \frac{1}{1} \cdot \frac{4}{3} \cdot \frac{1}{2}$ \\
\hline Amblony x cinerea & $4(1)$ & $7(5)$ & $14(5)$ & $6(5)$ & $3(5)$ & $\begin{array}{l}22(2) \\
20(2)\end{array}$ & $\frac{3}{3} \cdot \frac{1}{1} \cdot \frac{3}{3} \cdot \frac{1}{2}$ \\
\hline Aonyx capensis & $4(1)$ & $7(1)$ & $15(1)$ & $5(1)$ & $3(1)$ & - & $\frac{3}{3} \cdot \frac{1}{1} \cdot \frac{4}{3} \cdot \frac{1}{2}$ \\
\hline $\begin{array}{l}\text { Pteronura } \\
\text { brasiliensis }\end{array}$ & $4(1)$ & $7(1)$ & $\begin{array}{l}15(1) \\
14(1)\end{array}$ & $\begin{array}{l}5(1) \\
6(1)\end{array}$ & $3(1)$ & $19(1)$ & $\frac{3}{3} \cdot \frac{1}{1} \cdot \frac{4}{3} \cdot \frac{1}{2}$ \\
\hline Enhydra lutris & $2(1)$ & $7(2)$ & $14(2)$ & $6(2)$ & $4(1)$ & $19(1)$ & $\frac{3}{2} \cdot \frac{1}{1} \cdot \frac{3}{3} \cdot \frac{1}{2}$ \\
\hline
\end{tabular}

* from Pohle 1920 


\section{VERTEBRAL COUNTS}

Vertebral counts were made on a number of skeletons representing most species under study, as well as other species for comparative purposes. Results are summarized in Table 2. The counts of the caudal vertebrae are least accurate as it was difficult, in many cases, to be certain whether all vertebrae were present, since the terminal vertebrae are very small and easily lost or overlooked.

All specimens in the $L$. canadensis sample had, without exception, 14 rib-bearing vertebrae and differed in this respect clearly from all Neotropical forms (with the exception of one L. platensis), which not only have a greater number of ribs, but also seem to be more variable. No specimens of $L$. felina could be examined during this study, but it is reputed to have 15 thoracic and 5 lumbar vertebrae (Pohle, 1920) as do the majority of Neotropical forms. The vertebral formula of $L$. provocax is unknown, and unfortunately no skeletons were available for study. Most other Lutrinae examined show similar vertebral counts. The most aberrant is Enhydra with four sacral vertebrae (Barabasch-Nikiforov, 1962, lists three sacral vertebrae, however) and a reduction in the number of caudal vertebrae to 19 (18-21 according to Pohle, 1920). A similar reduction may be prevalent in Pteronura. It is of interest to note that these genera are more highly adapted to an aquatic existence than any of the Recent Lutrinae. In the more specialized pinnipeds, which like the Lutrinae employ the limbs in conjunction with body movements in locomotion, the tail is reduced even further to a very short appendage.

\section{BACULUM}

Bacula were, until recently, collected only rarely with the traditional skull and skin. The resulting dearth of bacula in most collections made it impossible to carry out comparisons between all forms under consideration. Relatively large numbers of bacula from L. canadensis were examined, but only two bacula from $L$. annectens and one from $L$. platensis were examined. The baculum of $L$. canadensis was described and illustrated in detail by Friley (1949), but the bacula of the Neotropical forms have never been described.

The baculum of a fully adult L. annectens ( $74.8 \mathrm{~mm}$ long) compared to a specimen from L. canadensis ( $94.9 \mathrm{~mm}$ long) of similar age, is noticeably smaller (Fig. $21 \mathrm{H}-\mathrm{K}$ ). Friley (1949) gives a mean of $94.92 \mathrm{~mm}$ and a range of 106.4-87.7 for adult Michigan specimens. The L. annectens baculum, therefore, lies well outside the range of $L$. canadensis. The juvenile bacula of the two forms, belonging to specimens in the same age group, revealed similar size difference.

Other differences between the two forms were found in the urethral groove. In $L$. annectens the flanges bordering the groove were spread out more, giving the groove a more gaping appearance in contrast to the narrower urethral groove of $L$. canadensis with its more parallel outline (Fig. $21 \mathrm{H}-\mathrm{K}$ ). In other respects the baculum of $L$. annectens was similar to that of $L$. canadensis. The immature baculum of $L$. platensis that was examined was short and relatively slender. The shaft was composed of 


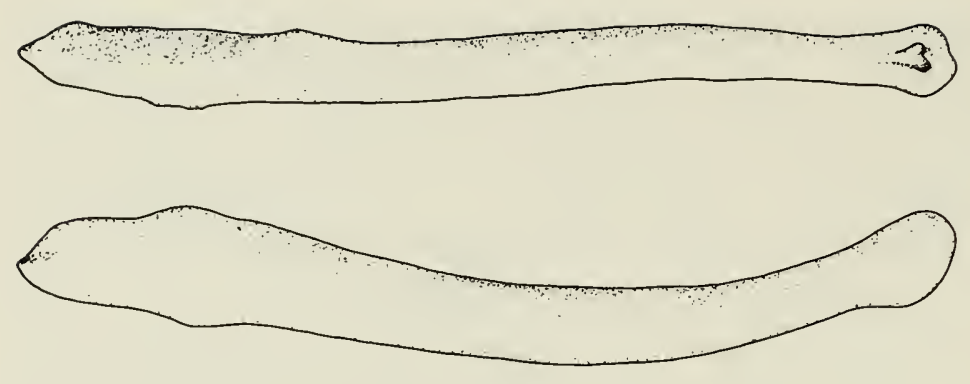

A

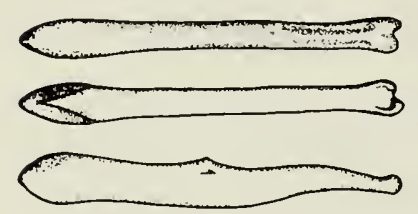

C
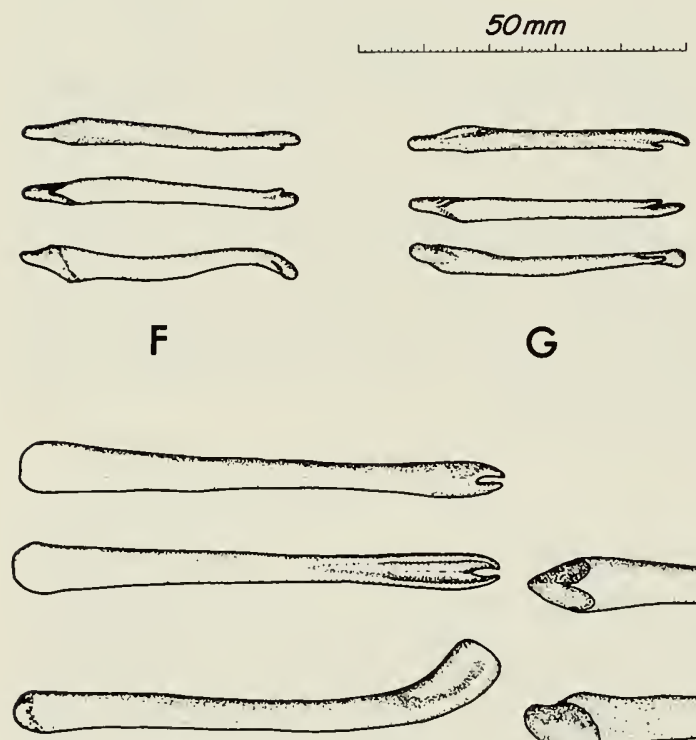

I
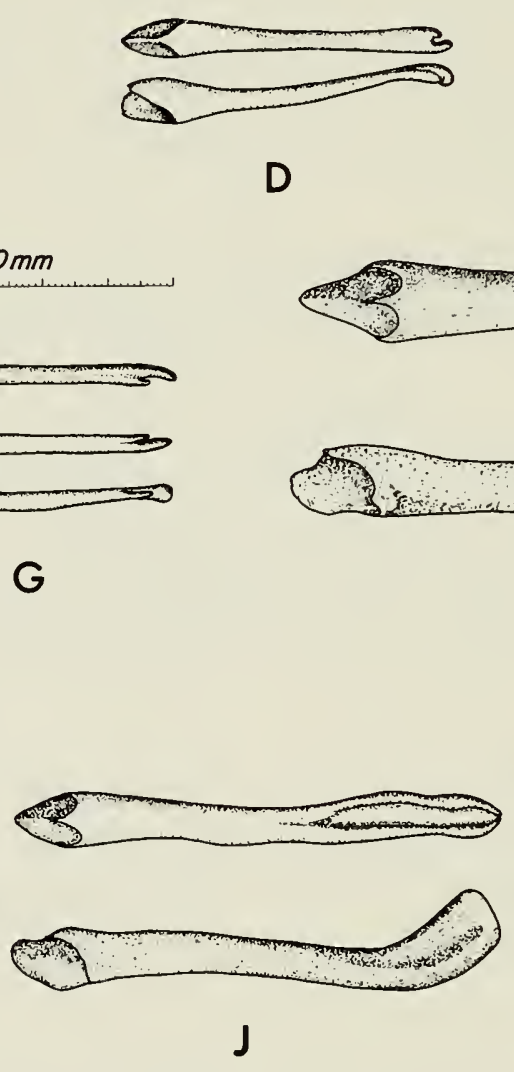

D

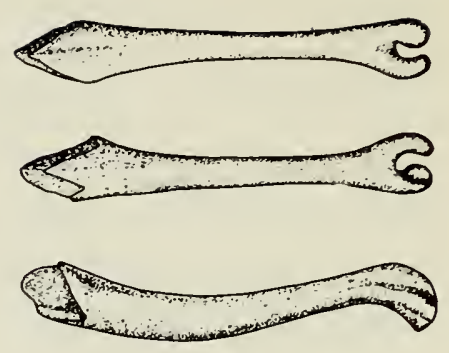

B

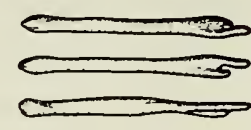

E

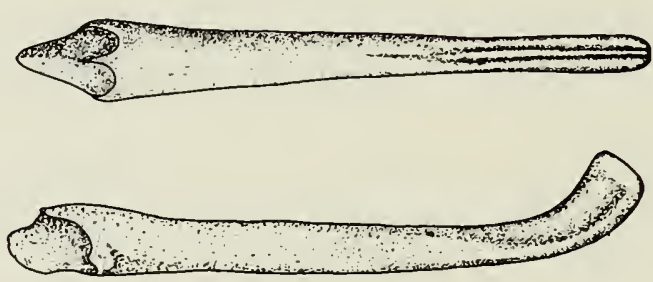

H

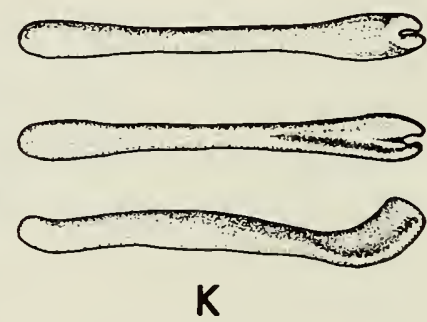

Fig. 21. Bacula. A. Enhydra lutris, adult, ventral and lateral views. B. Lutra lutra, adult, dorsal, ventral and lateral views. C. Pteronura brasiliensis, adult, dorsal, ventral and lateral views. D. Lutrogale perspicillata, adult, dorsal and lateral views (after van Bree, 1968). E. L. perspicillata, probably immature, dorsal, ventral and lateral views. F.-G. Amblonyx cinerea, adults, from Java and Assam respectively showing variation encountered within one species; dorsal, ventral and lateral views. H. L. canadensis, adult, ventral and lateral views. I. L. canadensis, immature, dorsal, ventral and lateral views. J. L. annectens, adult, ventral and lateral views. K. L. annectens, immature, dorsal, ventral and lateral views.

porous bone. The anterior end which had ossified to a greater extent possessed a urethral groove similar to the one described for L. annectens.

The bacula of the American forms were quite different from the baculum of L. lutra (Fig. 21 B) with which I compared it and which has been described as follows: "Posterior section of os penis thickened, but tapered toward base like a keel and markedly bent upward. Tip of bone bifurcated 
and pointing downward. Left lobe one and a half times as thick as right and bears a distinct longitudinal incisure below. Length of the baculum 58$65 \mathrm{~cm}$ (Ognev, 1931)." (Novikov, 1962.)

The rather striking difference between the bacula of these allegedly closely related New World and Old World forms invited further study of the baculum in other Lutrinae in the belief that it might provide important indications of the phylogenetic relationships within the Lutrinae. The skull, as an essentially trophic structure, is probably more directly subject to morphological change as a result of ecologically adaptive natural selection than the baculum, an internal structure unlikely to be influenced directly by the same selective forces (see also Mayr, 1963, p. 104). If this hypothesis were correct, as seems likely, it would suggest the possibility of close convergence in the ecologically similar species of the subfamily with respect to cranial, dental and external characters.

An attempt was therefore made to locate and examine bacula of all Recent species of otters. Unfortunately the bacula of many forms are not represented in collections at the present time and they are not easily obtained otherwise. However, in addition to the bacula already mentioned, the bacula of Lutrogale perspicillata ( = L. macrodus BM 15.11.1.80), Pteronura brasiliensis (AMNH 77735), Amblonyx cinerea (Bм 9.1.5.658, Bм 13.8.22.31, and BM 21.7.8.32) and Enhydra lutris (АMNH 90366) were examined. Published information on otter bacula was used as well.

There is no need to describe the bacula of all forms listed here. Brief descriptions and/or illustrations are available for the bacula of Lutrogale (van Bree, 1968) and Enhydra (Burt, 1960; Barabasch-Nikiforov, 1962). The baculum of Amblonyx was compared to that of L. lutra by Pocock (1921). The baculum of Pteronura has not been described before to my knowledge and a brief description of it is given here.

The baculum of Pteronura (Fig. $21 \mathrm{C}$ ) that was examined belonged to an adult and was characterized by small size. The distal end was weakly divided into two condyloid protuberances and it was somewhat flattened dorso-ventrally with a relatively broad and shallow ventral depression. The shaft or body was flattened somewhat laterally being higher than wide and it had a dorsal keel-like elevation half-way down its length. The proximal end was a little deeper and wider than the rest of the baculum and its surface was only slightly roughened.

In comparing the bacula of the different species, it became immediately evident that they differed most from each other in their distal ends. The body of the baculum was somewhat similar in most species, showing in cross section a rather straight ventral surface, more or less rounded sides with, in most cases, a somewhat apiculate or rounded dorsal surface. Usually the body was as deep as wide in its middle region, but in some forms (e.g., L. lutra and P. brasiliensis) it was slightly flattened laterally. The lateral outline of the body may be straight or slightly S-shaped, but this seems to be variable within species. The shape of the proximal end, which is usually well defined in adults by a marked line of demarcation and a roughened surface, is rather variable within species and provides few useful characters to separate the different forms. 


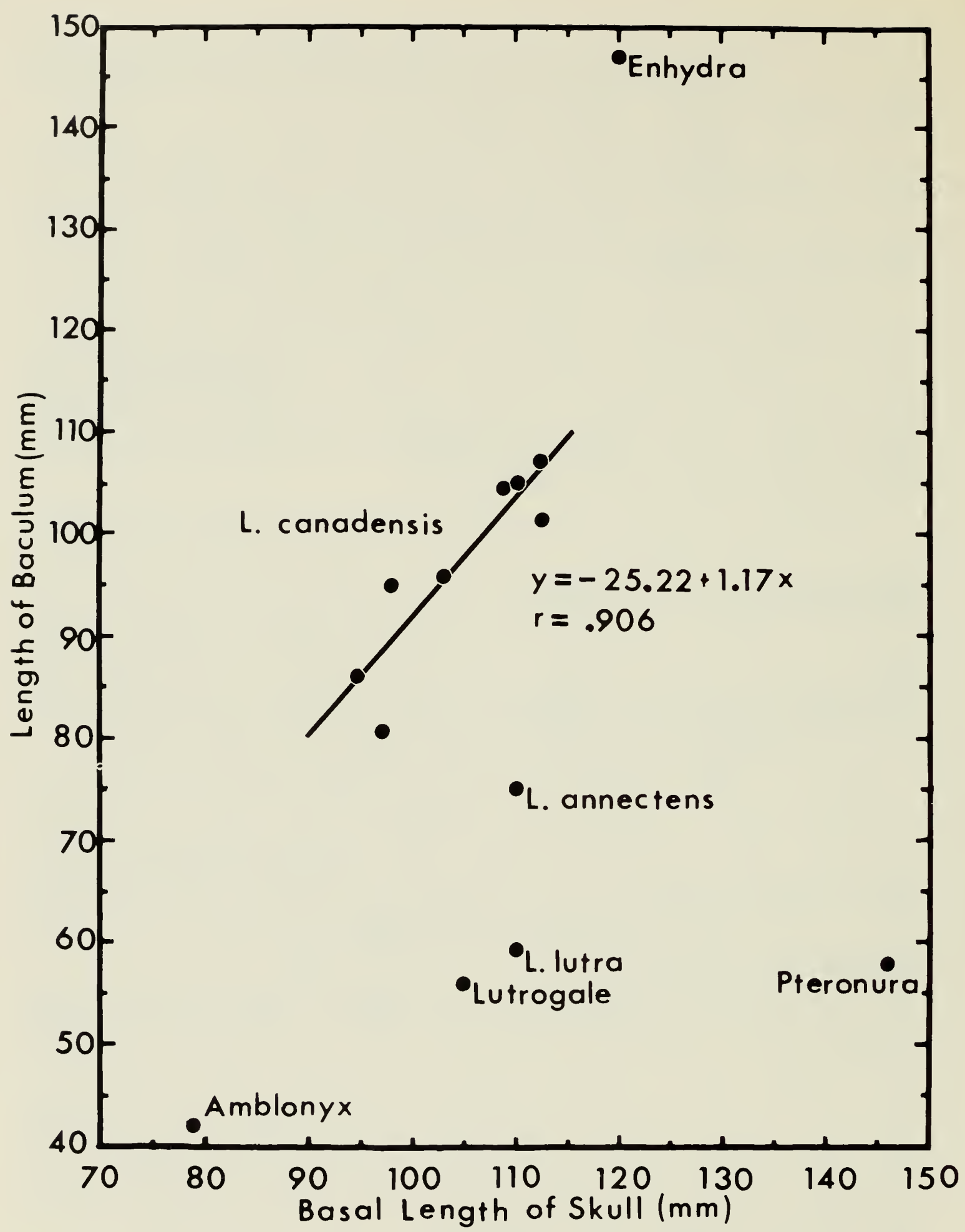

Fig. 22. Length of the baculum relative to basal length of the skull in adult otters. The L. canadensis cluster contains specimens of the largest and smallest subspecies. The formula is for Bartlett's line of best fit.

The tip of the baculum is, therefore, the most specialized part and all otters examined can be distinguished from one another by the tip alone. Bifurcation of the tip appears to be a basic characteristic of most otter bacula, although this feature has been modified in some forms and is barely recognizable in others.

The Eurasian river otter L. lutra shows the clearest example of bifurcation (see Fig. 21 B). Amblonyx and Lutrogale also show bifurcation, but the asymmetry noted in L. lutra is in these forms much more pronounced. 
The left branch is more developed than the right in Amblonyx, as it is in L. lutra, but the difference is much greater (Fig. $21 \mathrm{~F}, \mathrm{G}$ ). In Lutrogale the situation is similar but reversed, the right branch being much larger than the left (Fig. $21 \mathrm{D}, \mathrm{E}$ ).

Other differences between L. lutra and Amblonyx and Lutrogale are that the tip in the latter two is straight or only very weakly curved downward and the terminal branches are rounder and not laterally flattened. The body and anterior end are also of relatively even width in contrast to the condition in L. lutra.

In the other forms examined the bifurcation is much less pronounced or has been modified. In Pteronura the baculum is weakly bifurcated, as noted before, and the tip which is wider than deep is also not curved in this genus. In the American river otters examined, the bifurcation is only evident in the immature baculum (Fig. $21 \mathrm{I}, \mathrm{K}$ ) when the antero-dorsal part of the anterior end has not yet ossified. The bacular tip of the American river otters curves dorsad in contrast to that of all other forms which were examined and is laterally flattened. The adult baculum of $E_{n-}$ hydra shows no bifurcation (Fig. $21 \mathrm{~A}$ ).

All forms show a more or less clearly marked depression on the anterior ventral side of the baculum. In the American forms examined, the depression is very well developed and forms a clearly defined urethral groove quite distinct from that of any of the other forms.

Apart from the morphological differences, there exists considerable variation in the relative size of the adult baculum of the different forms. If the length of the baculum is plotted against the corresponding basal length of the skull, used as an index of overall size, Enhydra is seen to have the largest and Pteronura the smallest baculum relative to size (Fig. 22). The remaining species lie somewhere in between, but the American forms $L$. canadensis and $L$. annectens have distinctly larger bacula than the Old World forms L. lutra, Lutrogale and Amblonyx which have bacula of similar relative size.

In a small sample of adult $L$. canadensis $(n=8)$ the trend line was approximately isometric and there was a high correlation between the two variates $(r=0.906)$. The position of the adult baculum of $L$. annectens was quite distinct from the L. canadensis distribution suggesting specific separation of the two forms.

Morphological comparison of the baculum of the forms mentioned shows firstly the distinctness of the American forms from all others and secondly a clear difference between the Nearctic and Neotropical forms, L. canadensis and L. annectens.

\section{RHINARIUM}

The shape of the rhinarium has long served to distinguish the different American species of Lutra, and occasionally species determination has been based solely on this character. Whether such reliance on this character is warranted is questionable. The validity of this character was first doubted by Thomas (1920) after he found two different types of nose pad in otters from the same locality. A review of the geographic variation 
of the rhinarium therefore appeared pertinent. Unfortunately such a review is hampered by an insufficient number of specimens from South America, but it is hoped that published observations supplemented by observations made here will contribute to the understanding of the variability of this character. The basic shapes of the rhinarium found in the different otters are described in the synopses (p. 84-88), and are depicted in Fig. 23.

In $L$. canadensis and $L$. felina the shape of the rhinarium remains constant throughout their geographic range. The annectens-type occurs in otters throughout Mexico, Central America and the northwestern section of South America west of the Andes and south at least to Ecuador. It may also occur in extreme northwestern Peru. All specimens from these areas that were examined or reported in the literature conformed to the annectens-type. Hall and Kelson (1959) stated, however, that the rhinarium of $L$. annectens may be straight dorsally, which is taken from Pohle (1920, p. 96). This description may be erroneous as Allen's (1908) original description from which Pohle in turn derived his information says: "Nose pad rounded above, as in Central and South American forms of Lutra. . . ." The only aberrant nosepad described from this area is that of $L$. mesopetes by Cabrera $(1924$, p. 12$)$. The annectens-type of rhinarium is again encountered in $L$. provocax in Chile and Patagonia.

The greatest variability in the shape of the rhinarium exists in the remaining area east of the Andes occupied by L. enudris and L. platensis. In specimens from Guyana and Surinam, the rhinarium is divided by a median band of hair. The condition of the rhinarium of otters on Trinidad is said to be the same (Pohle, 1920). In a specimen from Kartabo in Guyana this strip of hair measured $2.9 \mathrm{~mm}$ at the narrowest point, in another specimen from Providence in the same country it was $4.9 \mathrm{~mm}$, and in a specimen from the Saramaca River in neighbouring Surinam the same measurement was only $0.8 \mathrm{~mm}$. Specimens from Venezuela were not available for examination; Pohle (1920) mentioned one from the Caura that had a bare rhinarium but added that the hair seemed to have been worn off. Two specimens from Guaicaramo, Colombia, showed a median hairy strip $2.9 \mathrm{~mm}$ wide at the narrowest point in one and in the other a dorsal, hairy, downward projection and a similar upward projection from below, which failed to meet. A rhinarium similar to the latter was observed in a specimen from the Río Pastaza in eastern Ecuador.

To the south in Peru a number of shapes occur. A female from the Río Comberciato had an annectens-type nosepad (the same specimen referred to by Thomas, 1920), although compared with most $L$. annectens its bare upward projection was not as pronounced and the upper boundary appeared to be weakly biconcave. Another specimen from Pachitea had a bare rhinarium, the dorsal outline curving downward but not forming an acute downward projection. Thomas (1908) described the rhinarium of $L$. incarum from Peru as "ill defined, the hairy part from above projecting downward in the middle without any very clear line of demarcation and in some cases almost or quite meeting a corresponding upward projection from below." It is not clear whether this description was based on 


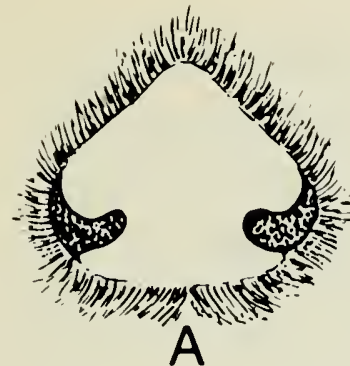

A

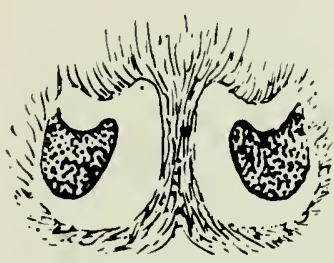

E
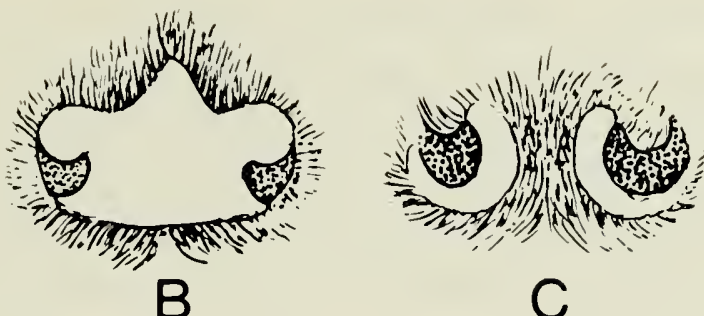

C

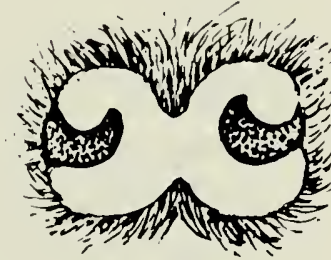

$\mathrm{F}$

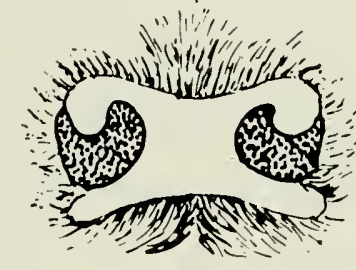

G

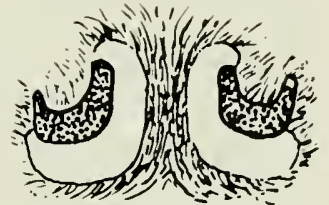

D

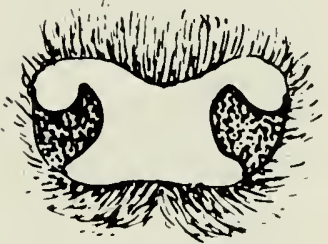

$\mathrm{H}$

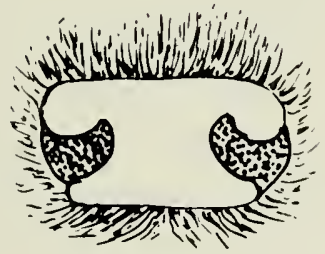

I

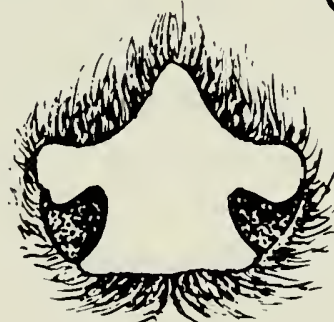

$J$

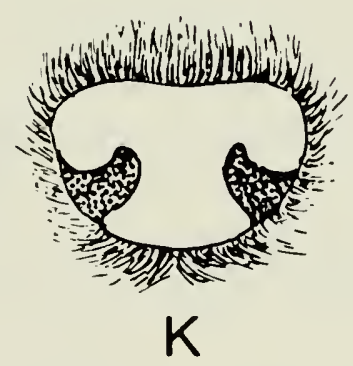

Fig. 23. Rhinaria of American river otters. A. L. canadensis. B. L. annectens. C, D. E, F and G. Variation in hairiness of the rhinarium of L. enludris, specimens figured here from the Amazon drainage basin. $\mathrm{H}$ and I. L. platensis. J. L. provocax. K. L. felina.

the skin of the type and/or on specimens from Eten on the northwest coast. But Thomas later (1920) referred to ". . . the two examples of $L$. incarum Thomas, . . . both show the form of the nosepad found in L. platensis." The original description of $L$. incarum, however, agrees with some of the nosepads of L. enudris, from eastern Ecuador and eastern Colombia, which are basically the same as those found on the north coast but without the continuous median band of hair. The rhinaria of both specimens examined here were unlike the typical nosepad of L. platensis which is straight in upper and lower outlines.

The rhinarium of a juvenile specimen from the Río Itenez in Bolivia was bare and lacked any indication of a median strip or upward and downward hairy projections. Pohle (1920, p. 216) considered the otters inhabiting the Río Guapore, of which the Río Itenez is a part, to be $L$. platensis, presumably on the basis of the shape of the nosepad, although these rivers are part of the Amazon system. The shape of the rhinarium in otters from the eastern coast of Brazil was not determined. However, a specimen from the Río Tocantins in eastern Brazil had a bare rhinarium with a dorsal hairy downward projection and a corresponding upward projection from below which did not meet. All specimens of L. platensis from the Paraná River system that were examined had nosepads conforming to the illustrations in Fig. $23 \mathrm{H}$ and $\mathrm{I}$.

The above observations on the geographic variation of the shape of the rhinarium east of the Andes mountains, give sufficient information to arrive at a number of tentative conclusions. The first is that the enudris- 
type rhinarium and the platensis-type rhinarium are linked by intermediate types. Secondly, the change may be clinal from north to south, or there may be a broad zone of intergradation between the types. Locally, as in Peru, the observed variation may indicate a steeper zone of intergradation of the two types. Thirdly, it is concluded that the rhinarium has limited value as a diagnostic character in South American otters.

\section{PLANTAR PADS}

Major differences in the soles of the feet are the degree of hairiness and the degree of roughness of the bare skin covering the pads. L. canadensis is distinguished from the majority of Neotropical forms by various amounts of hair between the pads and a rough granular skin covering the pads. Only in L. provocax and L. felina are the pads as rough. Apparently hairiness and roughness form an antislip mechanism and are correlated with the occurrence of icy conditions.

MAMMAE

All American Lutra and most other species that were examined had four abdominal mammae (see Table 2).

\section{PELAGE}

Differences in pelage, observed in the length of the hairs and in colouration, were not striking when the Nearctic and Neotropical groups were compared.

The difference in the length of the hairs and their density is clearly related to climate. In the northern $L$. canadensis and the southern $L$. provocax and L. felina, the coats are long and dense; tropical forms such as enudris and annectens are often short-haired. In L. felina the guard hairs are coarse and more erect. In all other forms the guard hairs are smooth and shiny and lie near to the body.

The colour in all forms is basically uniform brown but varying from nearly black to lighter shades of brown; all otters are darker dorsally and somewhat lighter ventrally. The lightest and most variable pelage is found at the throat and lower jaw and varies from whitish or yellowish to light brown. Wool hair is lighter than guard hair, varying from dirty white to gray or dull brown to orange-brown. Pelts of $L$. annectens from west of the Andes mountains and of $L$. enudris from east of the Andes mountains could always be distinguished by the orangeish underfur of the latter. Within $L$. canadensis the eastern $L$. c. canadensis and $L$. c. degener are the darkest, the southern and western forms are lighter and generally have a greater degree of saturation. These findings agree with observations made in the fur trade for Canadian pelts. According to Ruttle (1968), extra dark pelts are produced in Ontario and other eastern provinces, whereas western pelts, which can be further divided into the large pelts from the British Columbia coast and the smaller inland pelts, are generally lighter.

The reflectance curves plotted from the reflectance readings at 10 different wavelengths presented the same basic pattern for all forms for 
dorsal and ventral areas (Table 3 ). Reflection increased with increasing wavelength and produced a curve similar to that described for melanin pigmented birds by Dyck (1966). The dominant wavelength, although showing considerable variation in the total sample, has approximately similar values, $570 \mathrm{~nm}-606 \mathrm{~nm}$ for Nearctic and Neotropical forms. Dyck (1966) reported a narrower range $(579-585 \mathrm{~nm})$ for melanin pigmented plumage areas in birds. Saturation and brightness tend to be greater in most Neotropical forms; saturation and brightness for the dorsal area ranged from $2-6 \%$ and $10-14 \%$ in $L$. canadensis and from $4-10 \%$ and $12-15 \%$ in Neotropical species. Ventrally saturation ranged from 5-16\% and brightness from $13-21 \%$ in canadensis and from $14-21 \%$ and $17-27 \%$ in the Neotropical forms.

$L$. a. repanda, $L$. a. parilina, $L$. platensis and $L$. felina are the darkest Neotropical taxa, and are similar to many subspecies of $L$. canadensis. But contrast of dorsal and ventral colouration is more pronounced in the Neotropical forms. The ventral surface averaged approximately $11 \%$ (7-14) lighter in Neotropical forms as opposed to only about 5\% (2-9) in the Nearctic forms. L. platensis and L. felina showed the least contrast of the Neotropical forms: 7 and 5\% respectively. A similar increase in saturation between dorsal and ventral surface occurs.

In general, colouration is not a discontinuous character separating the Nearctic from the Neotropical otters; although there are noticeable and demonstrable differences, the overlap is such that some taxa cannot be distinguished by colour alone.

TABLE 3 Reflectance values for skins of American river otters by original taxa. Sample size is given in parentheses.

\begin{tabular}{|c|c|c|c|c|c|c|}
\hline & \multicolumn{3}{|c|}{ DORSAL } & \multicolumn{3}{|c|}{ VENTRAL } \\
\hline & $\begin{array}{l}\text { Hue } \\
(\mathrm{nm})\end{array}$ & $\begin{array}{l}\text { Satu- } \\
\text { ration } \\
(\%)\end{array}$ & $\begin{array}{c}\text { Bright- } \\
\text { ness } \\
(\%)\end{array}$ & $\begin{array}{l}\text { Hue } \\
(\mathrm{nm})\end{array}$ & $\begin{array}{c}\text { Satu- } \\
\text { ration } \\
(\%)\end{array}$ & $\begin{array}{c}\text { Bright- } \\
\text { ness } \\
(\% / 0)\end{array}$ \\
\hline Lutra c. canadensis (Ont.) (7) & 572 & 2 & 10 & 584 & 10 & 15 \\
\hline L. c. degener (4) & 570 & 2 & 10 & 571 & 6 & 13 \\
\hline L. c. evexa (juv.) (1) & 570 & 2 & 11 & 574 & 11 & 16 \\
\hline L. c. lataxina (1) & 580 & 4 & 11 & 606 & 5 & 15 \\
\hline L. c. vaga (11) & 574 & 1 & 11 & 577 & 8 & 14 \\
\hline L. c. preblei (3) & 574 & 6 & 12 & 580 & 9 & 21 \\
\hline L. c. yukonensis (1) & 585 & 4 & 12 & 591 & 16 & 18 \\
\hline L. c. optiva (2) & 578 & 6 & 13 & 583 & 14 & 20 \\
\hline L. c. pacifica (2) & 573 & 2 & 11 & 585 & 10 & 16 \\
\hline L. c. vancouverensis (4) & 585 & 2 & 11 & 580 & 7 & 14 \\
\hline L. c. periclyzomae (9) & 582 & 4 & 14 & 582 & 10 & 16 \\
\hline L. a. annectens (2) & 584 & 10 & 13 & 577 & 21 & 24 \\
\hline L. a. latidens (2) & 586 & 9 & 15 & 580 & 16 & 26 \\
\hline L. a. repanda (1) & 590 & 8 & 12 & 576 & 18 & 26 \\
\hline L. a. parilina (4) & 585 & 5 & 13 & 580 & 18 & 24 \\
\hline L. enudris (4) & 584 & 8 & 14 & 585 & 18 & 25 \\
\hline L. platensis (4) & 584 & 4 & 12 & 582 & 14 & 19 \\
\hline L. provocax (2) & 590 & 9 & 13 & 585 & 18 & 27 \\
\hline L. felina $(5)$ & 577 & 6 & 12 & 581 & 16 & 17 \\
\hline
\end{tabular}




\section{Overall Similarity}

The results of cluster analysis of the half-matrix of distance coefficients between each sample are expressed in Fig. 34. Upper and lower dentitions as well as skulls of all forms included in this analysis are illustrated in Figs. 17-20 and 24-33 to allow comparisons with the degrees of similarity expressed in the phenogram.

The clusters obtained and the levels of association, expressing the similarity between them, are partially in agreement with current taxonomic views, but also show some rather important deviations. In analyzing the phenogram, an attempt is made to explain the observed similarity and to examine additional evidence not used in the analysis in order to assess the general validity of the arrangement and the probable relationships implied by it. In addition the distortion of the similarities expressed by the phenogram as compared to those in the similarity half-matrix are investigated.

Distinct clusters representing the Nearctic and Neotropical groups are easily recognized. All forms of $L$. canadensis are combined in one large cluster composed of a number of subsidiary clusters. The large Neotropical forms constitute a similar group with L. provocax joining at a distinctly lower level. The North American forms and the large Neotropical forms then join at an even lower level. L. felina is the last member of the American group to join the cluster and does so well below the level of association of the large forms of the group.

The Old World Lutra form a similar cluster. The three geographic samples of $L$. lutra, which are generally included within a single subspecies (lutra), join at a level similar to that of most subgroups of $L$. canadensis, but higher than its most divergent subspecies. Unfortunately the more divergent subspecies of L. lutra could not be included because of inadequate samples. L. sumatrana and L. maculicollis associate at a lower level, after which their cluster joins that of L. lutra at approximately the same level as the base of the cluster representing the American river otters.

Returning to the American cluster, we see that it is joined at succeeding lower levels with Amblonyx and Aonyx respectively. At a similar level (between 8.0 and 8.5) at the extreme left side of the phenogram the genera Pteronura and Lutrogale join before associating with the Old World Lutra cluster. The Pteronura, Lutrogale, Old World Lutra group then join the American Lutra-clawless otter group before they are finally joined to Enhydra.

The subsidiary clusters of $L$. canadensis correspond to geographically neighbouring populations. A notable exception is L. c. chimo which associates with $L$. $c$. evexa rather than with its geographical neighbours. According to the distance coefficients in the similarity half-matrix, the similarity of $L$. c. chimo and $L$. c. canadensis from Ontario and the MaritimesNew England areas is similar to that of $L$. c. chimo and $L$. c. brevipilosus and $L$. c. evexa $(9.640,9.657$ and $9.658,9.647$ respectively). On geographic grounds it is, therefore, preferable to associate $L$. c. chimo with the L. c. canadensis group. 
The most aberrant of the L. canadensis subgroups is the miravancollverensis group. It should be pointed out here that L. c. pacifica from the coast of British Columbia were included with $L$. c. vancouverensis because of similar measurements (Appendix 3) and geographic proximity. The combined sample appears under the name L. c. vancouverensis in the phenogram (Fig. 34).

In the large Neotropical forms we can see general agreement with the observations made in the allometric analysis, as was to be expected. $L$. enudris and $L$. platensis are closely associated. The subspecies of $L$. annectens are not entirely arranged as expected, but small sample size may have affected the results here. For example $L$. a. latidens was represented by a small sample containing one very large specimen and a number of medium sized specimens; thus the ratio of the means probably does not reflect the true condition in the population. Despite this, however, the annectensenudris-platensis group is comparable to L. canadensis which agrees with conclusions reached earlier in the discussion and summary of the allometric analysis. The same can be said about the position of $L$. provocax, which, as has been established previously, is the most differentiated of the large Neotropical forms. Also entirely in accordance with previous conclusions is the position of L. felina. It may be concluded that the similarity of the American forms, as expressed in the phenogram, is supported by all other evidence examined in this study and probably represents a good approximation of the degree of relationship between the forms.

The phenogram association of the American group of river otters with the clawless otters Aonyx and Amblonyx was not expected, as they are usually not associated with one another. However closer examination makes this association understandable. If we refer to an actual specimen we notice that there are a number of resemblances. In dental characters the American group is in many ways intermediate between the clawless otters and the more primitive toothed, Old-World Lutra. We may even postulate that the ancestors of the present day clawless otters, such as Aonyx and Amblonyx, may have passed through a structural stage somewhat similar to that of the Recent American forms. In the American river otters there is a tendency towards a broadening of the teeth, by an increase in the crushing components. This is most pronounced in L. provocax, and least in L. felina which may have developed secondary narrowing of its dentition during the course of its evolution. In contrast to most clawless otters, there has not been a corresponding reduction in the height of the cusps in the American group, which have become blunt and rounded in Aonyx. Amblonyx, however, has retained relatively high pointed cusps and shearing blades. Its teeth are, however, very broad, having large crushing surfaces. The dentition of Amblonyx, therefore, resembles that of American forms more than does that of Aonyx. The dentition of most American river otters may be regarded as a dual purpose dentition. adapted equally well for crushing and cutting.

The skulls of Aonyx and Amblonyx also bear a certain resemblance to those of the American river otters, as they are comparatively short and 

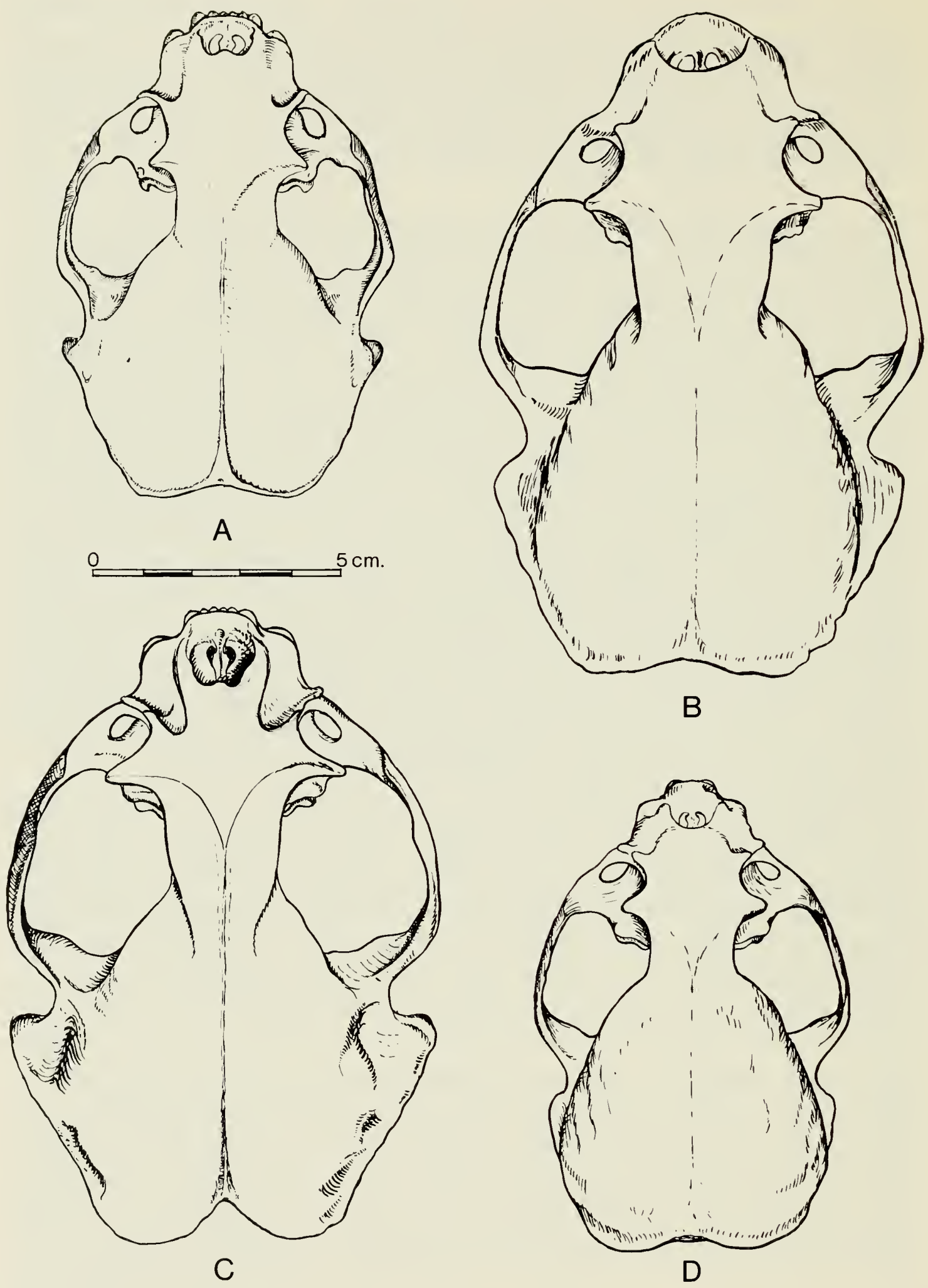

Fig. 24. Dorsal view of otter skulls. A. L. canadensis adult or from Ontario (ROM 16652). B. L. canadensis adult $\&$ from the British Columbia coast (PMBC 1865). C. $L$. annectens adult or (ROM 35057). D. L. annectens adult \& (CAS 9159). 

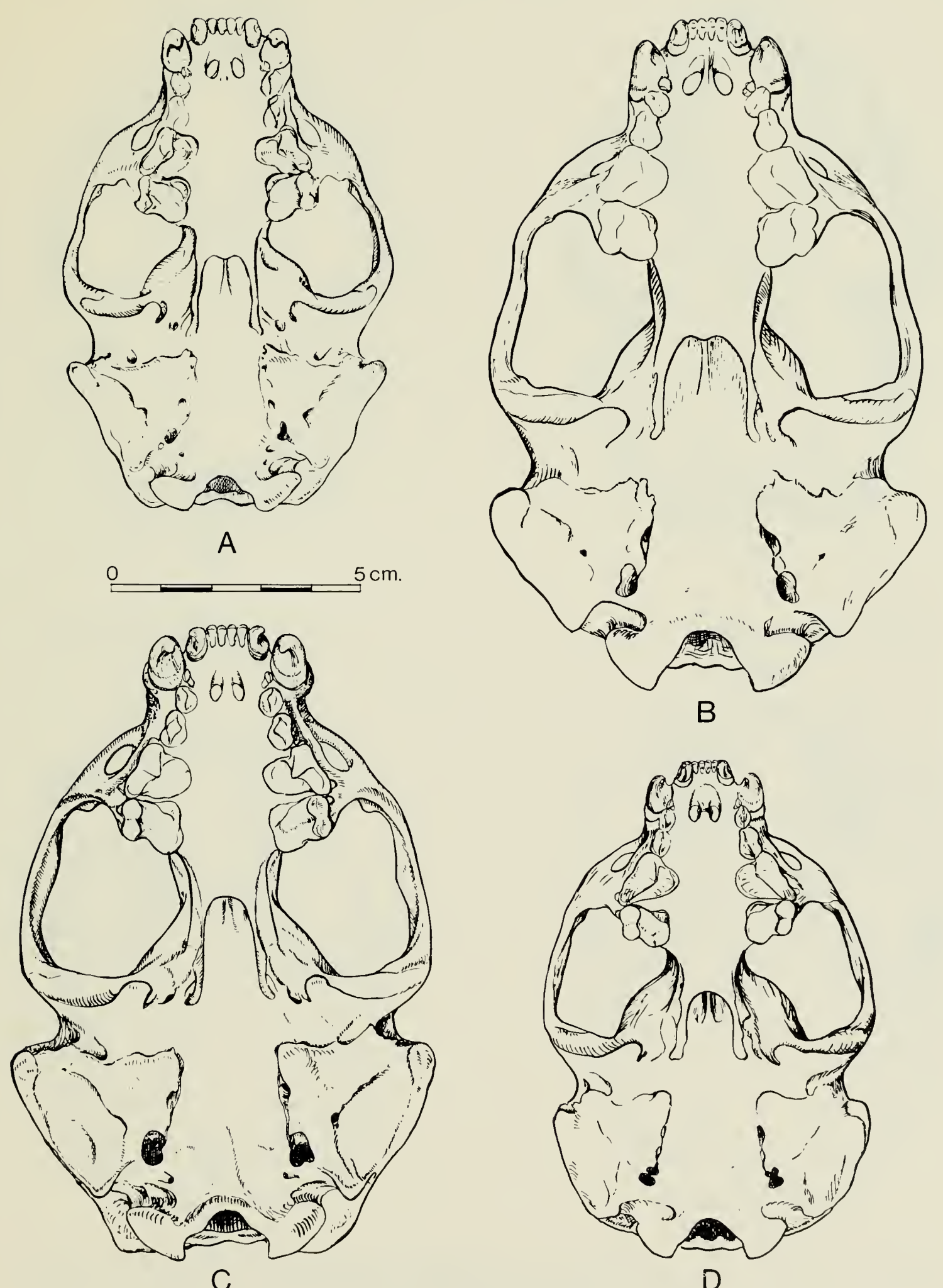

Fig. 25. Ventral view of otter skulls, details as in Fig. 24. A. L. canadensis or. B. $L$. canadensis o. C. L. annectens or. D. L. annectens of. 


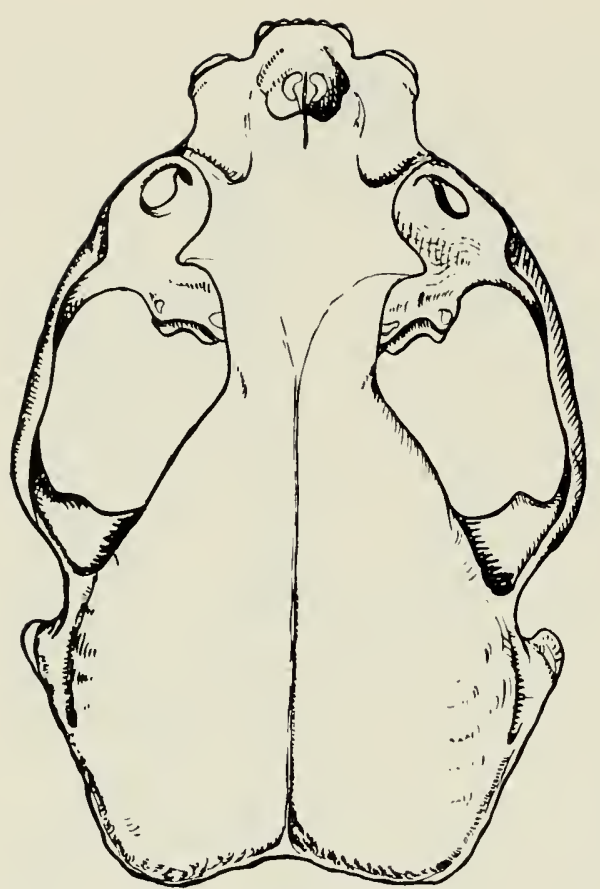

A

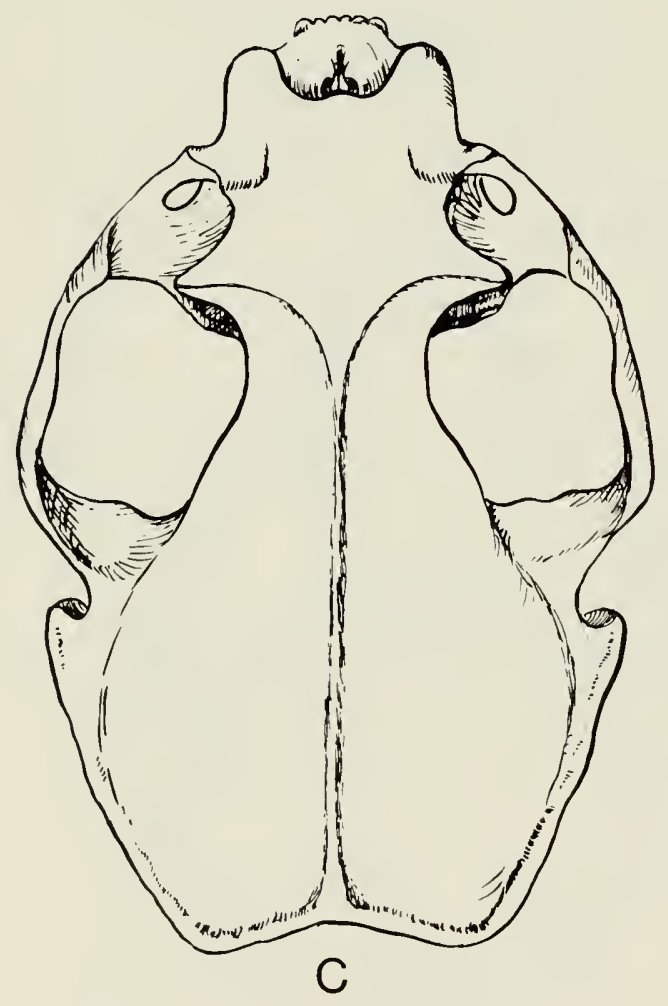

Fig. 26. Dorsal view of otter skulls. A. L. entudrs young adult or (BM 1937-7-18-1). B.

L. enudris young adult \& (ROM 32326). C. L. platensis adult or (after Pohle, 1920). D. L. platensis adult, probably o (ZM L15).
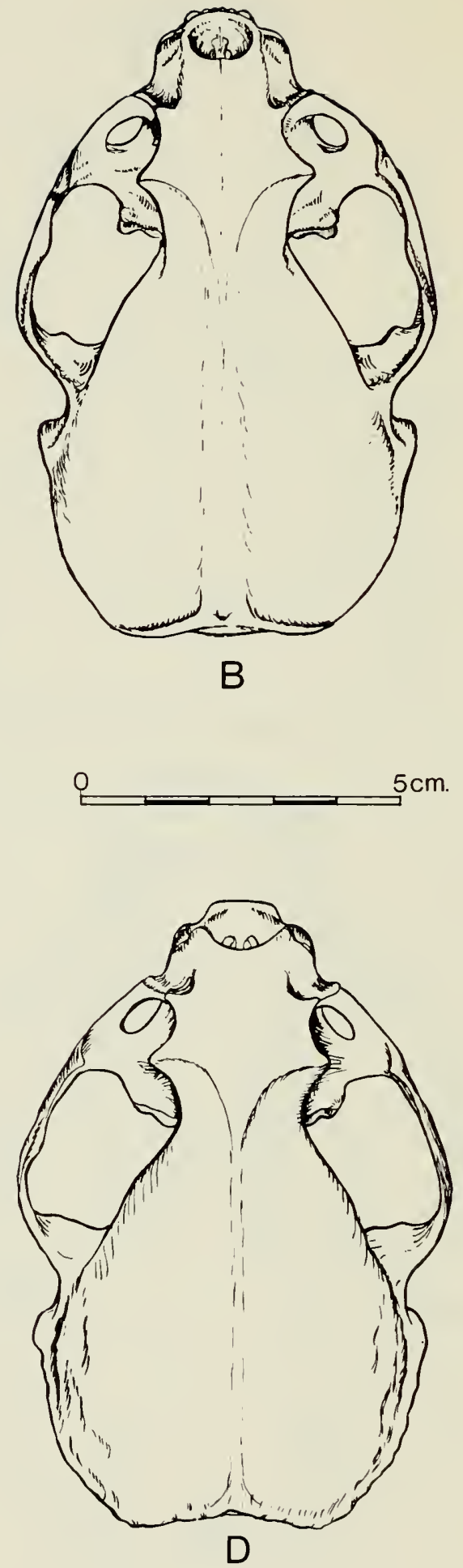
(1) 


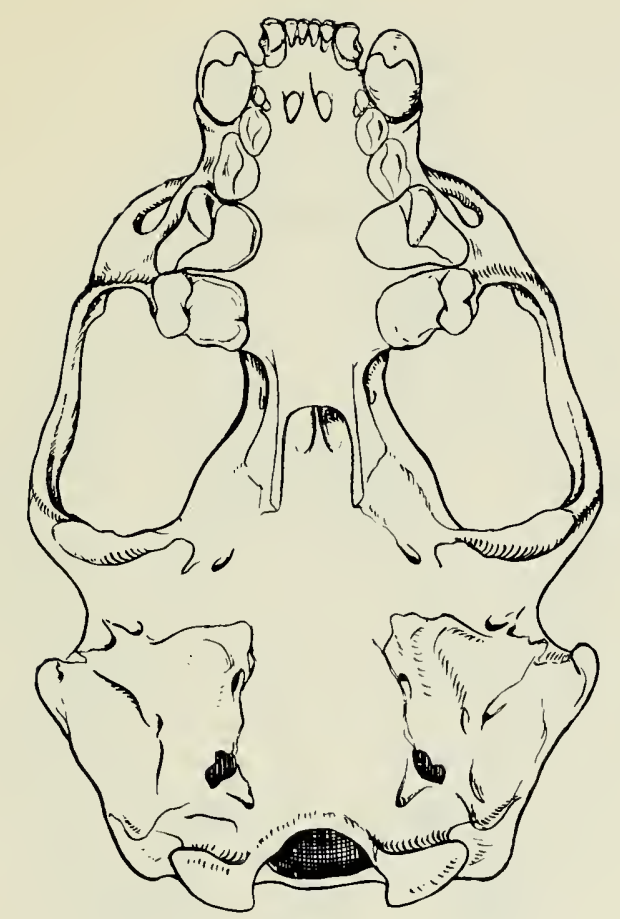

A

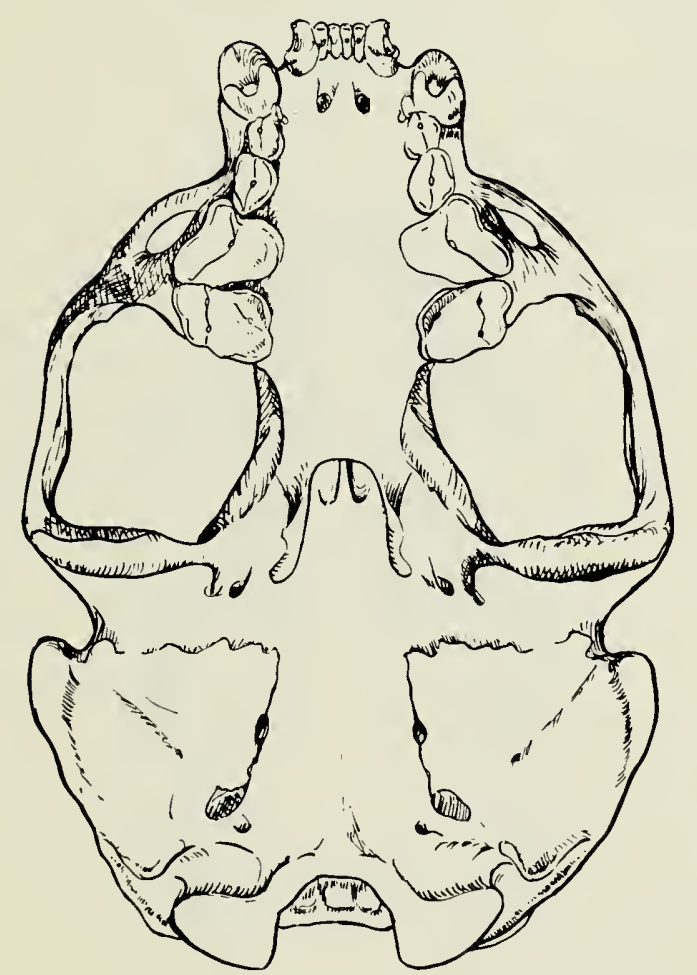

C

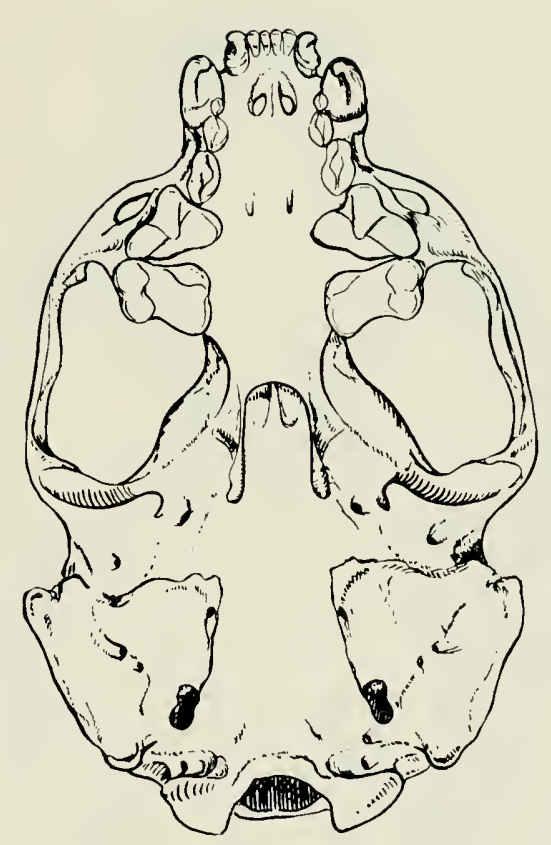

B

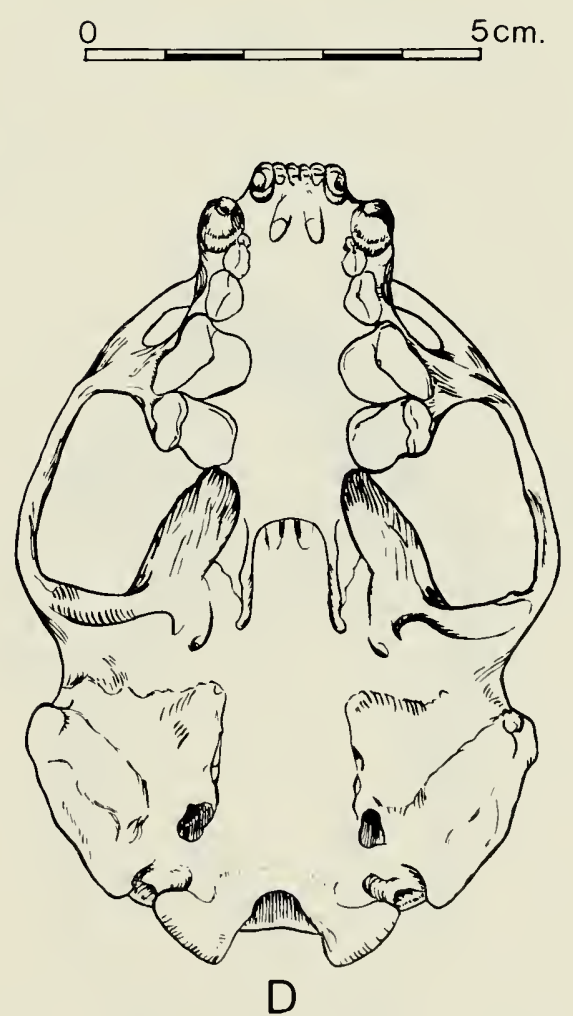

D

Fig. 27. Ventral view of otter skulls, details as in Fig. 26. A. L. enudris. B. L. enudris. C. L. platensis. D. L. platensis. 


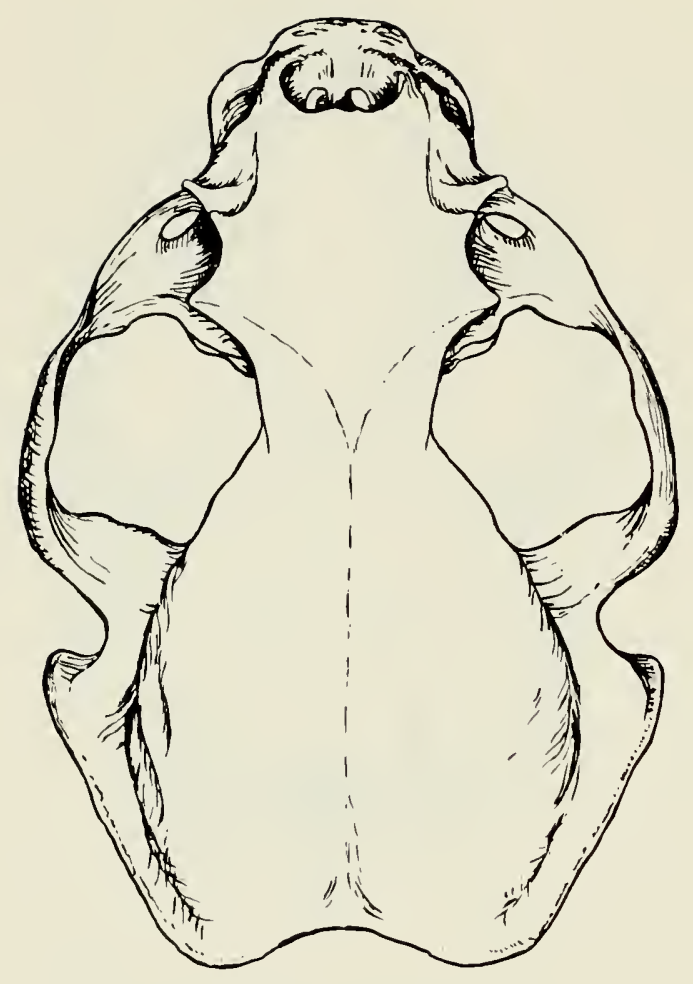

A

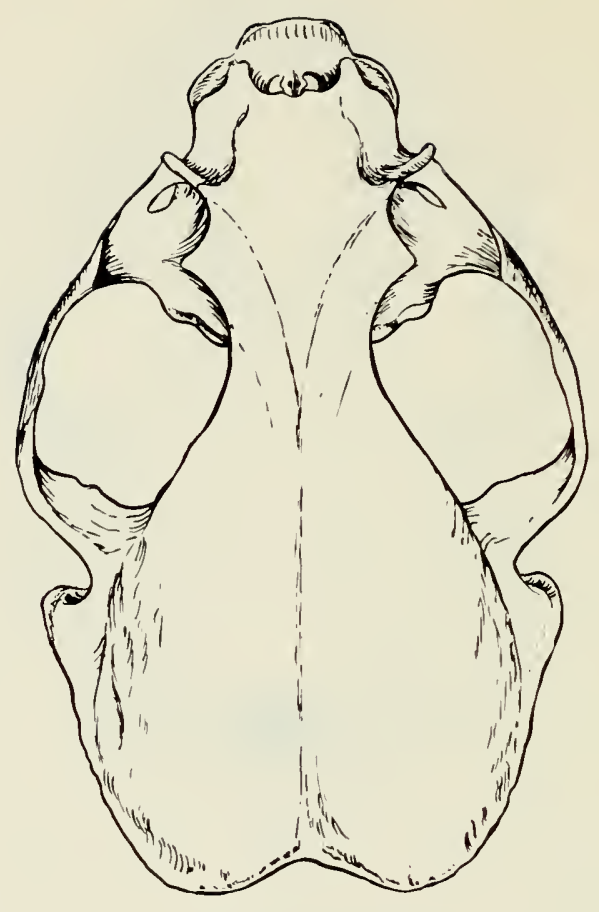

B
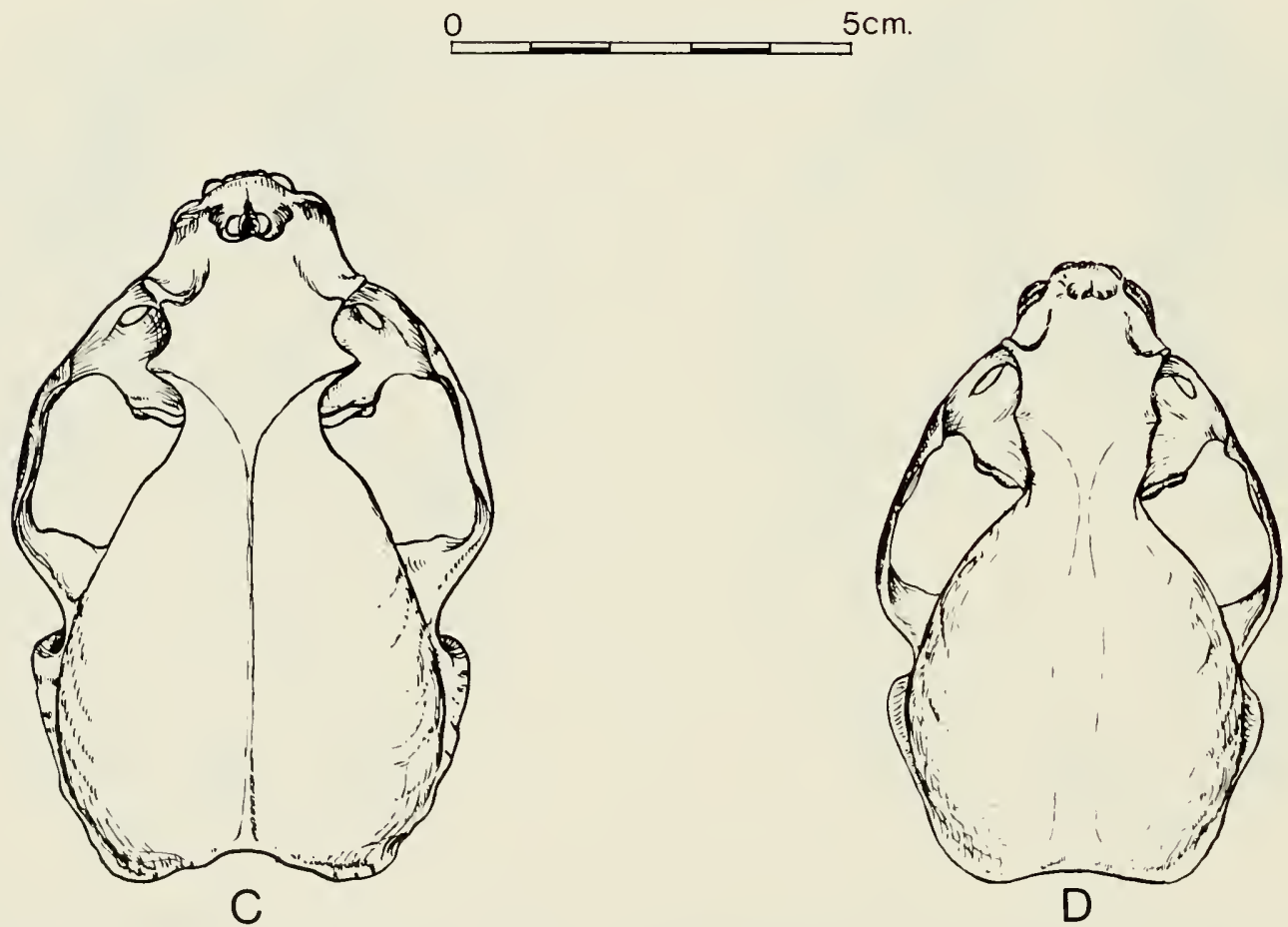

Fig. 28. Dorsal view of otter skulls. A. L. provocax sex unknown. but probably or (NMFIs 146). B. L. provocax adult or (FMNH 24224). C. L. felina adult or (FMNH 24223). D. Amblonyx cinerea adult, probably or (FMNH 88611). 


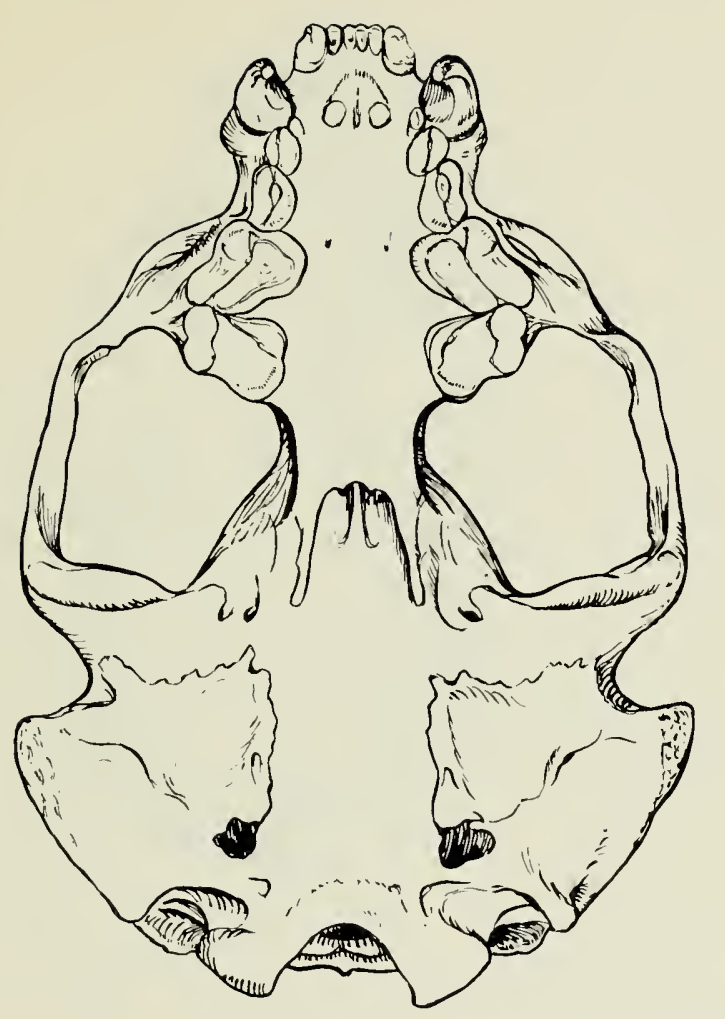

A

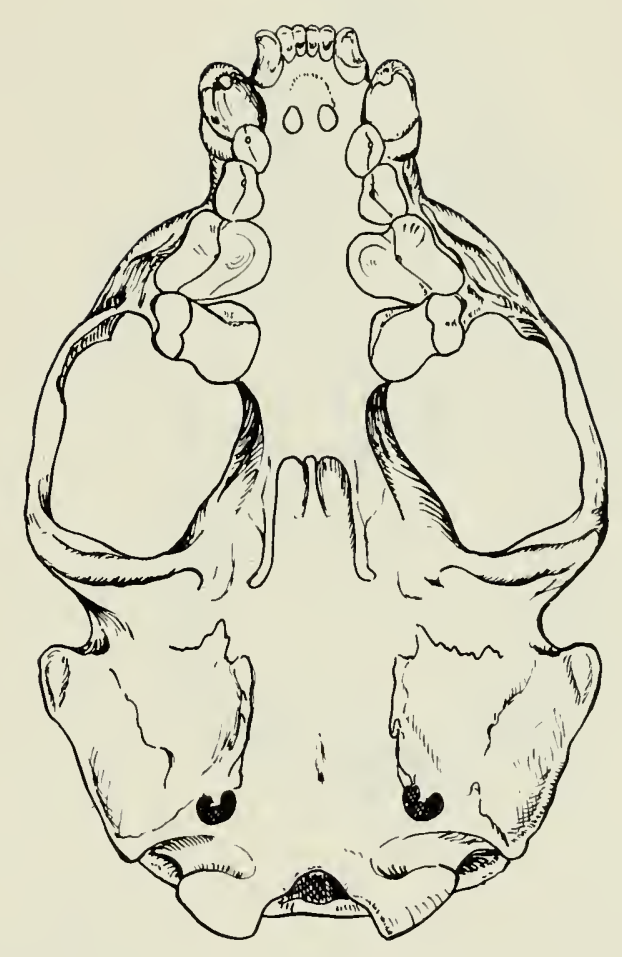

B $5 \mathrm{~cm}$.
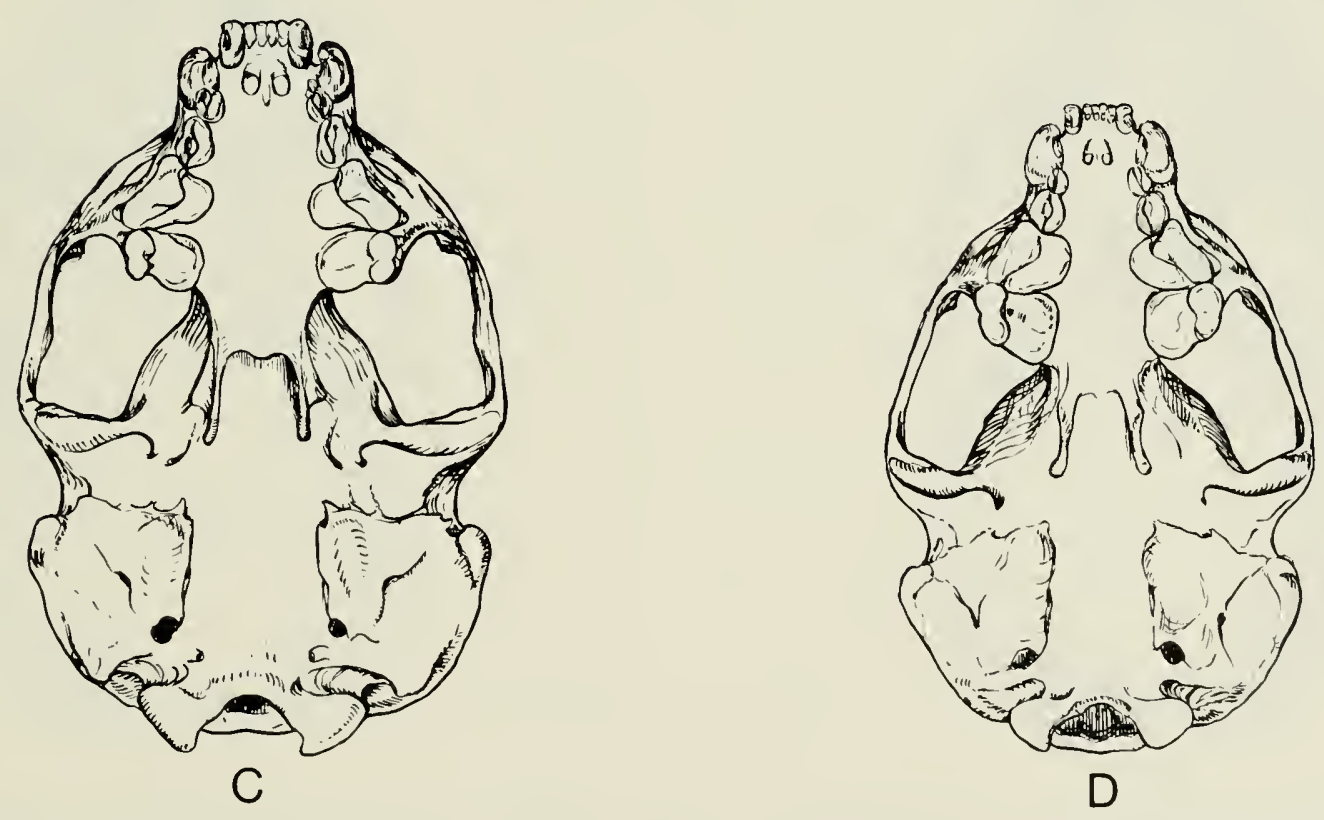

Fig. 29. Ventral view of otter skulls, details as in Fig. 28. A. L. provocax. B. L. provocax. C. L. felina. D. Amblony.x cinerea. 
898
808 


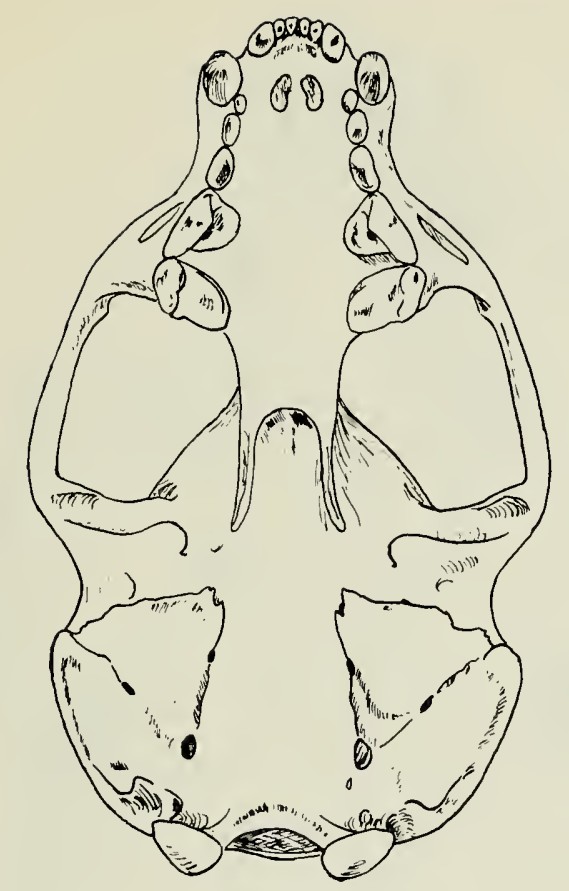

A
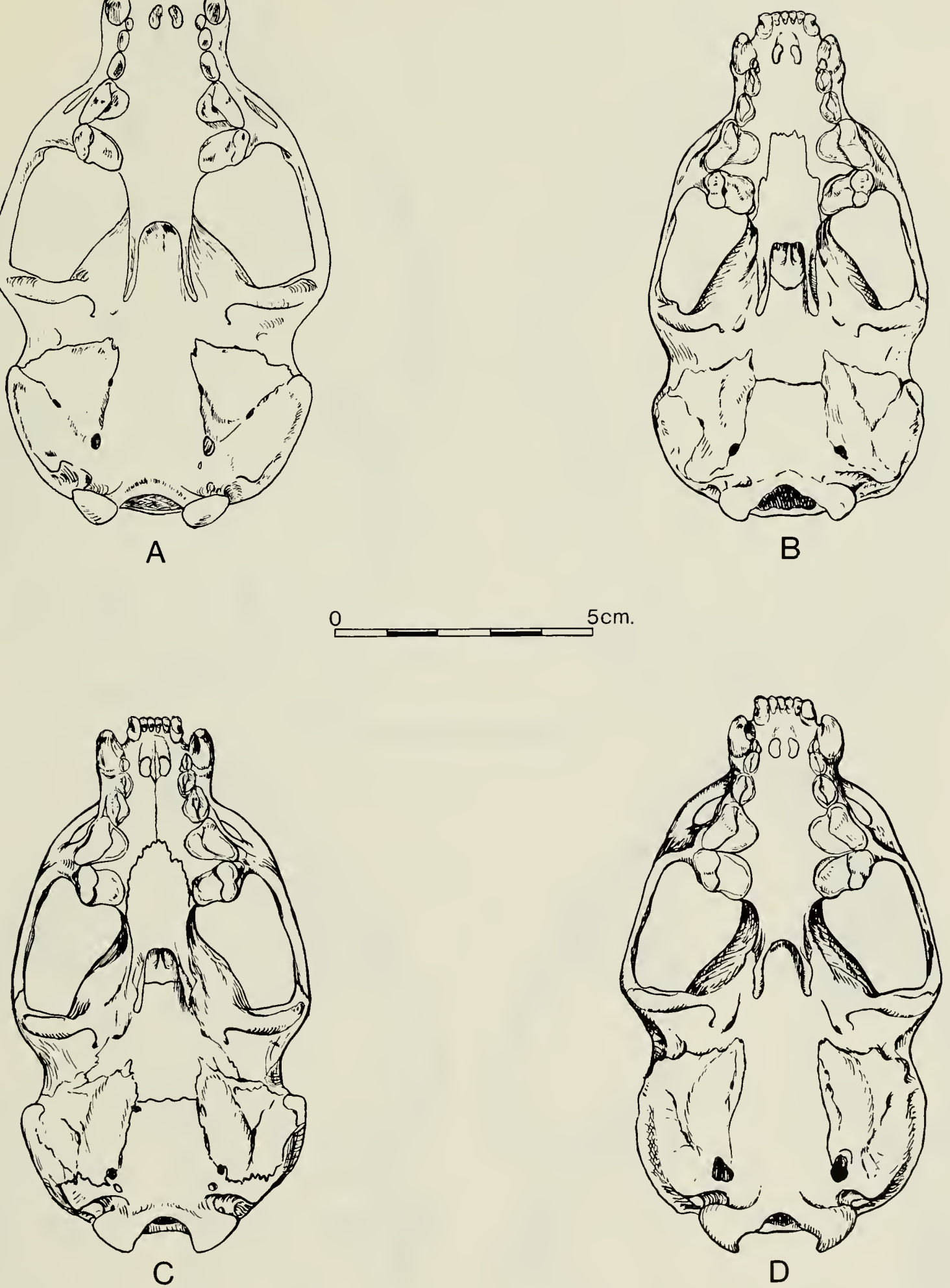

Fig. 31. Ventral view of otter skulls, details as in Fig. 30. A. L. lutra. B. L. lutra barang. C. L. sumatrana. D. L. maculicollis. 


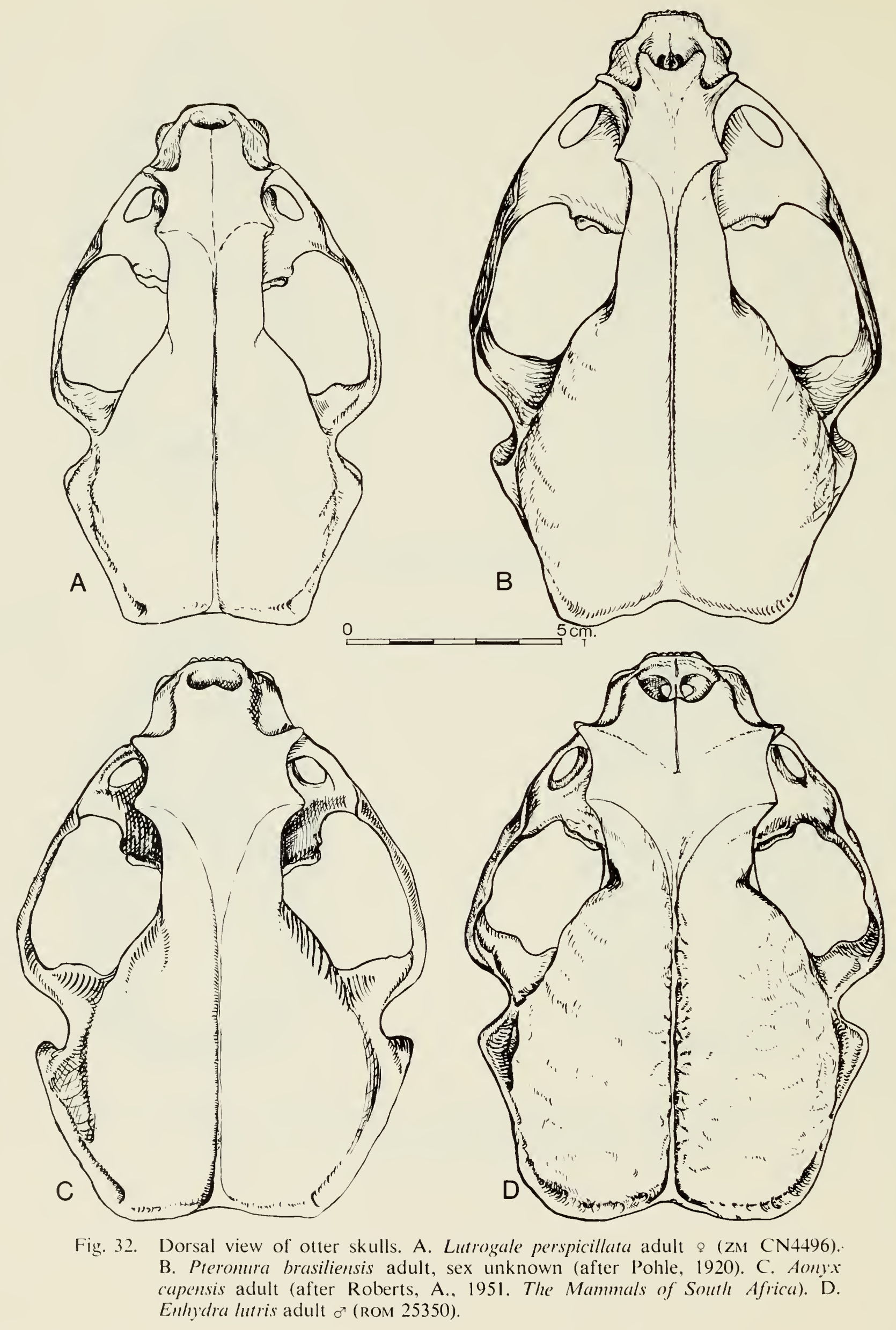



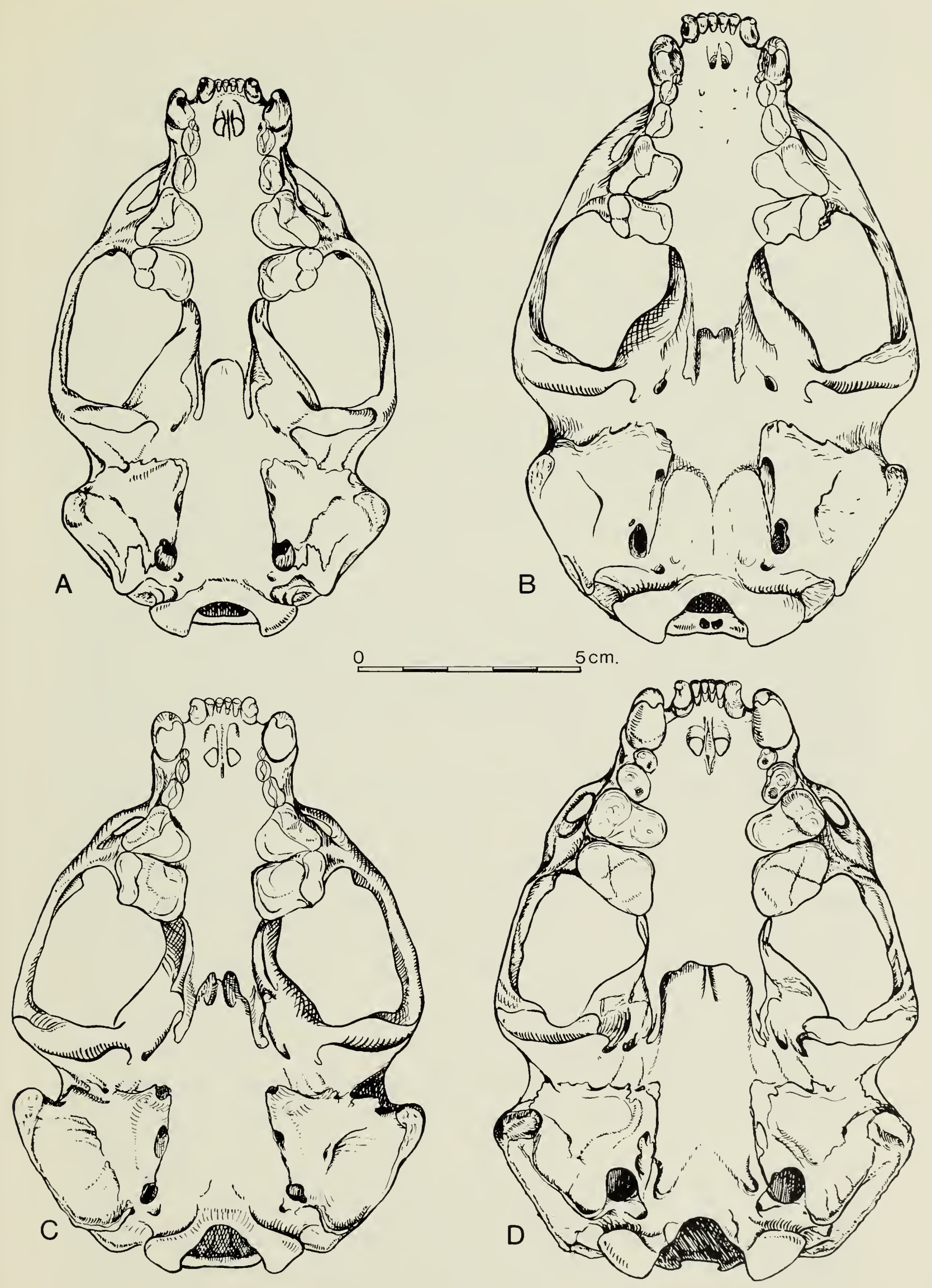

Fig. 33. Ventral view of otter skulls as in Fig. 32. A. Lutrogale perspicillata. B. Pteronura brasiliensis. C. Aonyx capensis. D. Enhydra lutris. 
broad. Aonyx also has relatively well developed postorbital processes (see Fig. $32 \mathrm{C}$ ). In contrast to those of the American river otters the skulls of Aonyx and Amblonyx are high. Dorso-ventral flattening of the skull can be observed in several unrelated mammalian groups that are adapted to an aquatic existence (e.g. Insectivora: Potamogale, Micropotamogale; Rodentia: Ichthyomys, Rheomys, Nilopegamys, Hydromys), but it is by no means a general rule. Pinnipeds do not exhibit dorso-ventral flattening, nor do Lutrogale, Pteronura, L. sumatrana and L. maculicollis, which have high and narrow skulls. The adaptive significance of these two types of skull is not clear, but it seems to hold true that the flattened skull is restricted to stream-dwelling forms which feed on fast moving prey. In the flattening of the skull the American forms resemble L. lutra with which they are ecologically equivalent.

A comparison of limb structure, which is not incorporated in the estimate of similarity except for the degree of webbing and claw development, reveals obvious differences between the two clawless otters and the American group. In the former the characters of the limb bones associated with a predominantly aquatic way of life, e.g., shortening of the limbs, curvature and distal expansion of the humerus, are much less pronounced. The weaker expression of these characters is correlated with a way of life which is much less aquatic than that of the fish-eating forms. The adaptive features of the limb and dentition are not correlated, but seem to have evolved independently (compare Enhydra, Aonyx and Potamotherium). In the limb bones the American river otters resemble their Palaearctic ecological counterpart L. lutra.

The separation of the American group and the Old World Lutra is especially evident in the dentition, which as was indicated above is generally more primitive in the latter. The skull in Old World Lutra tends to be narrower and has weak postorbital processes. The rather profound difference in the baculum of the American group and L. lutra (discussed above, Figs. 21 and 22) supports the separation. In other mustelids the baculum usually has a basic similarity in the species of one genus (cf. Didier, 1947, 1948; Burt, 1960).

The association of L. sumatrana and L. maculicollis agrees with Pohle's (1920) opinion that the two are closely related. Both have long, narrow and relatively high skulls, with weak postorbital processes. The bullae are relatively long and inflated. The dentition also is similar. The $\mathrm{P}^{4}$ in $L$. maculicollis may have a more expanded talon $(1 / 2-2 / 3$ of the lingual length of the tooth against $1 / 2$ in L. sumatrana). The parastyle in both species is set off from the anterior margin of the tooth. The $\mathbf{M}_{1}$ in both species has a basined talonid, although this is more pronounced in L. sumatrana. Their colour patterns also reveal a basic similarity; they are dark brown with little contrast between dorsal and ventral surface, the anterior part of the throat and chin is white, yellowish white or yellow, and the line of demarcation between dark and light areas is abrupt. In L. maculicollis the light throat has brown spots or is brown with light spots. Zoogeographic affinities between the Oriental and Ethiopian regions further suggest the likelihood that these species may have had a common origin (cf. Felis 
temmincki - F. auratus, Manis, tragulids, Herpestes, Pavo - Afropavo, etc.).

$L$. lutra is further removed from $L$. maculicollis and is closer to $L$. sumatrana. Similarities are especially evident in the dentition, but the skull of $L$. lutra is generally broader and flatter than that of $L$. sumatrana. However, young individuals and southern subspecies, such as L. l. barang, resemble $L$. sumatrana to a remarkable degree. The colouration of $L$. lutra is also more differentiated and lacks abruptly outlined markings on the throat.

An association of Lutrogale and Pteronura, although at a relatively low level, is contrary to current views. Lutrogale is usually associated with Lutra, whereas Pteronura is regarded as an isolated genus. Pohle (1920) expressed the opinion that Pteronura was derived from L. enudris, which does not deserve serious consideration. At present the possible relationship of Pteronura and the fossil L. (Satherium) sp. is being investigated (Bjork, pers. comm.). Compared to other Recent forms the closest similarity is with Lutrogale. Lutrogale in turn has its greatest similarity with the American group, as the similarity half-matrix shows, a fact not evident from the phenogram in Fig. 34.

Pteronura and Lutrogale have high and long narrow skulls, and similar dentitions with a $\mathrm{P}^{4}$ with an expanded talon and projecting parastyle. The teeth are high crowned. The orbits are placed far forward; the anterior border is situated between the $\mathrm{P}^{2}$ and $\mathrm{P}^{3}$ in Pteronura and at the $\mathrm{P}^{3}$ in Lutrogale. Pteronura has a much narrower interorbital area however. Both genera possess dorso-ventrally compressed tails, tapering in Lutrogale, but sword-shaped in Pteronura. The limbs of Pteronura are more specialized than those of Lutrogale, relatively short with well developed webs between the toes.

The association of Lutrogale and Pteronura with the Old World Lutra is, no doubt, influenced by their generally long, narrow and high skulls, but apart from these gross resemblances there is little similarity in detail and the association in one cluster in the phenogram probably does not reflect any particularly close phylogenetic relationship.

The isolated position of Enhydra is entirely in accordance with established taxonomic views and needs no elaboration. It may be pointed out, however, that Enhydra shows greatest similarity with Aonyx according to the distance coefficients half-matrix, a fact not brought out by the phenogram.

To what extent the similarity between the different forms is due to common ancestry or to convergence cannot be easily determined. The characters of the skull, dentition, and limbs used in this comparison are closely related to the animal's food-getting behaviour and respond to changes in selection pressure to meet the adaptive requirements of its ecological niche. In ecological vicars of different ancestry this may lead to close and deceptive resemblance. Elucidation of phylogenetic relationships between more remote forms would require more detailed and complete morphological comparison and palacontological evidence, as well as cytological, serological and behavioural comparisons. The clusters at 
higher levels are likely monophyletic. At the lower levels it becomes less probable that this is the case.

The next step is the delimitation of taxa on the phenogram. The cluster of $L$. canadensis represents the range of similarity within one species. The species cut-off should therefore be drawn below the base of the L. canadensis cluster (below 9.30). L. felina is also a good species, which leads to the conclusion that the line should be drawn above the 8.62 similarity level. The dissimilarity between $L$. provocax and the other large Neotropical forms is similar to the dissimilarity between $L$. felina and all other American forms, and much greater than the dissimilarity between the most divergent subspecies in L. canadensis. This suggests that the species cut-off should be drawn above the level of association of $L$. provocax and the L. annectens-enudris-platensis cluster. This narrows the possible level at which the species line should be drawn, to between 9.30 and 9.09 . Further examination of the phenogram shows that it should be drawn above the level of association of L. sumatrana and L. maculicollis (9.24) whose specific status can hardly be doubted. The species cut-off is therefore drawn between 9.30 and 9.24 .

The genus cut-off is drawn at the 8.50 level below the L. felina level and above the level where Amblonyx joins the American group, a level of similarity which marks the separation of major adaptive types (i.e., those with crushing and cutting dentition).

The species and genus lines thus drawn result in 12 species belonging to seven genera for the forms studied. This reduces the number of species by two (L. annectens, L. enudris and L. platensis become one species) and increases the number of genera by one (the American river otters are given generic status).

The creation of subgenera is unnecessary in view of the small size of the genera. Suprageneric division of the subfamily has been suggested several times. A division of Enhydra on the one hand and all other otters on the other was suggested by Gray (1865), who split the subfamily into two tribes Lutrina and Enhydrina and by Miller and Kellogg (1955), who created a separate subfamily Enhydrinae. Crusafont (quoted in Villalta Comella, 1952) suggested a division in three phylogenetic lines, the Lutroid, Aonichoid and Latachoid lines.

Separating Enhydra from the other Lutrinae at the subfamily level would serve no useful purpose and obscure the very real relationships that link Enhydra with the other otters. Tribal separation might be used to express its isolated position, but this should then also be applied to other highly specialized genera now extinct, such as Enhydriodon. The division into three phylogenetic lines proposed by Crusafont has a certain general validity in that it refers to three adaptive types, corresponding to Pohle's terms "Fischottern" and "Krebsottern," in which the Latachoids are merely a specialized branch of the latter. These adaptive types may or may not represent phylogenetic lines, and until more palaeontological evidence becomes available it may be best not to attempt any subdivision of the subfamily based on inadequate evidence. Another important consideration in drawing cut-offs at lower levels of the phenogram to mark the 
higher categories, is that of incorporating in the taxa the distortion present in increasing degrees if one moves down the phenogram. This brings us to an examination of the degree of distortion in the phenogram in Fig. 34. The correlation between the original distance coefficients and the cophenetic values obtained from the phenogram was relatively high $(\mathrm{r}=0.846)$ which indicates an acceptable representation of the information contained in the similarity half-matrix. Most of the distortion is present at the lower levels of the phenogram, as could be determined by comparing levels of association in the phenogram with the original values between the same OTU's in the half-matrix.

To see whether the distortion could be lessened by reducing the number of OTU's in the comparison, the number was reduced to the 12 species established in the phenogram. Values for the characters of the species were recalculated where necessary and a new similarity half-matrix and phenogram computed (Fig. 35). The correlation between the new phenogram and the similarity matrix produced a somewhat higher value $(r=0.885)$ than in the first case. To examine the distortion further, the values of association of phenogram II were plotted against the corresponding values of the half-matrix (Fig. 36). The graph and the mean deviation for three different levels from the $100 \%$ correlation line clearly show the increasing distortion at lower levels of the phenogram.

The position of the species in the second phenogram is similar to that of the first. The most obvious change is in the position of Lutrogale, now associated with the American group, which is more in accordance with the relationship in the half-matrix. The gap between Pteronura and Lutrogale and that between the Old World Lutra and the New World group is somewhat distorted.

Recognizing the same species, and applying the same criteria as before in drawing the genus cut-off, the same number of genera results.

The subspecies present special problems. The category is undoubtedly one of the most arbitrary and its use has been disputed (Wilson and Brown, 1953, and others). There is no generally established and accepted way to delimit subspecies (see Sokal, 1965). Mayr's (1942) definition of the subspecies could be applied to trivial and significant subdivisions of a species depending on the degree of taxonomic difference considered worthy of recognition by the individual taxonomist. Where a species range and variation are discontinuous recognition of subspecies is usually not a problem. Continuous range and gradual, almost unnoticeable intergradation presents a problem, and subdivisions can only be separated in a purely arbitrary way. Another consideration in the recognition of a formal subspecies is whether it is useful to the taxonomist (Simpson, 1961). This again may depend on the inclinations of the individual taxonomist. Personally I cannot escape the impression that the majority of subspecies recognized in the American river otters are not particularly useful.

L. canadensis has 20 listed subspecies, if we include L. mira which is listed as a species by Hall and Kelson (1959). L. lutra occupying an even more extensive range has only from six (Pohle, 1920) to 10 (Ellerman and Morrison-Scott, 1951). Does this reflect a greater variability of the 
American species, the greater discriminatory power of North American mammalogists, or a different concept of what constitutes a subspecies?

The phenogram cannot be used to determine the subspecies without careful consideration of some of the limitations imposed by the use of ratios in calculating the taxonomic distance. These could affect groups at the infraspecific levels in particular. As ratios within a species change with increase in size, two forms $\mathrm{A}$ and $\mathrm{B}$ of different size, for example, having the same slope but lying along a different allometric regression could have similar ratios, whereas a third form $\mathrm{C}$ lying along the same axis as $\mathrm{A}$ and being similar in size to B would have a ratio different from both. Species or supraspecific categories would be less affected because differences between them tend to be greater. Small sample size may also affect the results by yielding values not representative of the average condition in the population.

Where larger samples are used the clustering is largely in accordance with major groupings within the species. In L. canadensis, for instance, the following groups can be recognized at level 9.54:

(1) mira-vancouverensis - British Columbia pacifica group

(2) periclyzomae

(3) kodiacensis

(4) brevipilosus-pacifica-nexa-preblei-canadensis from the north Mississippi basin evexa-optiva-yukonensis group

(5) canadensis-degener group (chimo should probably be included here)

(6) lataxina-vaga-interior-texensis group.

These groups occupy geographically contiguous areas. The question arises whether they should be recognized as subspecies. The Pacific insular forms and the form from the British Columbian coast and Alaskan panhandle are undoubtedly the most distinct and can be distinguished from the others without too much difficulty. All other forms are closer to one another and are less easily separated.

The above groupings suggested by the phenogram, being based on a relatively large number of characters, probably reflect reasonably well the geographic subdivision of the species. On the other hand, presently recognized subspecies have been described on relatively few characters which, moreover, varied in number and nature from one to the next. As a result no consistent comparisons were obtained. It is, therefore, suggested that the number of subspecies could be reduced to the groups listed if formal recognition of subspecies is desired.

The two subspecies represented by very small samples should be considered. One of these, L. extera, is represented by one specimen. Most of its measurements fall within the normal range of variation of the adjacent mainland forms L. c. yukonensis and L. c. optiva (see Appendix 3), and its recognition as a separate subspecies seems unwarranted. The peripheral and relatively isolated geographical range of $L$. $c$. sonora, as well as its different proportions, suggests that it may represent a relatively welldifferentiated form that could be recognized. Larger samples are needed to confirm this. 


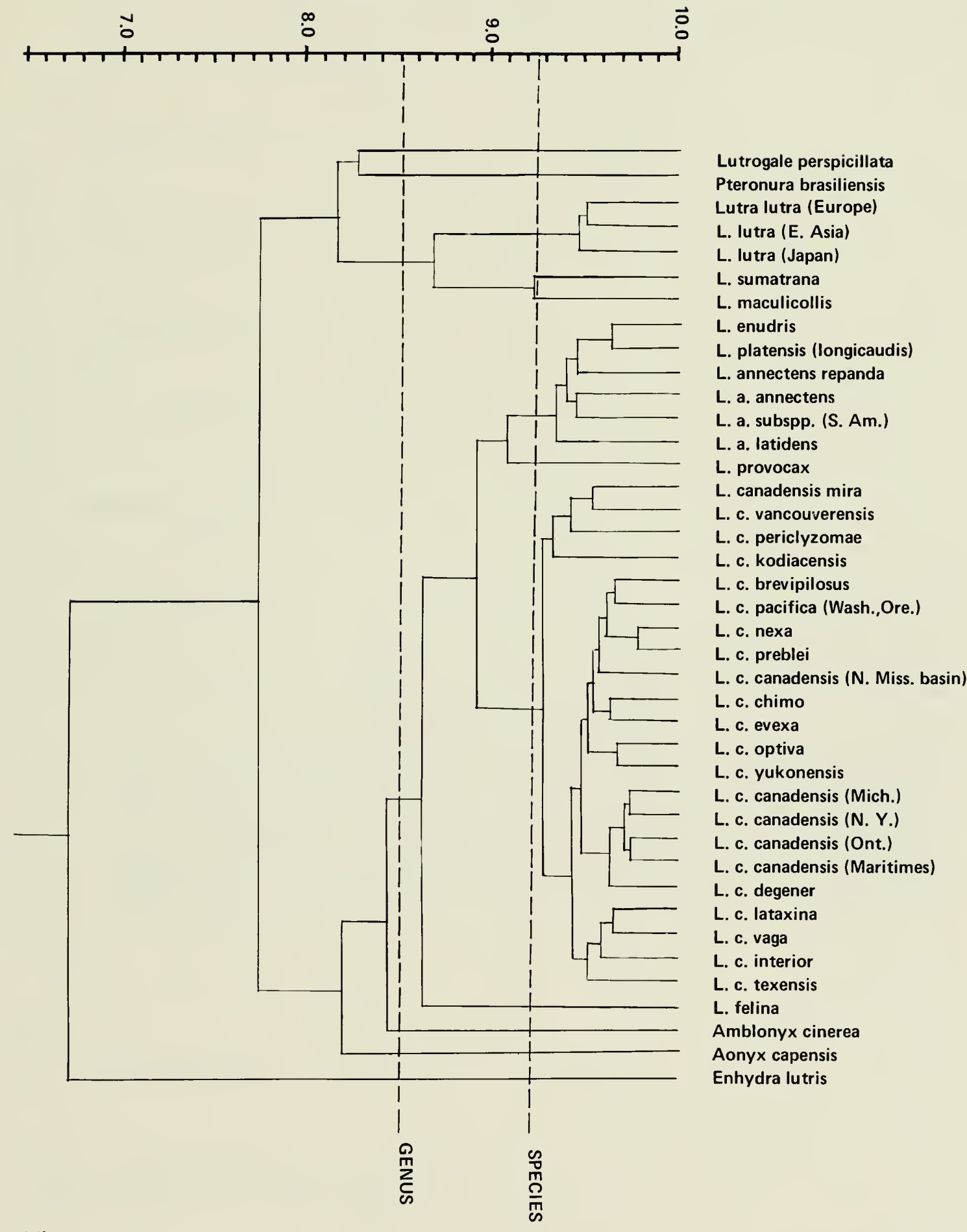

Fig. 34. Phenogram I. Similarity between samples of. Lutrinae based on 48 characters. 


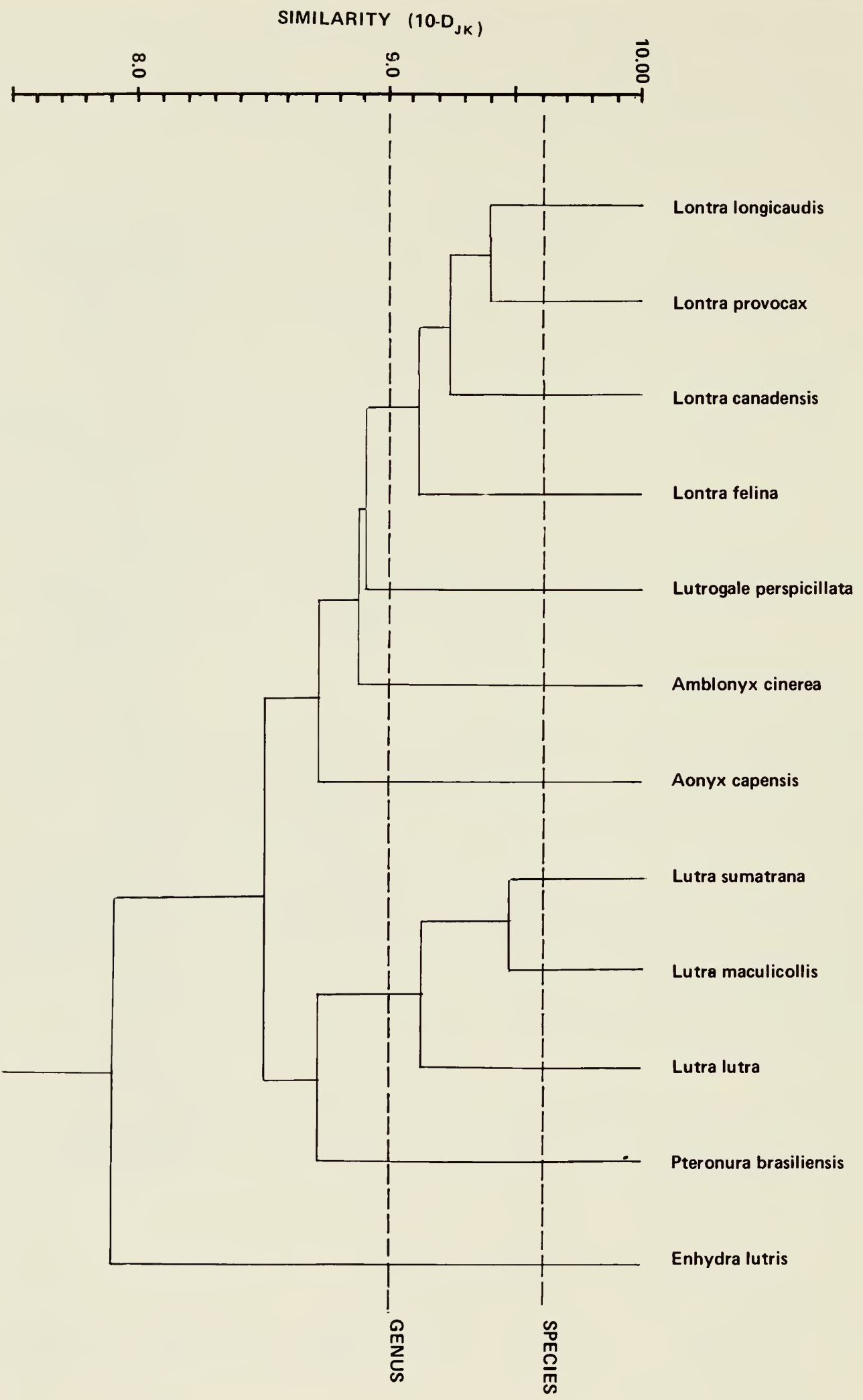

Fig. 35. Phenogram II. Similarity in 12 species of Lutrinae. 


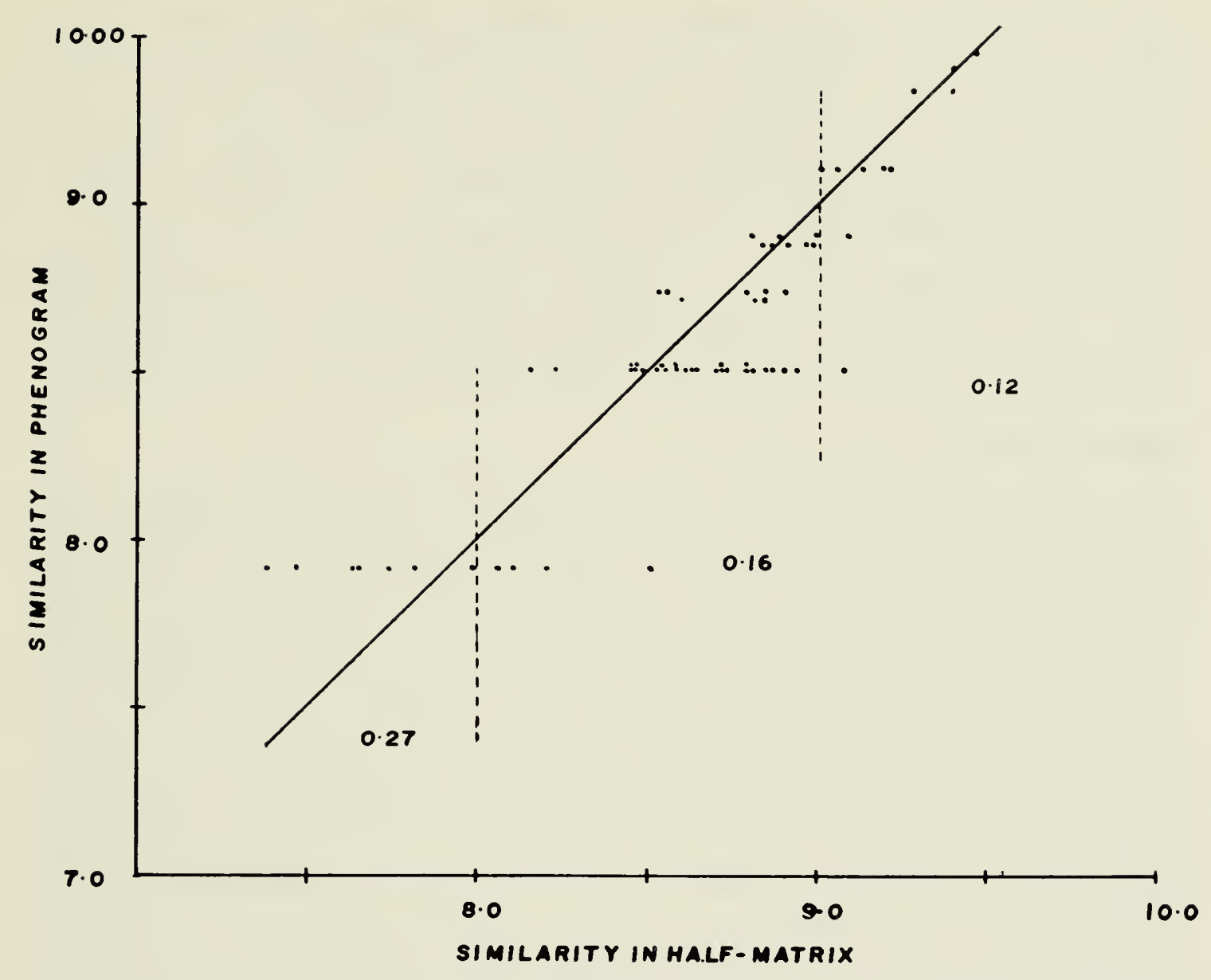

Fig. 36. The correlation of the similarities between taxa as expressed in the similarity half-matrix and the similarities between taxa expressed by phenogram II. The solid line represents perfect correlation $(r=1.0)$, the figures average deviations (10 - complement of the distance) from the ideal correlation in the $y$ direction for three different levels of the phenogram. The graph shows the increased distortion of the similarities at the lower levels of the phenogram.

\section{The Fossil Record}

A study of the relationships of Recent forms would not be complete if it did not include in its analysis the fossil evidence. Full understanding of relationships, in the evolutionary sense of the word, can only be achieved if the phenetic, cladistic and chronistic aspects of relationship are known (Sokal, 1966). The phenetic aspect of relationship deals with the degree of overall similarity between organisms, which may be due to recency of common descent (patristic resemblance) or to convergence (convergent resemblance). The cladistic aspect involves the branching of lineages, whereas the chronistic aspect brings in the element of time. These different aspects of relationship can be distinguished, but not separated from one another. 
In the preceding pages, the phenetic aspect in the relationship of the Recent forms was examined; in this section the emphasis shifts to an examination of the similarity in temporally sequential forms, in other words the cladistic and chronistic aspects of their relationships. In addition, the zoogeographical evidence presented leads naturally to a discussion of the probable origin and dispersal of the group. It may be stated at the outset, however, that we can hope to obtain only a very incomplete picture, due to the generally poor numerical representation of the Lutrinae in the fossil record and the usually fragmentary nature of the specimens.

\section{General Review}

The earliest known species of otter occurred in the upper Oligocene of Europe. This species, Potamotherium valetoni Is. Geoffr., is also the best known fossil species. Its skeleton is known in detail and much has been surmised about its probable way of life (Savage, 1957). Morphologically it combined a great number of primitive characters (e.g., in its dentition) with very specialized ones (limbs). It was highly specialized for an aquatic existence and is believed to have been an inhabitant of the extensive lagoons and lakes of Oligocene Europe. The dentition was characterized by well developed premolars in the upper jaw, $\mathrm{P}^{4}$ with a relatively small talon, a primitive $\mathrm{M}^{1}$ with parastyle obliquely antero-buccally from the paracone, the presence of an $\mathrm{M}^{*}$, the presence of $\mathrm{P}_{1}, \mathrm{P}_{3}$ and $\mathrm{P}_{4}$ with an accessory posterior cuspule, $M_{1}$ with the trigonid longer than the talonid; the metaconid is small and placed obliquely behind the protoconid, which is the largest cusp followed by the paraconid. The skull is relatively long and narrow, having a long postorbital constriction with parallel outlines and negligible postorbital processes.

The genus Potamotherium continues into the upper Miocene (Fahlbusch, 1967). One species, P. miocenicum (Peters), is known from this period (Thenius, 1949). It is known from skull fragments and teeth. It differs from its Oligocene relative in the larger dimensions of its mandible and dentition. The $\mathrm{P}^{4}$ has a more expanded talon, but in general shows the same primitive characters. Potamotherium is generally considered not to be ancestral to the later Lutrinae because of the advanced specialization of the limb bones of the Oligocene species. This, of course, does not preclude descent from earlier or less specialized Potamotherium-like forms.

A contemporary of Potamotherium in the Miocene of Europe is Paralutra which is known from the Lower to Upper Miocene (Roman and Viret, 1934; Kretzoi, 1951). One species is generally accepted, P. jaegeri (Fraas) (Helbing, 1936), although Kretzoi (1951) lists P. transdanubica from the Upper Miocene of Czakvar on the basis of $\mathrm{P}^{4}$ and $\mathrm{M}^{1}$. Paralutra is incompletely known from skull fragments, teeth, radius and ulna. It is more advanced than Potamotherium. The $\mathrm{P}^{4}$ has a relatively small deuterocone, and $\mathrm{M}^{1}$ has a relatively well developed mesiolingual cingulum and a flat expansion posteriorly (not a true hypocone according to Helbing, 1936). There is no $\mathrm{M}^{2}$. The lower carnassial has a relatively short and narrow talonid bearing a hypoconid and a weak indication of a small 
cusp behind it. The trigonid has a small metaconid placed back, the protoconid is somewhat larger than the paraconid, but the difference is less than in Potamotherium. The premolars are simple and do not possess accessory cuspules as in Potamotherium. Whether Paralutra is ancestral to Lutra ( sensu lato) is uncertain, although Piveteau (1961) believes this to be the case. The structure of $\mathrm{M}^{1}$, which is more expanded posteriorly than in recent $L$. lutra, and the absence of a posterior cuspule on $\mathrm{P}^{4}$ in all known specimens would appear to testify against this.

At the end of the Miocene and the beginning of the Pliocene there appear rather large and highly specialized forms of the genus Enhydriodon. The $\mathrm{P}^{4}$ in this form carries additional cusps on the talon, and the teeth in general are broadened and adapted for crushing rather than cutting. Similar adaptations are also present in Vishnuonyx and Sivaonyx from the same period. Sivalictis from the upper Siwaliks is known only from an isolated $\mathrm{M}^{1}$ and is questionably lutrine (Pilgrim, 1932). From the European Pliocene is known "Lutra" hessica (Lydekker) which according to Pohle (1920) is an Aonyx, and according to Pilgrim (1932) a Sivaonyx. It is known from a mandibular fragment; the $\mathrm{M}_{1}$ has a large metaconid, its circumference being approximately equal to that of the protoconid and its height somewhat less. The occlusal outline of the tooth is strongly rounded and the position of the paraconid is medial to the protoconid and metaconid. The talonid is basined and the entire tooth has a bilaterally symmetrical appearance. "Lutra" bravardi, another form from the Upper Pliocene of Europe, is known from an upper jaw (Viret, 1954); Pohle (1920) considered it to be an Aonyx on the basis of $\mathbf{M}^{1}$ which is broadened as in the Recent Aonyx species, although the talon of the $\mathrm{P}^{4}$ is relatively small. A large form from the Upper Pliocene of China is "Lutra" aonychoides, which, as the name indicates shows many similarities with Recent Aonyx (Zdansky, 1924, Teilhard de Chardin and Leroy, 1945). It is known from the anterior portion of a cranium and a mandible with upper and lower dentition, which leave little doubt of its affinities with Aonyx. All the above Pliocene forms show adaptations which can be loosely described as Aonyx-like, that is, a broadening of the teeth generally and lowering of the cusps. Lutra-like forms are much rarer in the fossil record. L. sinerizi (Villalta Comella, 1952) from the Upper Pliocene of Spain (Villarroya) is known only from a mandibular ramus with teeth and was considered to be close to Lutra lutra. However Viret (1954) has shown that the mandible did not belong to an otter, but to Enhydrictis. It is distinguished from Lutra by the greater depth of the ramus and the smaller metaconid of the $\mathbf{M}_{1}$, which is also placed back farther than in Recent forms.

It is in the Pliocene that the Lutrinae first appear in the North American record with a poorly known Lutrine from the Lower and Upper Pliocene (Repenning in Hopkins, 1967) and Lutravus halli from the Upper Pliocene (Furlong, 1932). The first of these forms is based on some fragmented mandibles and two $M_{1}$ (MacDonald, 1956, Repenning, unpublished data). Although most certainly a true lutrine, the exact position of this form will remain uncertain until more complete material comes to 
light. The $\mathrm{M}_{1}$ is more advanced than in Lutravus due to the more anterior position of the metaconid, which is situated as in Recent forms. The $\mathrm{M}_{1}$ resembles that of Lutra lutra but has a noticeably broader talonid.

Lutravus resembles L. lutra somewhat, but is generally more primitive. The $\mathrm{P}^{4}$ has a less expanded talon, and $\mathrm{M}^{1}$ is rectangular without a distinct hypocone, but the distolingual part is expanded to form a shelf-like surface. The $M_{1}$ is relatively narrow, with a short talonid, a small metaconid which is placed farther back than in Recent forms and a protoconid somewhat higher than the paraconid. The $\mathrm{P}_{4}$ is simple and lacks a posterior cuspule. Furthermore, Lutravus has a longer rostrum than Recent forms. In most of these characters Lutravus resembles Paralutra more than any other form. Paralutra, however, has a parastyle on $\mathrm{P}^{t}$ that projects less anteriorly, relative to the deuterocone, than in Lutravus, and $\mathrm{M}^{1}$ is somewhat more expanded distolingually than in Lutravus. Its buccal cingulum is more like that of Lutra than of Lutravus.

From the Upper Pliocene and the Lower Pleistocene large American otters such as Lutra (Satherium) spp. are known. The teeth resemble those of the American river otters and of Pteronura in a general way. The $\mathrm{P}^{t}$ has an expanded talon extending along the entire length of the tooth and possesses a cuspule between the protocone and the anterior part of the paracone. The lower carnassial is rather broad and has a cuspule immediately posterior to the metaconid, sealing off the talonid basin. The $\mathrm{M}^{1}$ has the protocone surrounded by the hypocone cingulum. The skull has well developed postorbital processes, a relatively long interorbital constriction, a relatively small braincase and wide zygomatic arches. An undescribed mustelid is known from the late Blancan which, according to Repenning (in Hopkins, 1967), is an Enhydriodon. This constitutes the first record of this genus in the New World if the identification is correct.

There are a few other Pliocene forms that may be mentioned, but which are not very relevant in determining the origin of Recent forms. Lutra affinis Gervais from the Middle Pliocene of France is known only from a very inadequate description. The type is lost and no illustrations exist. Lutra bressana Depéret, also from the middle Pliocene of France, is known from fragments of limb bones and cannot be compared with the other forms.

The Pleistocene of Europe has revealed at least three genera, Cyrnaonyx, Nesolutra and Lutra. Lutra is represented by the Recent species L. lutra, which appeared as a relatively late immigrant in the European fauna (Thenius, 1949; Kurtén, 1968) and by L. simplicidens in the lower Pleistocene (Thenius, 1965). Cyrnaonyx has Aonyx-like adaptations (Helbing, 1935), and is an Aonyx according to Kurtén (1968). Nesolutra is known from parts of its appendicular skeleton, which reveal it to have been a more advanced aquatic type than recent Lutra (Bate, 1935).

Another European Pleistocene form is "Lutra" reevei Newton known from a single lower carnassial from early Pleistocene marine deposits. Pohle (1920) considered reevei to be ancestral to Enhydra and derived reevei in turn from $L$. hessica. Mitchell (1966) has recently shown a reevei ancestry of Enhydra to be untenable. The tooth displays a high 
degree of specialization paralleling that seen in Enhydra but it is contemporary with Enhydra and geographical remoteness of the two forms further suggests an independent origin. The trigonid is triangular with the paraconid the smallest cusp; the protoconid and metaconid are approximately the same size, but the latter is somewhat higher. All cusps are low and rounded. The talonid is approximately the same length as the trigonid and is basined; the hypoconid is blunt, and the talonid is lingually bordered by a high rounded cingulum. The tooth must have belonged to a lutrine with specializations similar to those of Enhydra and could well have been derived from a form such as L. hessica or similar less specialized Aonyxlike otters. Enhydra can be traced to the early Pleistocene (Leffler, 1964; Mitchell, 1966).

From the Lower Pleistocene of southern Asia (Pinjor), Lutra palaeindica Falc. and Cautl. resembles the Recent L. sumatrana-L. lutra group, in particular L. lutra barang ( $=L$. intermedia Pohle) according to Pohle (1920). L. melina from the upper Pleistocene of China (Pei, 1934) is not a Lutra, but a primitive member of the Melinae, Melodon (Teilhare de Chardin and Leroy, 1945).

From the early Pleistocene of China Teilhard de Chardin and Piveteau (1930) described an otter, L. licenti, which in all principal characters resembles the Recent American river otters. Otters of this type first appear in the American fossil record during the middle of the Pleistocene (Yarmouth and Illinoian) which suggests a possible invasion during the Kansan, a period during which the Bering land bridge was in existence (Hopkins, 1967) and there was a wave of new immigrants from the Palaearctic. L. lutra makes its first appearance in Europe late in the Pleistocene (Eemian) (Kurtén, 1968); in China only Recent finds are known (Teilhard de Chardin and Leroy, 1945). This suggests that L. lutra achieved its wide Palaearctic distribution relatively late in the Pleistocene and in all probability dispersed from the Oriental region, as an Ethiopian or Nearctic origin is unlikely. This invasion, by L. lutra, of the Palaearctic region may be related to the disappearance of the Lutra licenti from China after it had invaded North America. Possible subsequent invasion and establishment of L. lutra in North America, provided that it could have reached the Bering bridge in time, may have been unsuccessful due to the presence of the ecologically equivalent American forms. At what time otters first appeared in South America is uncertain, but most reported records appear to be Upper Pleistocene and the animals are not distinguished from Recent forms occurring there now (Ameghino, 1916; Pohle, 1920). Simpson (1950) regarded otters as Pampean (Pleistocene) immigrants to South America, and Hershkovitz (1966) stated that they belong to the most recent stratum of immigrants (Pleistocene).

The history of the Lutrinae in Africa is not well known. Enhydriodon is known from the Middle Pliocene and Aonyx and Lutra from the Pleistocene (Hopwood and Hollyfield, 1954). Africa was cut off from Eurasia during much of the Tertiary and the oldest mustelid carnivores date from the Pliocene of Egypt (Wadi Natrun, Cooke, 1963, 1968). We may assume that the Lutrinae also invaded that continent during that time. 
The Ethiopian region has its closest faunal relationship with the Oriental region (Darlington, 1957), and this suggests an Oriental origin of the African Lutrinae. Before taking a closer look at the fossil forms that belong to the American group some of the general observations and conclusions concerning the fossil record of the subfamily may now be summarized.

All the evidence suggests the origin of the subfamily to be Eurasia, from which it first invaded North America in the Pliocene, whence it migrated to South America in the Pleistocene. The Lutrinae probably reached Africa in the Pliocene.

Most of the known Tertiary forms cannot be directly linked to any Recent forms, although they do indicate in a general way what ancestral forms must have been like. Only at the beginning of the Quaternary do forms appear that could be considered as directly ancestral to Recent forms (e.g., L. palaeindica and L. licenti).

Generally speaking the fossil record shows two types of dentition to have been present. One shows specialization towards cutting (the more primitive condition) and the other one towards crushing (the more advanced condition). A third type characterized by reduction is represented by the Recent African genus Paraonyx. Between the two extreme types there are, of course, all degrees of intermediacy. Even the most primitive Lutrine dentition (e.g., that of Potamotherium valetoni) has crushing components, although the most advanced crushing type adaptation (Enhydra) has lost its shearing components completely. This distinction of two basic adaptive morphological types does not necessarily mean that the two types form two phylogenetic lines. To the contrary, there is some evidence that the adaptation for crushing may have arisen several times in different lineages from the more primitive condition, as was the case in the Felidae with its analogous machairodont and feline adaptive types (Thenius, 1967). We may cite the example of L. reevei and Enhydra which both developed similar adaptations in the $M_{1}$ but are not, in all probability, closely related. In the Recent American group two opposite trends are illustrated by $L$. provocax where the tendency is towards broadening of the dentition and $L$. felina where the opposite is the case. The Recent forms can be arranged on the basis of the specialization of their dentition with L. sumatrana, L. maculicollis and L. lutra at one end, having the most primitive dentition; and Amblonyx cinerea, Aonyx capensis and Enhydra lutris in that order, with the most specialized dentition, at the other end. The American group along with Lutrogale and Pteronura are intermediate, having relatively well developed crushing surfaces, but at the same time retaining their shearing components.

The adaptations in the limbs are not correlated with dental specialization but depend on the degree of aquatic specialization of the form.

\section{The fossil forms of the American group of river otters}

L. licenti was described in 1930 by Teilhard de Chardin and Piveteau from the anterior part of a skull and a nearly complete lower jaw dating from the Sanmenian of Nihowan (Lower Pleistocene). Three other 
specimens in the Frick collection (AMNH) were later referred to this species (Teilhard de Chardin and Leroy, 1945). As these particular specimens were never studied carefully, they are therefore described in detail here.

The material consists of two skull fragments (AMNH 50577, 50578) and a left mandibular ramus (AMNH 50579) (Figs. 37 and 38). Specimen 50577 consists of the anterior part of a cranium containing a nearly complete dentition. The left $\mathrm{P}^{4}$, the canines and the right $\mathrm{P}^{1}$ are broken, and the right premaxilla and its incisors are missing. The remaining teeth are undamaged. Dorsally the rostrum, nares, interorbital areas, orbits, left infraorbital foramen and part of the postorbital constriction are present. Specimen 50578 is a palate with complete left upper dentition; the right side is broken at the level of $\mathrm{P}^{4}$, which is damaged, but the remaining teeth are undamaged. Dorsally the specimen consists of part of the maxillae, premaxillae and nasals, but the entire specimen is somewhat distorted by pressure. The mandible of 50579 is broken posterior to $M_{2}$. $I_{1}$ is missing and the crown of the $\mathrm{M}_{2}$ is broken off.

The specimens originated from "Tsao Chuang, $18 \mathrm{mi}$. south of Shou Yang City, southeastern Shansi," China. The site is regarded to be about the same age as that of the type locality, Nihowan, i.e., Sanmenian (Lower Pleistocene). Remains of Felis (Lynx), Ursus, Canis, Hyaena, Elephas and Gazella were associated with the specimens at the Tsao Chuang site (Tedford, unpublished data).

Teilhard de Chardin and Piveteau (1930) concluded after their study of the type that $L$. licenti showed the greatest degree of similarity with $L$. lataxina ( $=L$. canadensis). They did not compare the specimens with Lutrogale, which is the only Recent Asian form with teeth resembling those of the American group of river otters. A more detailed descriptive and numerical comparison with a larger number of Recent and fossil forms of the American group will be attempted here, and in addition Lutrogale will be considered.

In the upper dentition, the incisors and canines of $L$. licenti are similar to the Recent forms, although incisors are possibly somewhat heavier. The $\mathrm{P}^{1}$ and $\mathrm{P}^{2}$ of the former are somewhat larger, but the position of the $\mathrm{P}^{1}$ is as in the Recent forms; the $\mathrm{P}^{3}$ has a less well developed cingulum. The $\mathrm{P}^{4}$ is very similar to those in Recent species of the platensis group and differs from Lutrogale perspicillata, which has a parastyle that projects more relative to the anterior border of the talon. The paracone is similar to that of Recent forms; the anterior cutting edge of the paracone is pronounced as in many Recent forms (e.g. L. enudris). The anterior lingual edge of the paracone continues in the cingulum of the talon as in Recent forms. The talon of $\mathrm{P}^{4}$ in the specimens from Tsao Chuang is not as expanded as in the type and does not quite touch $\mathrm{M}^{1}$, but this variation is no more than that observed in Recent species. Because of this less expanded talon the specimens show only the anterior concavity of the talon; the posterior concavity, present in the type and separated from the anterior one by a threshold, is not present and is represented only by a shelf-like surface. This also is within the normal range of variation of Recent American species. 

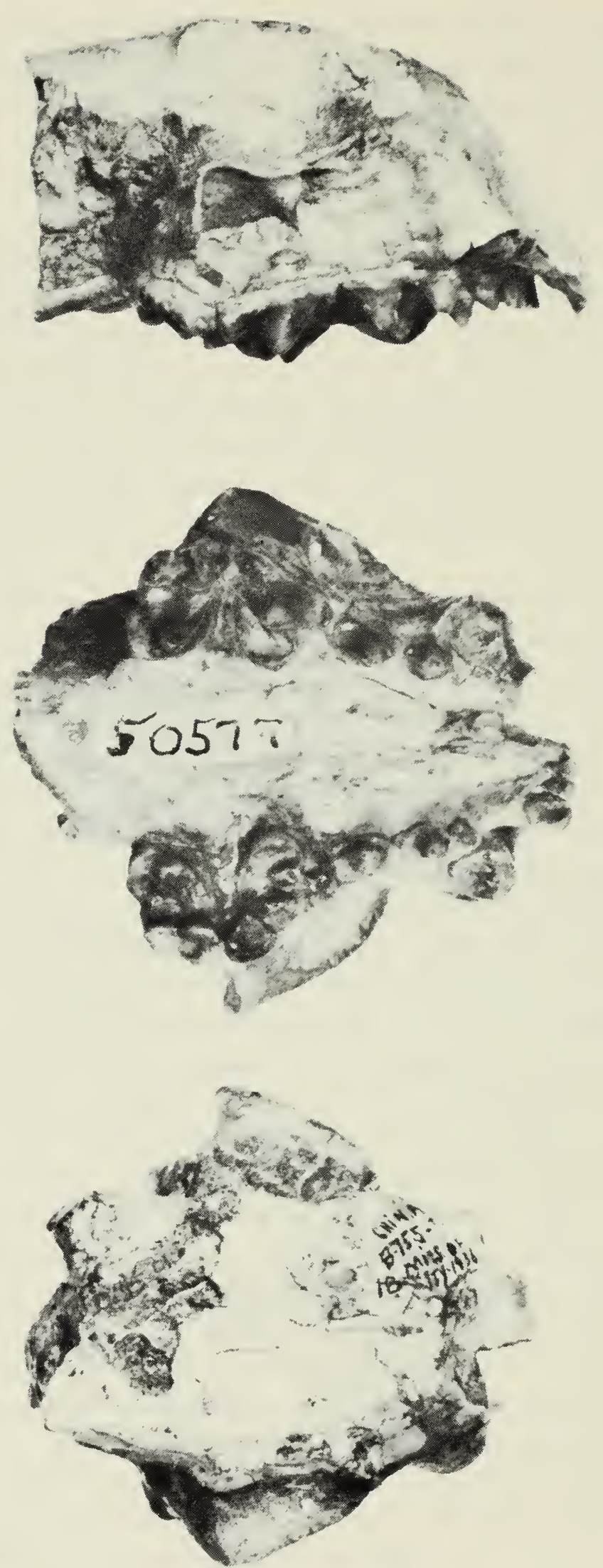

Fig. 37. Part of a skull of $L$. licenti of the Sanmenian of Tsao Chuang, China (AMNH 50577), lateral, ventral and dorsal view. Approximately natural size. 

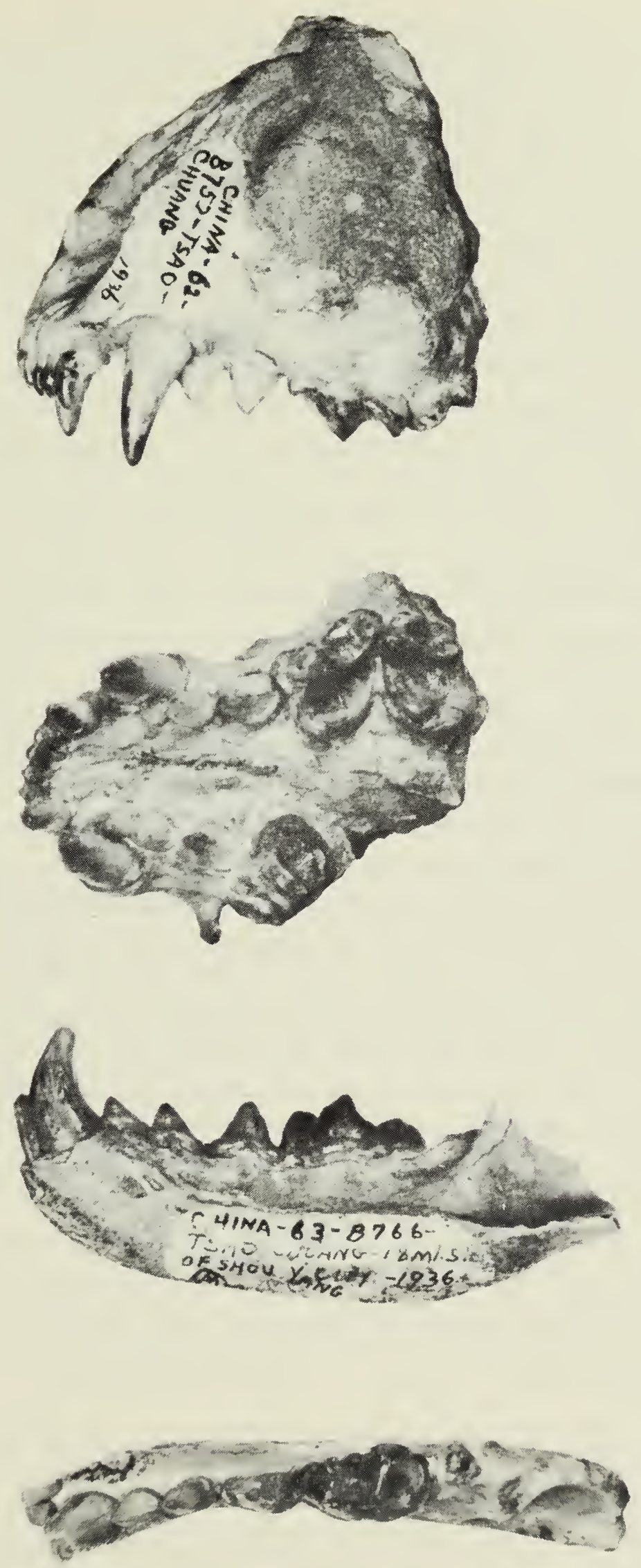

Fig. 38. Partial skull of $L$. licenti (upper $\mathrm{M}$ MNH 50578), lateral and ventral views, mandible from the same locality (lower AMNH 50579). Approximately natural size. 
The $\mathrm{M}^{1}$ is a distinctive tooth in $L$. licenti and differs from its homologue in any of the American forms. The protocone is distinctly marked from the hypocone, which is not flattened and expanded as in Recent forms. The protoconal ridge runs from the paracone lingually to the peak of the protocone, thence buccally to the base of the metacone giving the trigon the shape of a heart. The mesiolingual cingulum of the protocone is little developed. Paracone and metacone are as in Recent forms, but the parastyle is more distinct. The buccal cingulum of the metacone is as in Recent forms. The angle between the buccal axes of $\mathrm{P}^{4}$ and $\mathrm{M}^{1}$ is the same as in Recent forms, approximately $130^{\circ}$.

The lower premolars are similar to those of Recent forms, with $\mathrm{P}_{2}$ and $\mathrm{P}_{3}$ perhaps a little heavier; the $\mathrm{P}_{4}$ has a rather weak posterior accessory conulid, which is more pronounced in the type. This character is also rather variable in Recent forms and is sometimes lacking.

$M_{1}$ resembles that tooth in Recent forms; the buccal cingulum of the talonid is relatively little developed, similar to the condition in L. annectens and L. enudris. Height of the trigonid is as those in Recent forms of the American group, but lower than that of Lutrogale. The anterior edge of the paraconid is convex, not straight or at a slant as in the Recent forms. The paraconid is somewhat lower than the protoconid. The talonid is approximately as long as the trigonid; it is not basined but slants lingually and has a low lingual cingulum.

The skull has a short broad rostrum, as short as in a L. annectens (ROM 35057 ) of the same size, and a rather broad interorbital width. The postorbital processes are broken off, but judging from the break surface they were weaker than in a similar sized specimen of L. annectens (ROM 35057). The postorbital constriction is as wide as the interorbital width and has parallel borders. In profile the facial part of the skull is convex like that of $L$. annectens. The posterior palatine foramina are situated farther forward (at the level of the $\mathrm{P}^{3}$ ) than in most Recent forms. At the level of the anterior border of the $\mathrm{P}^{4}$ there is a faint indication of the palatal suture which is rounded as in L. canadensis.

There can be little doubt about the relationship of $L$. licenti with the American group of river otters. The specimens from Tsao Chuang are generally similar to the type, but in addition to the differences already pointed out, they are characterized by their greater dimensions (see Appendix 3, and Figs. 9-14).

The first record of an otter of the American type from North America is L. rhoadsi Cope, from the Port Kennedy Cave, dating probably from the Yarmouth interglacial (Hibbard, 1958). The species is based chiefly on two mandible fragments (Cope, 1899; Hall, 1936). Pohle (1920) regarded $L$. rhoadsi as a synonym of $L$. c. lataxina. He united it with $L$. canadensis as he felt the distinctive characters were either "pathological" (transverse position of $\mathrm{P}_{4}$ ) or within the range of variation of that species. He placed it in lataxina mainly on geographical grounds and on the assumption of the relatively young age of the deposit. Hall (1936) concurred with Pohle's judgement. It seems to me that, in view of the inadequate material and the relative great age of the deposit, a subspecific 
designation is rather dubious. Because of the similarity between L. rhoadsi and $L$. canadensis we may assume them to be conspecific.

L. parvicuspis Gidley and Gazin from the Cumberland Cave, Maryland, of Illinoian or Sangamon age (Hibbard, 1958) is based on a broken and crushed skull with the principal cheek teeth present on both sides. According to Hall (1936) L. parvicuspis cannot be distinguished from L. canadensis and he synonymized it with $L$. c. lataxina, while Gidley and Gazin (1938) maintained that it is probably distinct from the modern species. Examination of the specimen during the course of this study and comparison of measurements with comparable measurements of Recent forms confirmed Hall's (1936) opinion on its conspecificity with L. canadensis (see Appendix 3; Figs. 9-12). However, a subspecific name should probably not be applied for the reasons given above for $L$. rhoadsi.

L. iowa Goldman, from Wright County, Iowa, of uncertain age but assumed to be Pleistocene, was considered by Goldman (1941) to be more closely related to $L$. annectens than to L. canadensis. A re-examination and comparison of the specimen was undertaken to test the validity of his conclusion.

The rostrum of $L$. iowa is relatively broad and short and more similar to the condition in a similarly sized $L$. annectens than in $L$. canadensis, which tends to have a somewhat longer rostrum. The interorbital width is relatively broad ( $87.3 \%$ of the rostral width); it is not as broad as $L$. canadensis (90.4\%-93.2\% of rostral width) but broader than most $L$. annectens (82-86.4\% of the rostral width). In a similar sized L. annectens (ROM 35057) the interorbital width was $81 \%$ of the rostral width. The width of the postorbital constriction in L. lowa is $67.7 \%$ of its interorbital width, against $70.5 \%$ in similarly sized L. annectens, and $68.4 \%$ in similarly sized L. canadensis. The orbito-nasal length in L. iowa is $61 \%$ of the width of the postorbital processes and 78.5-90\% in L. canadensis and $70-72.8 \%$ in $L$. annectens. The profile of the facial part of the cranium of L. iowa is straight as in L. canadensis and not convex as in L. annectens. The profile of the nasals is also similar to that of $L$. canadensis.

In addition, $\mathrm{P}^{3}$ is much wider than in L. canadensis and its width-length relationship is more similar to that in L. enudris and L. platensis. The relationship of the width to buccal length in the $\mathrm{P}^{4}$ is similar to that of $L$. canadensis, but the tooth is much larger and similar in size to those of $L$. provocax, L. annectens and some L. platensis. The relationship of the talon length of the $\mathrm{P}^{4}$ to its buccal length is just within the range of $L$. canadensis, but more like those of $L$. annectens and L. provocax (see Fig. 10 ), although the topography of the talon is more like that of $L$. canadensis. The lingual length of the $\mathrm{M}^{1}$ in relation to the greatest diameter of that tooth is similar to that in L. canadensis, except for the much greater size of the tooth, which is greater than in any of the Neotropical forms, except L. provocax (see Fig. 11 ). The buccal length of the $\mathrm{M}^{1}$ is relatively smaller than in L. canadensis and more similar to that of the Neotropical forms (Fig. 12). The combination of small buccal and large lingual length gives the tooth a shape similar to that of $L$. provocax. The buccal length of the $\mathrm{P}^{4}$ in relation to the molar-premolar series is similar to that in $L$. canadensis and L. provocax. 
In summary L. iowa appears to present a combination of characters linking it with most Recent American species, but not clearly allying it to any single one. It is probably best to retain the species $L$. iowa in view of this. Lack of stratigraphic information makes it difficult to speculate about its possible ancestral relationship to the large American forms.

Fossil remains from Fossil Lake, Oregon, and from Melbourne and Vero, Florida, all from the Upper Pleistocene, are referable to the Recent L. canadensis.

\section{Summary}

Results from the numerical and morphologic comparisons show the existence of four relatively well differentiated forms in Pohle's platensis group. Analysis of overall similarity based on the coefficient of taxonomic distance suggests that these forms are distinct at the specific level. The four species that can be recognized correspond to the Nearctic Lutra canadensis, the Neotropical L. annectens-enudris-platensis group, L. provocax and L. felina.

Variation at the infraspecific level suggests that the number of subspecies now recognized in $L$. canadensis is excessive and only approximately half of those now recognized are valid. Moreover, many of the current subspecies are ill-defined and based on trivial differences, and synonomy into fewer groups more accurately characterizes geographical variation found in the species.

Geographical variation within the L. annectens-enudris-platensis group is inadequately known. Their described subspecies are often based on one or a few specimens, which do not adequately document the variation in local geographical populations, and a single species is proposed. The oldest name available for the new combination of annectens, enudris and platensis is longicaudis Olfers, 1818 (Hershkovitz, 1959). For the present it seems best to recognize the former species as subspecies of longicaudis. They occupy clearly defined and semi-isolated subdivisions of the species' range and are taxonomically well-defined. Variation within these three groups should be investigated. L. provocax and L. felina appear to be monotypic.

Comparison of Pohle's platensis group with other members of the subfamily shows its distinctness. The relationship to the Old World Lutra, in particular L. lutra, appears not to be as close as was previously assumed (Pohle, 1920). The morphological differences distinguishing the American

Lutra from the L. lutra are approximately the same as those distinguishing L. lutra and Lutrogale. The analysis of overall similarity of the subfamily suggests that the platensis group should be elevated to generic rank. Generic status for the group is accepted here, although confirmation of this status by evidence from other sources is highly desirable. Lontra Gray, 1843 is available for the genus. A tentative rearrangement of the American otters is summarized as follows: 
Geographic Races of Nearctic River Otters, Lontra canadensis

Previous Arrangement

Suggested New Arrangement

(Hall and Kelson, 1959)

Lutra c. canadensis (Schreber, 1776)

Lutra c. chimo Anderson, 1944

Lutra c. degener Bangs, 1898

Lutra c. brevipilosus Grinnell, 1914

Lutra c. evexa Goldman, 1935

Lutra c. extera Goldman, 1935

Lutra c. nexa Goldman, 1935

Lutra c. optiva Goldman, 1935

Lutra c. pacifica Rhoads, 1895

Lutra c. preblei Goldman, 1935

Lutra c. yukonensis Goldman, 1935

Lutra c. interior Swenk, 1920

Lutra c. lataxina Cuvier, 1823

Lutra c. texensis Goldman, 1935

Lutra c. vaga Bangs, 1898

Lontra c. canadensis (Schreber)

Lontra c. pacifica (Rhoads)

Lutra c. kodiacensis Goldman, 1935

Lontra c. kodiacensis (Goldman)

Lutra c. periclyzomae Elliot, 1905

Lontra c. periclyzomae (Elliot)

Lutra mira Goldman, 1935

Lutra c. vancouverensis Goldman, 1935

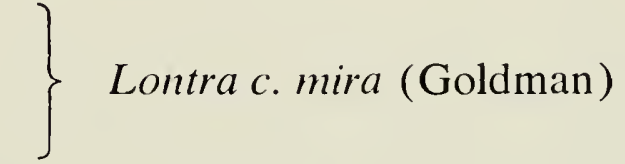

Lutra c. sonora Rhoads, 1898

Lontra c. sonora (Rhoads)

Species and Geographic Races of Neotropical Otters

Previous Arrangement (Pohle, 1920) Suggested New Arrangement

Lutra platensis Waterhouse, 1838

Lontra longicaudis longicaudis (Olfers)

Lutra enudris enudris Cuvier, 1823

Lutra e. mitis Thomas, 1908

Lutra e. incarum Thomas, 1908

Lontra longicaudis enudris (Cuvier)

Lutra annectens annectens Major, 1897

Lutra a. colombiana J. A. Allen 1904

Lutra a. emerita Thomas, 1908

Lutra a. latidens J. A. Allen, 1908

Lutra a. parilina Thomas, 1914

Lutra a. repanda Goldman, 1914

Lutra provocax Thomas, 1908

Lontra provocax (Thomas)

Lutra felina (Molina) 1782

Lontra felina (Molina) 
The genus can be traced back to at least the beginning of the Pleistocene, and its origin was most probably in Eurasia, from where the oldest fossils are known. It may have invaded North America during the Kansan glaciation. The first fossil remains from continental North America are tentatively dated from the Yarmouth interglacial (Hibbard, 1958), shortly after or during which they may have migrated into South America.

At present all species except $L$. provocax and $L$. felina are allopatric and all except L. felina, a littoral marine species, are probably ecological equivalents. The large species are morphologically similar and have differentiated comparatively little, reflecting their relatively recent evolution. $L$. provocax, more similar to other large Neotropical species than to the Nearctic L. canadensis, probably evolved from the former after invasion of the Patagonian subregion, which is characterized by a high proportion of endemics that testify to its relative isolation from other subregions of Neotropica. L. felina, the most distinct species, probably evolved from a stream-dwelling species that adapted to a marine environment after isolation in coastal habitats as a consequence of progressive aridity in middle latitudes of South America's west coast.

\section{Key to the genera of the subfamily Lutrinae}

1. Hindfeet flipper-like, forefeet short with toes enclosed by common skin; three upper premolars and two lower incisors.

Hindfeet not flipper-like and distinct digits present; usually four upper premolars (occasionally three) and three lower incisors.

2. Feet webbed at least to the proximal end of digital pad and bearing well developed claws; skull usually flattened dorso-ventrally or high and elongated.

Feet not webbed or with reduced webs, claws reduced or absent; skull broad and high.

3. Size large, total length to 2 metres, fur short, tail dorso-ventrally flattened with lateral keels broader in the middle than at the base; skull with postorbital constriction tapering anteriorly.

Size small to medium; tail rounded, or if dorso-ventrally flattened, tapering evenly from its base; skull with sides of postorbital constriction parallel or tapering posteriorly.

4. Short smooth fur; tail dorso-ventrally flattened tapering to a point, skull high and elongate, postorbital constriction relatively long with sides parallel.

Medium to long fur; tail rounded; skull usually dorso-ventrally flattened, postorbital constriction short, outline variable.

5. Postorbital processes poorly developed, the distance between them less than the distance from tip of postorbital process to distal end of the median suture of nasals.

Postorbital processes well developed, the distance between them greater than the distance from tip of postorbital process to distal end of the median suture of nasals. 
6. Webs on forefeet to the proximal end of third phalanx, on hindfeet to proximal end of digital pad; claws reduced but present on all toes; vibrissae stiff; teeth relatively stout, high crowned; skull small $(<90 \mathrm{~mm})$, broad and high.

Amblonyx

Webs on forefeet absent or extending to distal end of second phalanx; claws absent on forefeet, on hindfoot small nail-like claws present on third or fourth digit; vibrissae soft; teeth well developed and low crowned or reduced; skull large $(>100 \mathrm{~mm})$, broad and high.

7. Webs on forefeet extending to distal end of first phalanx, on hindfeet to distal end of second phalanx; superciliary and upper genal vibrissae present, cheek teeth large and broad, buccal length of $\mathrm{M}^{1}>10 \mathrm{~mm}$, greatest diameter of $M^{1}>14 \mathrm{~mm}$, length of $M_{1}>15 \mathrm{~mm}$.

Aonyx

Webs not present on forefeet and extending to proximal end of second phalanx on hindfoot, superciliary and upper genal vibrissae lacking, size of cheek teeth reduced, buccal length of $M^{1}<10 \mathrm{~mm}$, greatest diameter of $\mathrm{M}^{1}<14 \mathrm{~mm}$, length $\mathrm{M}_{1}<15 \mathrm{~mm}$.

Paraonyx

\section{Key to the species of the genus Lontra}

1. Size small (total length usually $<100 \mathrm{~cm}$ ), rhinarium bare with straight dorsal border; skull small (basal length usually $<90 \mathrm{~mm}$ ), postorbital constriction short, dorsal outline of its lateral borders arciform; $\mathrm{P}^{4}$ wih parastyle projecting in occlusal view; $\mathrm{M}_{1}$ long and narrow, buccal cingulum of talonid not well developed, $\mathrm{P}^{1}$ usually absent.

\section{L. felina}

Size large (total length usually $>110 \mathrm{~cm}$ ); rhinarium bare or partially furred, skull relatively larger (basal length usually $>90 \mathrm{~mm}$ ); dorsal outline of lateral borders of postorbital constriction usually straight, $\mathrm{P}^{4}$ with parastyle not prominent, usually lying on a line with anterior edge of talon, $M_{1}$ broad, usually with well developed buccal cingulum of the talonid, $\mathrm{P}^{1}$ usually present.

2. Ventral surface of webs furred, rhinarium bare with obtuse triangular dorsal projection.

L. canadensis

Ventral surface of webs naked or nearly so; rhinarium without obtuse triangular projection.

3. Anterior dorsal profile of skull straight, premaxillae in profile precipitous, talon of $\mathrm{P}^{4}$ with anterior hemispheric depression surrounded by rounded rim.

L. provocax

Anterior dorsal profile of skull convex, premaxillae in profile not precipitous, talon of $\mathrm{P}^{4}$ without anterior hemispheric depression.

L. longicaudis 


\title{
Synopses
}

\author{
Genus Lontra Gray
}

Lontra Gray, Feb. 1843. Ann. Mag. Nat. Hist., series 1, XI, p. 118. Type species: L. canadensis

Latax Gray, Feb. 1843. Ann. Mag. Nat. Hist., series 1, xI, p. 119. Type: L. lataxina

Lataxina Gray, 1843. List of the ... mammalia in the . . British Museum. p. 70. Type: Lataxina mollis Gray (= Lutra lataxina G. F. Cuvier)

Lataxia Gervais, 1885. Histoire naturelle des mammifères ... 2, p. 118 (renaming of Latax Gray)

Nutria Gray. June, 1865. Proc. Zool. Soc. London, p. 128. Type: L. felina

DIAGNosis. Small to medium-sized river otters, front and hind feet webbed and toes bearing well developed claws, rhinarium variously bare or furred, four abdominal mammae.

Skull dorso-ventrally flattened, mastoid width greater than length of braincase, mastoid processes prominent, either hook-like and directed ventrally or extending laterally, post-orbital processes well developed and width between them greater than length from tip of postorbital process to distal end of median nasal suture and exceeding interorbital width by more than $6 \mathrm{~mm}$, postorbital constriction broad, rarely less than $15 \mathrm{~mm}$ wide.

$\mathrm{P}^{4}$ with expanded talon, extending nearly along entire length of tooth, $\mathrm{M}_{1}$ broad with expanded buccal cingulum at talonid.

Baculum relatively large, with ventral urethral groove, distal end curved dorsally, tip not bifid.

\section{Lontra canadensis (Schreber)}

DIAGNOSIS. Ventral surface of webs hairy, cornified skin of plantar pads rough, rhinarium bare with obtusely triangular dorsal projection, colour of pelage usually darker than in L. longicaudis.

Dorsal anterior profile of skull straight, mastoid processes relatively weak, lambdoidal crest curves dorsally, bullae relatively short and flat, interorbital width relatively great, facial part of skull longer than in L. longicaudis.

Talon of $\mathrm{P}^{t}$ expanded posteriorly, talon length relative to buccal length of tooth greater than in other species, posterior margin of talon usually in contact with anterior margin of $\mathrm{M}^{1}, \mathrm{M}^{1}$ with lingual and buccal length approximately equal, occlusal outline of $\mathrm{M}^{1}$ approaching square, $\mathrm{M}_{1}$ broad, both carnassials smaller relative to premolar-molar series than in other species of genus.

Baculum large, 14 pairs of ribs.

Lontra canadensis canadensis (Schreber)

Mustela lutra canadensis Schreber, 1776. Die Saügethiere... Theil 3. Heft 18, PI. 126b, type locality. Eastern Canada.

Lutra degener Bangs, 1898. Proc. Biol. Soc. Washington, 12, p. 35.

Lutra canadensis degener Pohle, 1920. Arch. Naturgesch. 85. Abt. A, No. 9 , p. 94.

Lutra canadensis chimo Anderson, 1945. Ann. Rept. Provancher Soc. Nat.

Hist., Quebec, p. 59.

DIAGNosis. Smallest and darkest subspecies. Skull small, postorbital constriction usually with parallel outlines, bullae relatively flat. bucco-lingual width of $\mathrm{P}^{t}$ less than $10 \mathrm{~mm}$, mean about $9 \mathrm{~mm}$, mean mesiodistal length of $\mathrm{M}_{1}$ less than $14 \mathrm{~mm}$.

Distribution. Eastern Canada and adjacent areas of the United States. 
Lontra canadensis lataxina (G. F. Cuvier)

Lutra lataxina G. F. Cuvier 1823. Dictionnaire des sciences naturelles . . 27, p. 242, type locality, South Carolina.

Lataxina mollis Gray, 1843. List of the ... mammalia in the ... British Museum, p. 70.

Lutra hudsonica vaga Bangs, 1898, March. Proc. Boston Soc. Nat. Hist. 28, p. 224.

Lutra canadensis lataxina J. A. Allen, 1898, November 10. Bull. Amer. Mus. Nat. Hist., 10, p. 460.

Lutra canadensis vaga J. A. Allen, 1898, November 10. Bull. Amer. Mus. Nat. Hist., 10, p. 460.

Lutra canadensis interior Swenk, 1920. Univ. Nebraska Studies, 18, p. 2.

Lutra canadensis texensis Goldman, 1935. Proc. Biol. Soc. Washington, 48, p. 184.

DIAGNOSIS. Somewhat larger and lighter in colour than L. c. canadensis. Basal length of skull averages greater than $100 \mathrm{~mm}$ in males, somewhat less in females; bullae relatively inflated, bucco-lingual width of $\mathrm{P}^{4}$ usually greater than $9 \mathrm{~mm}$, mesiodistal length of $\mathrm{M}_{1}$ averages more than $14 \mathrm{~mm}$.

Distribution. The United States east of the Rocky Mountains.

\section{Lontra canadensis pacifica (Rhoads)}

Lutra hudsonica pacifica Rhoads, 1898. Trans. Amer. Philos. Soc. n.s. 19, p. 429, type locality, Lake Keechelus, Washington.

Lutra canadensis pacifica, J. A. Allen, 1898, November. Bull. Amer. Mus. Nat. Hist. 10, p. 460.

Lutra canadensis brevipilosus Grinnell, 1914. Univ. California Publ. Zool., 12, p. 306.

Lutra canadensis preblei Goldman, 1935. Proc. Biol. Soc. Washington, 48, p. 178.

Lutra canadensis optiva Goldman, 1935. Proc. Biol. Soc. Washington, 48, p. 179.

Lutra canadensis yukonensis Goldman, 1935. Proc. Biol. Soc. Washington, 48, p. 180.

Lutra canadensis extera Goldman, 1935. Proc. Biol. Soc. Washington, 48 , p. 181.

Lutra canadensis evexa Goldman, 1935. Proc. Biol. Soc. Washington, 48, p. 182.

Lutra canadensis nexa Goldman, 1935. Proc. Biol. Soc. Washington, 48. p. 182.

DIAGNOSIS. Larger on the average than lataxina, much larger than canadensis, lighter in colour than both, bullae flatter than in lataxina, more inflated than in canadensis; width of $\mathrm{P}^{4}$ and length of $\mathrm{M}_{1}$ average less than in lataxina but more than in canadensis.

Distribution. The western United States, western and northern Canada and Alaska.

\section{Lontra canadensis mira (Goldman)}

Lutra mira Goldman, 1935. Proc. Biol. Soc. Washington, 48, p. 185. type locality, Prince of Wales Island, Alaska.

Lutra vancouverensis Goldman, 1935. Proc. Biol. Soc. Wash., 48, p. 186.

Lutra canadensis vancouverensis Dalquest, 1948. Univ. Kansas Publ., Mus. Nat. Hist., 2, p. 210. 
DIAGNOSIS. Largest of the subspecies, basal length of skull averages greater than $105 \mathrm{~mm}$, buccolingual width of $\mathrm{P}^{4}$ averages $10 \mathrm{~mm}$ or more, mesiodistal length of $\mathrm{M}_{1}$ averages more than $14.5 \mathrm{~mm}$.

Distribution. Coastal British Columbia including Vancouver Island; southeastern Alaska and offshore islands.

Lontra canadensis periclyzomae (Elliot)

Lutra periclyzomae Elliot, 1905. Proc. Biol. Soc. Washington, 18, p. 80. type locality, Queen Charlotte Islands, British Columbia.

Lutra canadensis periclyzomae Heller, 1909. Univ. California Publ. Zool. 5, p. 262.

DIAGNOSIS. Large, but slightly smaller than preceding form, further differs from it by narrower skull and very flat bullae, width of $\mathrm{P}^{4}$ smaller $(9.6 \mathrm{~mm})$. length of $\mathrm{M}_{1}$ also smaller $(14.3 \mathrm{~mm})$.

Distribution. Queen Charlotte Islands.

Lontra canadensis kodiacensis (Goldman)

Lutra canadensis kodiacensis Goldman, 1935. Proc. Biol. Soc. Washington, 48, p. 180, type locality, Kodiak Island.

DIAGNOSIS. Medium sized, skull with narrow and relatively high braincase. bullae flat, width of $\mathrm{P}^{4}$ averages approximately $9 \mathrm{~mm}$, length of $\mathrm{M}_{1} 14 \mathrm{~mm}$.

DISTRIBUTION. Kodiak Island.

Lontra canadensis sonora (Rhoads)

Lutra hudsonica sonora Rhoads, 1898, September. Trans. Amer. Philos.

Soc., n.s. 19, p. 431, type locality, Yavapai Co.. Arizona.

Lutra canadensis sonora J. A. Allen, 1898, November. Bull. Amer. Mus. Nat. Hist., 10, p. 460.

DIAGNOSIS. Large, skull long but relatively narrow, bullae flat, bucco-lingual width of $\mathrm{P}^{4}$ and length of $\mathrm{M}_{1}$ somewhat less than in mira, $\mathrm{M}^{1}$ nearly square. Distribution. Colorado River system.

\section{Lontra longicaudis (Olfers)}

DIAGNOSIS. Similar to L. canadensis in size but sexual dimorphism more pronounced. Ventral surface of webs not hairy, cornified skin of plantar pads relatively smooth, rhinarium bare or furred.

Anterior dorsal profile of skull convex, lambdoidal crest, if present, extending posteriorly, roof-like, mastoid processes well developed with tendency to extend laterally, bullae longer and more inflated than in other species of genus, width of postorbital constriction less than in L. canadensis, interorbital width relatively narrow, facial part of skull shortened, braincase broad and flat.

Talon of $\mathrm{P}^{4}$ expands less far posteriorly than in L. canadensis, usually not touching $\mathrm{M}^{1}, \mathrm{M}^{1}$ with smaller mesiodistal dimensions relative to bucco-lingual dimension, $\mathbf{M}_{1}$ less broad than in L. canadensis or L. provocax, both carnassials relatively large in relation to premolar-molar series.

Baculum smaller than in L. canadensis, pairs of ribs 15 or 16 , rarely 14 .

Lontra longicaudis longicaudis (Olfers)

Lutra longicaudis Olfers, 1818. W. L. Eschwege's Journal von Brasilien, vol. 15, Heft 2, p. 233, type locality, Brazil.

Lutra platensis Waterhouse, 1838. Proc. Zool. Soc. London, p. 60.

Lutra solitaria Wagner, 1842. Arch. Naturg. vIII, p. 358.

Lutra latifrons Nehring, 1887. S. B. Ges. Naturf. Berlin, p. 23. 
Lutra platensis Pohle, 1920. Arch. Naturgesch. 85 (Abt. A No. 9) p. 101.

Lutra platensis Cabrera, 1958. Rev. Mus. Arg. Cien. Nat. Tomo 4, p. 273. DIAGNOSIs. Rhinarium naked, upper border straight or curving slightly ventrally, colour dark brown, wool hair on ventral surface light brown, not tinged with orange.

Distribution. Paraná River system.

Lontra longicaudis enudris (G. F. Cuvier)

Lutra enudris Cuvier, 1823. Dictionnaire des Sciences Naturelles XXvII, p. 242.

Lutra insularis Cuvier, 1823. Dictionnaire des Sciences Naturelles xxviI, p. 243.

Lontra enhydris Gray, 1865. Proc. Zool. Soc. London, p. 125.

Lontra brasiliensis Gray, 1865. Proc. Zool. Soc. London, p. 125.

Lutra latifrons Nehring, 1887. S. B. Ges. Naturf. Berlin, p. 23.

Lutra incarum Thomas, 1908. Ann. Mag. Nat. Hist. 8 ser. 1, p. 392.

Lutra mitis Thomas, 1908. Ann. Mag. Nat. Hist. 8 ser. 1, p. 393.

Lutra enudris mitis, Pohle, 1920. Arch. Naturgesch. 85 (Abt. A. No. 9), p. 100.

Lutra enudris incarum Pohle, 1920. Arch. Naturgesch. 85 (Abt. A, No. 9), p. 101.

Lutra enudris enudris Cabrera, 1958. Rev. Mus. Arg. Cien. Nat. Tomo 4, p. 271.

Lutra incarum Cabrera, 1958. Rev. Mus. Arg. Cien. Nat. Tomo 4, p. 273. DIAGNOSIS. Rhinarium variable, from hairy uninterrupted median band of hair of various widths to bare with median dorsal and ventral hairy projections, some similar to that of $L$. l. longicaudis, colour lighter (reddish brown) than in longicaudis, wool hair on ventral surface usually tinged with orange, tendency for light coloured spots in throat and chest area, teeth large, bullae inflated.

Distribution. Amazon River, Orinoco and smaller neighbouring river systems east of the Andes.

Lontra longicaudis annectens (Major)

Lutra annectens Major, 1897. Zool. Anz. 20, p. 142.

Lutra colombiana J. A. Allen, 1904. Bull. Amer. Mus. 20, p. 452.

Lutra latidens J. A. Allen, 1908. Bull. Amer. Mus. 24, p. 660.

Lutra emerita Thomas, 1908. Ann. Mag. Nat. Hist. 8 ser. 1, p. 390.

Lutra parilina Thomas, 1914. Ann. Mag. Nat. Hist. 8 ser. 14, p. 59.

Lutra repanda Goldman, 1914. Smithson. Collect. Vol. 63, No. 5, p. 3.

Lutra annectens latidens Pohle, 1920. Arch. Naturgesch. 85 (Abt. A, No. 9), p. 95.

Lutra annectens repanda Pohle, 1920. Arch. Naturgesch. 85 (Abt. A, No. 9), p. 96.

Lutra annectens colombiana Pohle, 1920. Arch. Naturgesch. 85 (Abt. A. No. 9), p. 97.

Lutra annectens emerita Pohle, 1920. Arch. Naturgesch. 85 (Abt. A. No. 9), p. 97.

Lutra annectens parilina Pohle, 1920. Arch. Naturgesch. 85 (Abt. A. No. 9), p. 98.

Lontra mesopetes Cabrera, 1924. Bol. Real. Soc. Española Hist. Nat. Madrid, 24, p. 52. (Its position here is doubtful.)

Lutra annectens mesopotes (sic) Miller and Kellogg, 1955. Bull. U.S. Nat. Mus., 205, p. 766. 
Lutra annectens colombiana Cabrera, 1958. Rev. Mus. Cien. Nat. Tomo 4, p. 271.

Lutra annectens parilina Cabrera, 1958. Rev. Mus. Arg. Cien. Nat. Tomo 4, p. 271.

DIAGNOSIs. Rhinarium with acute upward projection, colour similar to enudris, but underfur dull brownish not tinged with orange, skull flatter and broader than longicaudis and enudris, length of $\mathrm{P}^{4}$ and $\mathrm{M}_{1}$ relative to premolar-molar series smaller than in previous two subspecies.

Distribution. Central America, Mexico and South America west of the Andes, south to Peru.

\section{Lontra provocax (Thomas)}

Lutra provocax Thomas, 1908. Ann. Mag. Nat. Hist. (8) ser. 1, p. 391, type locality, Lake Nahuel Huapi, Patagonia.

Lutra provocax Pohle, 1920. Arch. Naturgesch. 85 (Abt. A, No. 9), p. 103.

Lutra provocax Cabrera, 1958. Rev. Mus. Arg. Cien. Nat. Tomo 4, p. 273.

DIAGNOSIS. Ventral surface of webs not hairy, cornified skin of plantar pads rougher than in L. longicaudis; rhinarium bare with acute median dorsal projection, pelage dark brown dorsally, much lighter ventrally.

Profile of skull straight dorsally; profile of pre-maxillae precipitous; mastoid processes well developed, extending laterally; lambdoidal crests as in $L$. longicaudis, braincase narrower and facial part of skull longer than in L. longicaudis, bullae small and flat.

Teeth large; $\mathrm{P}^{4}$ broad, talon characteristically with bowl-shaped anterior depression surrounded by broad rounded rim; $\mathrm{M}^{1}$ greatly expanded lingually, $\mathrm{M}_{1}$ very broad, buccal cingulum of talonid much expanded, approximately one third of total width of talonid.

Distribution. Chile and southern Argentina, formerly as far north as the Rio Negro and east to the Atlantic.

\section{Lontra felina (Molina)}

Mustela felina Molina, 1782. Sagg. Stor. Nat. Chili, p. 284, type locality Chile.

Mustela (Lutra) chilensis Kerr, 1792. Anim. Kingd. Mamm., p. 172.

Lutra chilensis Bennet, 1832. Proc. Zool. Soc. London, p. 1.

Lutra californica Gray, 1837. Mag. Nat. Hist. (Charlesworth), 1, p. 580.

Lutra brachydactyla Wagner, 1841. Suppl. Schreber's Saügeth., 2, p. 261.

Lutra peruensis Gervais, 1841. Mammifères, Voyage autour du monde sur la corvette "La Bonité", 1, p. 15.

Nutria felina Gray, 1865. Proc. Zool. Soc. London, p. 128.

Lutra felina Pohle, 1920. Arch. Naturgesch. 85 (Abt. A, No. 9), p. 104.

Lutra felina Cabrera, 1958. Rev. Mus. Arg. Cien. Nat. Tomo 4, p. 272.

DiAGNosis. Smallest species in the genus, tail and feet relatively short, ventral surface of webs with scattered hairs, rhinarium bare, dorsal border straight, pelage brown with very little contrast between dorsal and ventral surfaces.

Skull small, basal length $78-90 \mathrm{~mm}$, profile of dorsal part straight, bullae short and flat.

Teeth relatively large, $\mathrm{P}^{1}$ frequently absent, $\mathrm{P}^{4}$ with projecting parastyle noticeable in occlusal view, $M_{1}$ long and narrow.

distribution. Pacific coast from northern Peru to Cape Horn. 


\section{Acknowledgments}

I am indebted to the following persons and institutions for the loan of specimens or for permission to examine material in their collections: Drs. S. Anderson, M. C. McKenna, R. H. Tedford, and R. G. Van Gelder, American Museum of Natural History; Dr. R. H. Baker, Michigan State University; Drs. W. H. Burt and E. T. Hooper, Museum of Zoology, University of Michigan; Dr. I. McTaggart Cowan, University of British Columbia; Dr. J. Dorst and Mme. H. Genest, Muséum National d'Histoire Naturelle, Paris; Dr. H. Felten, Natur-Museum und Forschungs-Institut Senckenberg; Mr. C. J. Guiguet, Provincial Museum of British Columbia; Drs. C. O. Handley and C. E. Ray, United States National Museum; Mr. J. E. Hill, the British Museum (Natural History); Dr. P. V. Jensen, Zoological Museum, Kopenhagen; Dr. J. Knox Jones, Museum of Natural History, University of Kansas; Dr. Barbara Lawrence, Museum of Comparative Zoology, Harvard University; Dr. J. M. Layne, Cornell University; Dr. W. Z. Lidicker, Museum of Vertebrate Zoology, University of California; Dr. X. Misonne, Institut Royal des Sciences de Belgique; Dr. J. C. Moore, Field Museum of Natural History, Chicago; Dr. M. Olson, Swedish Museum of Natural History, Stockholm; Dr. R. T. Orr, California Academy of Sciences; Dr. W. O. Pruitt, Memorial University; Dr. H. R. Roberts, Academy of Natural Sciences of Philadelphia; Dr. C. Sibley, Peabody Museum, Yale University; Mr. P. M. Youngman, National Museum of Canada.

I am grateful to Dr. J. H. Soper, formerly at the Botany Department, University of Toronto, and now at the National Museum of Natural Sciences and to Dr. D. W. Smith, Botany Department, University of Guelph, who provided computer programs; to Dr. D. M. Power, Department of Ornithology, Royal Ontario Museum (ROM), for the use of his programs, advice relating to data processing and for critically reviewing the manuscript; and to Dr. T. S. Parsons for his criticisms of the manuscript. Mrs. Sophie Poray prepared the illustrations of skulls and dentition, and the Institute of Computer Sciences at the University of Toronto provided computer time.

I thank in particular Dr. R. L. Peterson for his assistance and constructive criticism during the course of this study and the Royal Ontario Museum for providing facilities that enabled me to carry out the work. To Mrs. Eleanor Fenton, former librarian of the Royal Ontario Museum, and to the library staff, I express my gratitude for their unstinted co-operation in arranging interlibrary loans.

I gratefully acknowledge the financial support received from the Canadian National Sportsmen's Show through the office of Mr. F. H. Kortright, Chairman. 



\section{Literature Cited}

ALLEN, G. M.

1939 A checklist of African mammals. Bull. Mus. Comp. Zool. Harv.. no. 83, pp. 1-763.

ALLEN, J. A.

1908 Mammals from Nicaragua. Bull. Am. Mus. Nat. Hist., no. 24, pp. 647-670.

AMEGHINO, F.

1916 Obras completas y correspondancia científica. Vol. 6. Los mamíferos fósiles de la República Argentina. Part I. Planungulados y unguiculados. Edicíon oficial . . dirigida por Alfredo J. Torcelli.

La Plata, Taller de impresiones oficiales. $620 \mathrm{pp}$.

BAHRENS, D.

1960 Über den Formenwandel des Mustelidenschädels. Allometrische Untersuchungen an Schädeln von Mustela vison, Mustela lutreola, Mustela nivalis und Martes martes. Gegenbaurs Morph. Jb., band 101, pp. 279-369.

BARABASCH-NIKIFOROV, I. I.

1962 Der Seeotter oder Kalan (Enhydra lutris L.). Wittenberg Lutherstadt, A. Ziemsen Verlag. 92 pp.

BATE, D. M. A.

1935 Two new mammals from the Pleistocene of Malta, with notes on the associated fauna. Proc. Zool. Soc. Lond., no. 107, pp. 247-264. BOHLKEN, H.

1961 Allometrische Untersuchungen an den Schädeln asiatischer Wildrinder. Z. Säugetierk., band 26, pp. 147-154.

1964 Vergleichende Untersuchungen an den Schädeln wilder und domestizierter Rinder. Z. Wiss. Zool., band 170, pp. 323-418.

BURT, W. H.

1960 Bacula of North American mammals. Misc. Publ. Mus. Zool. Univ. Mich., no. 113, pp. 1-76.

CABRERA, A.

1924 Una nueva nutria de la América Central. Bol. R. Soc. Esp. Hist. Nat., no. 24, pp. 52-53.

1957 Catálogo de los mamíferos de América del Sur. Revta. Mus. Argent. Cienc. Nat. Bernardina Rivadavia (1958), tomo 4, no. 1, pp. $1-307$.

CHASEN, P. N.

1940 A handlist of Malaysian mammals. Bull. Raffles Mus., no. 15. pp. 1-209.

COOKE, H. B. S.

1963 African mammals in the fossil record. Proc. 16th Int. Congr. Zool., vol. 4, pp. 46-51.

1968 The fossil mammal fauna of Africa. Q. Rev. Biol., vol. 43, no. 3. pp. 234-264.

COPE, E. D.

1899 Vertebrate remains from the Port Kennedy bone deposit. J. Acad.

Nat. Sci. Philad., ser. 2, vol. 11. pp. 193-267. 
DARLINGTON, P. J. JR.

1957 Zoogeography; the geographical distribution of animals. New York, Wiley. 675 pp.

DIDIER, R.

1947 Étude systématique de l'os pénien des mammifères. Suite 2. Famille des Mustelidés. Mammalia, tome 11, pp. 139-152.

1948 Étude systématique de l'os pénien des mammifères. Mammalia, tome 12, pp. 67-93.

DYCK, J.

1966 Determination of plumage colours, feather pigments and structures by means of reflection spectrophotometry. Dansk Orn. Foren. Tidsskr., vol. 60, no. 2, pp. 49-76.

ELLERMAN, J. R. AND T. C. S. MORRISON-SCOTT

1951 Checklist of Palaearctic and Indian mammals 1758-1946. London. British Museum (Natural History). 810 pp.

FAHLBUSCH, V.

1967 Über einen Potamotherium - Kiefer (Carnivora, Mamm.) aus dem Obermiocän von Reichenstetten bei Regensburg. Mitt. Bayer. Staatssamml. Paläont. Hist. Geol., band 7, pp. 193-200.

FRILEY, C. E. JR.

1949 Age determination, by use of the baculum, in the river otter Lutra c. canadensis Schreber. J. Mammal., vol. 30, pp. 102-110.

FURLONG, E. L.

1932 A new genus of otter from the Pliocene of the northern Great Basin Province. Contr. Palaeont., no. 418, pp. 93-103.

GIDLEY, J. W. AND C. L. GAZIN

1938 The Pleistocene vertebrate fauna from Cumberland Cave, Maryland. Bull. U.S. Natn. Mus., no. 171, pp. 1-99. GOLDMAN, E. A.

1941 A Pleistocene otter from Iowa. Fieldiana Zool., vol. 27, pp. 229-231.

GOODWIN, G. G.

1946 Mammals of Costa Rica. Bull. Am. Mus. Nat. Hist., vol. 87, art. 5, pp. 275-473.

GOULD, S. J.

1966 Allometry and size in ontogeny and phylogeny. Biol. Rev., vol. 41, pp. 587-640.

GRAY, J. E.

1865 Revision of the genera and species of Mustelidae contained in the British Museum. Proc. Zool. Soc. Lond., pp. 100-154.

HALL, E. R.

1936 Mustelid mammals from the Pleistocene of North America, with systematic notes on some recent members of the genera Mustela, Taxidea and Mephitis. Contr. Paleontol., no. 473, pp. 41-119.

HALL, E. R. AND K. R. KELSON

1959 The mammals of North America. New York, Ronald Press. 2 vols. HARDY, A. C.

1936 Handbook of Colorimetry. M.I.T.

HARRIS, C. J.

1968 Otters: a study of the Recent Lutrinae. London, Weidenfeld and Nicolson. 397 pp. 
HELBING, H.

1935 Cyrnaonyx antiqua (Blainv.) ein Lutrine aus dem europäischen Pleistozän. Eclog. Geol. Helv., band 28, pp. 563-577.

1936 Die Carnivoren des Steinheimer Beckens. A. Mustelidae. Palaeontographica, Suppl., band 8, pp. 1-56.

HERSHKOVITZ, P.

1959 Nomenclature and taxonomy of the Neotropical mammals described by Olfers, 1818. J. Mammal., vol. 40, pp. 337-353.

1966 Mice, land bridges and Latin American faunal interchange. In Wenzel, R. L. and V. J. Tipton, eds. Ectoparasites of Panama. Chicago, Field Museum of Natural History, pp. 725-751.

HIBBARD, C. W.

1958 Summary of North American Pleistocene mammalian local faunas. Pap. Mich. Acad. Sci., no. 43, pp. 3-32.

HOERSCHELMANN, H. VON

1966 Allometrische Untersuchungen am Rumpf und Flügel von Schnepfenvögeln (Charadriidae und Scolopacidae). Z. Zool. Syst. Evolut.Forsch., band 4, pp. 209-317.

HOOPER, E. T. AND B. T. OSTENSON

1949 Age groups in Michigan otter. Occ. Pap. Mus. Zool. Univ. Mich., no. 518, pp. 1-22.

HOPKINS, D. M.

1967 The Bering Land Bridge. Stanford, Calif., Stanford University Press. 495 pp.

HOPWOOD, A. T., AND J. P. HOLLYFIELD

1954 An annotated bibliography of the fossil mammals of Africa (17421950). Fossil Mammals of Africa, no. 8. London, British Museum (Natural History). 194 pp.

HYSING-DAHL, CHR.

1959 The Norwegian otter Lutra lutra (L.), a craniometric investigation. Univ. Bergen Arb., Naturvitenskapelig rekke 5, pp. 1-44.

KRETZOI, M.

1951 The Hipparion-fauna from Csakvar. Foldt. Kozl., no. 81, pp. 384-417.

KURTÉN, B.

1964 The evolution of the polar bear, Ursus maritimus Phipps. Acta Zool. Fenn., no. 108, pp. 3-30.

1968 Pleistocene mammals of Europe. London, Weidenfeld and Nicolson. 317 pp.

KURTÉN, B., AND R. RAUSCH

1959 Biometric comparisons between North American and European mammals. Acta Arct., fasc. 11, pp. 1-45.

LEFFLER, S. R.

1964 Fossil mammals from the Elk River formation, Cape Blanco, Oregon. J. Mammal., vol. 45. pp. 53-61.

MACDONALD, J. R.

1956 A new Clarendonian mammalian fauna from the Truckee formation of western Nevada. J. Paleont., vol. 30, no. 1, pp. 186-202.

MAYR, E.

1942 Systematics and the origin of species from the viewpoint of a zoologist. New York, Columbia University Press. 334 pp. 
MAYR, E.

1963 Animal species and evolution. Cambridge, Belknap Piess of Harvard University. $797 \mathrm{pp}$.

MAYR, E., E. G. LINSLEY AND R. L. USINGER

1953 Methods and principles of systematic zoology. New York. McGraw-Hill. 328 pp.

MILLER, G. S., AND R. KELLOGG

1955 List of North American recent mammals. Bul!. U.S. Natn. Mus., no. 205, pp. 1-954.

MITCHELL, E.

1966 Northeastern Pacific Pleistocene sea otters. J. Fish. Res. Bd. Can., vol. 23 , no. 12, pp. 1897-1911.

NOVIKOV, G. A.

1962 Carnivorous mammals of the fauna of the U.S.S.R. Translated from Russian. Jerusalem, Israel Program for Scientific Translations. $283 \mathrm{pp}$.

OGNEV, S. I.

1962 Mammals of eastern Europe and northern Asia. Vol. 3. Carnivora (Fissipedia + Pinnipedia). Translated from Russian. Jerusalem. Israel Program for Scientific Translations. $641 \mathrm{pp}$.

PEI, W. C.

1934 On the Carnivora from locality 1 of Choukoutien. Palaeont. Sin., ser. C, vol. 8, fasc. 1, pp. 1-216.

PILGRIM, G. E.

1932 The fossil Carnivora of India. Mem. Geol. Surv. India, Palaeont. Indica, n.s., vol. 18, pp. 1-232.

PIVETEAU, J.

1961 Traité de Paléontologie. Vol. 6. L’origine des mammifères et les aspects fondamentaux de leur évolution en deux vols., Pt. 1. Mammifères, origine reptilienne, évolution. Paris, Masson et Cie. $1135 \mathrm{pp}$.

POCOCK, R. I.

1921 On the external characters of some species of Lutrinae (otters). Proc. Zool. Soc. Lond., pt. 3, pp. 535-546.

1940 Notes on some British Indian otters, with descriptions of two new subspecies. J. Bombay Nat. Hist. Soc., vol. 41, pp. 514-517.

POHLE, H.

1920 Dic Unterfamilie der Lutrinae. (Eine systematisch-tiergeographische Studie an dem Material der Berliner Museen). Arch. Naturgesch. Jahrg. 85, 1919, abt. A, heft 9, pp. 1-247.

RHOADS, S. N.

1898 Contributions to a revision of the North American beavers, otters and fishers. Trans. Am. Phil. Soc., n.s., vol. 19, pp. 417-439. ROMAN, F., AND F. VIRET

1934 La faune de mammifères du Burdigalien de la Romieu (Gers). Mém. Soc. Géol. Fr., n.s., no. 21, pp. 1-67.

RUTTLE, T.

1968 How to grade furs. Canada Dep. Agriculture Publ. 1362, pp. 1-91. SAVAGE, R. J. G.

1957 The anatomy of Potamotherium, an Oligocene lutrine. Proc. Zool. Soc. Lond., vol. 129, pt. 2, pp. 151-244.

SIMPSON, G. G.

1945 The principles of classification and a classification of mammals. Bull. Am. Mus. Nat. Hist., vol. 85, pp. 1-350. 
SIMPSON, G. G.

1950 History of the fauna of Latin America. Am. Scient., vol. 38, no. 3, pp. 361-389.

1961 Principles of animal taxonomy. New York, Columbia University Press. 247 pp.

SIMPSON, G. G., A. ROE AND R. C. LEWONTIN

1960 Quantitative zoology. Rev. ed. New York, Harcourt, Brace. $440 \mathrm{pp}$.

SOKAL, R. R.

1965 Statistical methods in systematics. Biol. Rev., vol. 40, no. 3, pp. 337-391.

1966 Numerical taxonomy. Scient. Am., vol. 215, no. 6, pp. 106-116.

SOKAL, R. R., AND P. H. A. SNEATH

1963 Principles of numerical taxonomy. San Francisco, W. H. Freeman. $359 \mathrm{pp}$.

TEILHARD DE CHARDIN, P., AND P. LEROY

1945 Les mustelidés de Chine. Publ. Inst. Géobiol. Pékin, no. 12, pp. $1-56$.

TEILHARD DE CHARDIN, P., AND J. PIVETEAU

1930 Les Mammifères fossiles de Nihowan (Chine). Annls. Paléont., tome 19 , pp. 3-134.

THENIUS, E.

1949 Die Lutrinen des steirischen Tertiärs (Beitrage zur Kenntnis der Säugetierreste des steirischen Tertiärs I.). Sber. Ost. Akad. Wiss., band 158, pp. 299-322.

1965 Die Carnivoren-Reste aus dem Altpleistozän von Voigtstedt bei Sangerhausen in Thüringen. Paläont. Abh., ser. A., 2, pp. 537-562.

1967 Zur Phylogenie der Feliden (Carnivora, Mamm.). Z. Zool. Syst. Evolut.-Forsch., band 5. heft 2, pp. 129-143.

THOMAS, 0 .

1908 On certain African and South American otters. Ann. Mag. Nat. Hist., ser. 8, vol. 1, pp. 387-395.

1914 New Nasua, Lutra and Proechimys from South America. Ann. Mag. Nat. Hist., ser. 8, vol. 14, pp. 57-61.

1920 Report on the mammalia collected by Mr. Edmund Heller during the Peruvian expedition of 1915 under the auspices of Yale University and the National Geographic Society. Proc. U.S. Natn. Mus., vol. 58. pp. 217-249.

VAN BREE, P. J. H.

1968 Einige Bemerkungen über den Glattotter, Lutrogale perspicillata (Is. Geoffroy, 1826) (Carnivora, Lutrinae), aus dem Indo-Australishchen Archipel. Zool. Gart., band 35, pp. 30-36.

VAN ZYLL DE JONG, C. G.

1968 A systematic study of the Nearctic and Neotropical river otters. (Order: Carnivora; Family: Mustelidae). Ph.D. thesis, University of Toronto. $161 \mathrm{pp}$.

VILLALTA COMELLA, J. F. DE

1952 Contribución al conocimiento de la fauna de mamíferos fósiles del Plioceno de Villarroya (Logrono). Boln. Inst. Geol. Min. Esp., no. 64, pp. 1-201.

VIRET, J.

1954 Le Loess a bancs durcis de Saint-Vallier (Drome), et sa taune de mammifères villafranchiens. Nouv. Archs. Mus. Hist. Nat. Lyon, fasc. 4, pp. 1-200. 
WILSON, E. O., AND W. L. BROWN

1953 The subspecies concept and its taxonomic application. Syst. Zool., vol. 2, no. 3, pp. 97-111.

ZDANSKY, $\mathrm{O}$.

1924 Jungtertiäre Carnivoren Chinas. Paleont. Sin., ser. C. vol. 2, fasc. 1, pp. 1-149. 


\section{Appendix 1 - Specimens Examined}

\section{Genus Lontra Gray}

\section{Lontra canadensis canadensis (Schreber)}

Connecticut (3): Portland, 2 (USNM); Liberty Hill, 1 (MCZ). Labrador (23): Ashuamibi Lake (Ashuanipi L. ?), 1 (USNM); Grand River, 1 (ANSP), Hopedale, 4 (MCZ); Island Harbor, 2 ( MCZ); Kippokak Bay, 4 (MCZ); L'Anse au Loup, 5 (MCZ); Makkovik, 3 (MCZ); Ft. Nascopie (Naskaupi ?), 1 (USNM); Paradise, 1 (USNM); Paradise River ( 35 mi. above mouth), 1 (USNM). Maine (22): Aroostook Co., Big Fish River, 1 (MCZ); Bucksport, 1 (MCZ); Moosehead Lake, 4 (MCZ); Piscataquis Co., 5 ( $\mathrm{MCZ}$ ); Umbagog Lake, 1 (MCZ); Upton, 2 (MCZ); no specific locality, 1 (USNM), 7 (UM). Massachusetts (4): Canton, Neponset River, 1 (MCZ); Sudbury, 1 (MCZ); Swampscott, 1 (MCZ); Westford, 1 (MCZ). Michigan (26): Alcona Co., Harrisonville, 1 (UM); Alger Co., 1 (UM); Alpena 2 (UM); Cheboygan Co., 1 (UM); Crawford Co., 2 (UM); Gladwin Co., 1 (UM); Gogebic Co., 1 (UM); Houghton Co., 1 (UM); Iron Co., 1 (UM); Marquette Co., 1 (UM); Michigan Co., 1 (UM); Missaukee Co., 1 (UM); Montmorency, 4 (UM); Oscoda Co., 1 (UM); Otsego Co., 1 (UM); Schoolcraft Co., 1 (UM); no specific locality, 5 (UM). New Brunswick (1): no specific locality, 1 (USNM). Newfoundland (18): Avalon Peninsula, 1 (Mемu); Bay St. George, 3 ( MCZ); Carberry, 1 ( вом); Gander River, 1 (NMC); Humber River, 1 (AMNH); no specific locality, 9 (MCZ); 2 (ROM). New Hampshire (1): West Moreland, 1 (MCZ). New York (19): Franklin Co., 10 (cu); Essex Co., 1 (cu); Hamilton Co., 2 (cu); Herkimer Co., 1 (CU); Lewis Co., 2 (cu); St. Lawrence Co., 1 (cu); Warren Co., 1 (cu); no specific locality, 1 (CU). Nova Scotia (4): Annapolis, 1 (MCZ); Kings Co., 1 (NMC); Halifax (4 mi. south), 1 (USNM); Moose River, 1 (ROM). Ontario (47): Algoma Dist., Amyot, 1 ( вом); Laird Twp., 1 (вом); Puskuta Twp., 2 (вом); Walls Twp., 1 (вом); Whitman Twp., 1 (вом); Algonquin Park, Lake Opeongo, 1 (вом); Cockburn Island, 1 (вом); Cochrane Dist., Lake Abitibi, 2 (RоM); Smoky Falls, 2 (RоM); Emsdale, 1 (NMC); Kamiskotia Lake, 1 (NMC); Kenora Dist., Cedar Lake, 2 (Rом); Fi. Severn, 4 (Rом); Lanark Co., Dalhousie Lake, 1 (NMC); Muskoka Dist., Port Sidney, 1 (Rом); Nipissing Dist., Airy Twp., 1 ( Sound, Humphrey Twp., 1 (вом); Sudbury Dist., Athlone Twp., 2 (вом); Bader Twp., 1 (Rом); Blamey Twp., 1 (Rом); Chapleau Twp., 1 (Rом); Halsey Twp., 4 (Rом); LaFleche Twp.. 1 (Rом); Reeves Twp., 1 (вом); Smuts Twp., 1 (Rом); Twp. 10E, 1 (Rом); Twp. 21 (Hoey Twp.), 1 (Rом); Twp. 23, 1 (Rом); Thunder Bay Dist., Bowman Island, 1 (RоM); Hope Island, 1 (вом); Sturgeon Lake, 1 (ROM); Willard Island, 1 (ROM); Tyconderoga Twp. (Tyendinaga ?), 1, (NMC); no specific locality, 2 (RоM). Quebec (25): Cascapedia River, 4 (NMC); East Main River, 2 (ANSP), 1 (AMNH); Ft. George River, 1 (ANSP); Godbout, 2 (USNM); Lake Edward, 1 (NMC); Lake St. John 1 (USNM); Laurentides (N. W. of), 1 (NMC); Mistassini, 6 (NMC); Ungava Bay, Ft. Chimo, 5 (NMC), 1 (USNM). Total -193.

\section{Lontra canadensis lataxina (G. F. Cuvier)}

Alabama (1): Mobile River, 1 (USNM). Connecticut (2): Killingworth, 1 (YPM); North Madison, 1 (YPM). Florida (24): Caloosa, Lee Co.. 1 (ANSP); Clearmont Lake Co., 1 (MSU); Flamingo, 1 (USNM); Ft. Kissimmec, 2 (USNM); 
Ft. Lauderdale, 1 (USNM); Everglades, 1 (USNM), 1 (ROM); Kissimmee, Aligator Bluff, 1 (USNM); Kissimmee ( 35 mi. S.), 1 (ANSP); Monroe Co., 3 (UM), New Smyrna, 1 (USNM); Tarpon Springs, 1 (USNM); 2 (ANSP); West Palm Beach, 1 (USNM); no specific locality, 5 (USNM), 1 (YPM). Georgia (13): Fargo, 1 (USNM); Okefenokee, 3 (USNM), 2 (ANSP); Pretoria, 2 (USNM); St. Simon's Island, 2 (USNM); Sapelo Island, 1 (USNM); Talbot Co., 1 (USNM), Vienna, Flint River, 1 (USNM). Indiana (1): Patoka Creek, Gibson Co., 1 (USNM). Iowa (1): No specific locality, 1 (MCZ). Kansas (3): Council Grove, 1 (USNM); Manhattan, 1 (USNM); Parks Fort, 1 (YPM). Louisiana (14): Belle Isle, 2 (USNM); Cameron, 1 (USNM); Chenière au Tigre, 2 (USNM); Lacassine Bayou, 1 (USNM); Sabine refuge, 4 (USNM); Tallulah, 2 (USNM); Southwestern Louisiana, 2 (MVZ). Maryland (1): Glen Echo, 1 (USNM). Missouri (1): No specific locality, 1 (ANSP). Nebraska (3): Halle River, 1 (USNM); Ft. Kearney, 1 (USNM); no specific locality, 1 (YPM). New Jersey (3): Auburn, Salem Co., 1 (ANSP); Mickleton, 1 (ANSP); Tuckerton, 1 (ANSP). North Carolina (3): Fort Caswell, 1 (USNM); Raleigh, 2 (MCZ). Oklahoma (2): Ft. Cobbe, 1 (USNM); Woodward Co., 1 (KU). Pennsylvania (3): Bushkill Creek, Monroe Co., 2 (ANSP); Bushkill Creek, S.W. Pike Co., 1 (ansP). South Carolina (1): Mount Pleasant, 1 (USNM). Texas (4): Angleton, 2 (USNM); Bay City, 1 (USNM); Brownsville, 1 (ANSP). Virginia (5): Barksdale Dept., 1 (USNM); King George County, 1 (USNM); Richmond Co., 1 (USNM); Virginia Beach, 1 (MCZ); no specific locality, 1 (USNM). Washington (D.C.) (3): 3 (USNM). Total -88

\section{Lontra canadensis pacifica (Rhoads)}

Alaska (34): Becharof Lake (between Becharof L. and Portage Bay), 3 (USNM); Becharof Lake, 1 (USNM); Cape Elizabeth, 9 (USNM); Hinchinbrook Island, 1 (USNM); Kenai Pen., 2 (USNM), 1 (FMNH), 2 (MVZ); Kuskokwim River, 2 (USNM); Lake Louise near Glenn Highway at mile 167, 1 (MCZ); Mission, 1 (USNM); Montague Island, 2 (USNM), 2 (MVZ); Nagai Island, 1 (USNM); Ruby on the Yukon, 1 (USNM); Snug Harbor, 1 (MVZ); Sunshine Point, Kaliakh River, Yakataga, 1 (CAS); Tanana River, 1 (USNM); Unalakleet, 1 (USNM); no specific locality, 1 (CAS). Alberta (7): Henry House, 1 (USNM); Jasper, 2 (NMC); Slave River (10 mi. below Peace River), 1 (USNM); Whitemud, I (USNM); Wood Buffalo Park, Conibear Lake, 1 (NMC) and Little Buffalo River, 1 (NMC). British Columbia (55): Ahbau Lake, Barkerville Dist., 1 ( Mvz); Anahim Lake, 1 ( mvz); Avola, N. Thompson River, 1 (UBC); Barkerville, Indianpoint Creek, 1 (MVZ); Bear Lake, 1 ( $\mathrm{PMBC}$ ); Ben Lake, Cariboo Dist., 1 (UBC); Driftwood Lake, 2 (PMBC); Eight Mile Creek, Cherryville, Osoyoos Dist., 1 (Rом); Fraser Valley, $40 \mathrm{mi}$. W. of Hope, 1 (UBC); Horsefly, 5 (NMC); Kechika River, 1 (UBC); Meldrum Creek, Quesnel (?), 1 (UBC); Kettle Valley, 1 (UBC); Newton Creek, Chezacut, 1 (UBC); N. Fork, Eagle River, 1 (UBC); Stuart Lake, 34 (USNM); Vernon, 1 (ANSP). California (24): Carlotta, Humboldt Co., 3 (Mvz); Cuddeback, Humboldt Co., 4 (MvZ); Price Creek, Humboldt Co., 1 (mvz); Pit River, 4 (USNm); Round Mt., 1 (USNm); Shasta Co., 1 (USNM); Solano Co., Grizzly Island, 4 (MVZ); Joyce Island, Solano Co., 5 (MVZ); no specific locality, 1 (CAS). Idaho (7): Birch Creek, 1 (USNM); Bruneau, 1 (USNM); Coeur d'Alene, 2 (USNM); Hagerman, 1 (USNM); Sawtooth, 1 (USNM); Teton River, 1 (USNM). Manitoba (44): Aimee Lake, Flin Flon, 1 (NMC); Bird (H. B. railway, mile 349), 1 (NMC); Cross Lake, 1 (USNM); Herb Lake, 9 (UBC); 
Norway House, 5 (USNM); Oxford House, 20 (USNM), 6 (UBC); Pikwetonei, 1 (UBC). Minnesota (4): Elk River, 3 (USNM); Wabasha Co., 1 (USNM). Montana (1): Yellowstone River, near Gardiner, 1 ( MvZ). Nevada (7): Elko, Elko Co., 1 (UM); Deeth, Elko Co., 1 (USNM); 1 (MVZ); Galconda, 2 (USNM), 1 (MVZ); Faradise, 1 (USNM). Northwest Territories (4): District of Mackenzie, Ft. Liard, 1 (USNM); Ft. Smith, 1 (USNM); McTavish Bay, Great Bear Lake, 1 (USNM); South Nahanni River, 1 (NMC). Oregon (5): Glendale, 1 (USNM); John Day River, 1 (YPM); near Rome, Owyhee River, 1 (USNM); Smith River near Gardiner, 1 (USNM); Tillamook Co., Manhattan, 1 (UM). Washington (25): Clallam Co., 8 mi. W. of Forks, 1 (USNM); Forks, Clallam Co., 9 (USNM), 1 ( РмвC); Sappho, Clallam Co., 1 ( РмвC); Clearwater River, 1 (USNM); Columbia River, 1 (YPM); Humptulips R., 1 (USNM); Lake Quinalt, 1 (USNM); Monse, Okanogan Co., 1 (USNM); Mt. Vernon, 1 (USNM); Palmer Lake, Okanogan Co., 1 (USNM); Tacoma, 2 (ANSP); Trout Lake, Mt. Adam, 3 (USNM); Wahkiakum Co., Puget Island, Columbia River, 1 (USNM). Wyoming (1): Upper Yellowstone River, 1 (USNM). Yukon (7): Hungry Lake, 2 (NMC); Lake Teslin. Beaver Creek, 1 (NMC); Pelly River, 1 (USNM); Stewart River (20 mi. n. of mouth), 1 (NMC); Thistle Creek ( $8 \mathrm{mi}$. above mouth of White River), 1 (NMC); Whitehorse ( $63 / 4$ mi. S.W. of ), 1 (NMC). Total -225

\section{Lontra canadensis mira (Goldman)}

Alaska (12): Anklin River, Yakutat, 1 (MVZ); Howkan, near Dall Island, 3 (MVZ); Marble Island, W. of Prince of Wales Island, 1 (USNM); Prince of Wales Island, 4 (USNM); Shrubby Island, 1 (USNM); Taku, 1 (USNM); Windfall Harbor, 1 (Mvz). British Columbia (11): Anvil Island, Howe Sound, 1 (UBC); Bella Bella, 2 ( $\mathrm{PMBC}$ ); Bella Coola, 2 ( PMBC), 2 (NMC); Eden Island. 1 ( $\mathrm{PMBC}$ ); Lulu Island, 1 (UBC); Stikene River, 1 ( $\mathrm{MCZ}$ ); Sumas, 1 ( $\mathrm{MCZ}$ ). Vancouver Island (17): Alberni, 4 ( $\mathrm{PMBC}$ ); Bamfield, 2 ( $\mathrm{PMBC)}$ ) Parksville, 1 (MVZ); Port Hardy, 1 (UBC); Quatsino Sound, 2 (PMBC), 2 (USNM); Sooke, 3 ( $\mathrm{PMBC}$ ); no specific locality, 1 (UBC), 1 (USNM). Total -40

\section{Lontra canadensis periclyzomae (Elliot)}

Queen Charlotte Islands (22): Copper Bay, 1 (UBC); George Bay, 1 (UBC); Graham Island, 7 (USNM); Henslung Bay, Langara Island, 1 (UBC); Lepas Bay, Graham Island, 1 (UBC); Pacofi, 1 (UBC); Peril Bay, Graham Island, 1 (UBC) ; Sangan River, 2 (UBC); Skedans Bay, Louise Island, 1 (UBC); no specific locality, 3 (FMNH), 2 ( MVZ), 1 (USNM). Total -22

\section{Lontra canadensis kodiacensis (Goldman)}

Alaska (17): Afognak Island, 1 (USNM); Kodiak Island, 13 (USNM): Shuyak Island, 3 (UM). Total -17

\section{Lontra canadensis sonora (Rhoads)}

Arizona (1): Beaver Creck, Yavapai Co., 1 (AMNH). California (1): Colorado River, 8 mi. above Needles, San Bernardino Co., I ( MVz). New Mexico (1) : Cliff, Grant Co., Gila River, 1 (USNM). Total - 3 


\section{Lontra longicaudis longicaudis (Olfers)}

Argentina (1): Lower regions of Paraná River, 1 (SMNh). Brazil (13): Anápolis, Goiás, 2 (AMNH); Cayua, 1 (USNM); Chapada, Matto Grosso, 2 (ANSP); Descalvados, Matto Grosso, 1 (FMNH); Santa Rita, 1 ( $\mathrm{MCZ}$ ); São João do Monte Negro, Rio Grande do Sul, 1 (ANSP); no specific locality, 2 (ZM); 3 (smnh). Paraguay (3): Yguazu and Yuqueri Rivers, 3 (MCZ). Uruguay (2): Dept. Lavalleja, $12 \mathrm{~km}$ W.S.W. of Zapicán, 1 (AMNH); no specific locality, 1 (AMNH). Total - 19

\section{Lontra longicaudis enudris (G. F. Cuvier)}

Bolivia (4): Depto. Beni, Río Itenez, 2 (AMNh); San Fermin, 1 (smNh); Santa Cruz, nr. Buenavista, Santa Cruz Dist., 1 (Fmnh). Brazil (3): Pôrto Real, Prov. Rio de Janeiro, 2 ( вм); no specific locality, 1 ( амNH). Colombia (5): Guaicaramo, 2 (AMNH); Macarena Mtns., 2 (AMNH); Villavicencio, 1 (AMNh). Ecuador (2): Río Jatún, Oriente, 1 ( MCZ); Río Suma, Oriente, 1 (FMNH). Guyana (8): Bonasica, 1 (вм); Georgetown, 1 (FMNH); Kalacoon, 1 (AMNH); Kartabo (Kartabu ?), 1 (AMNH); Kwitaro River, 1 (ROM); Providence, 1 (вм); Rio Supinaam, 1 ( вм); no specific locality, 1 ( амNH). Peru (4): Chanchamayo, 1 (USNM); Río Comberciato, 1 (USNM); Monte Alegre, Pachitea, 1 (AMNH); Río Nevati east of Pachitea, 1 (AMNH). Surinam (1): Maroni River, 1 ( в M). Total - 27

\section{Lontra longicaudis annectens (Major)}

British Honduras (1): Rockstone Pond, I (ROM). Colombia (4): Bonda, Santa Marta Distr., 3 (AMNH); Sta. Marta Mountains, 1 (MCZ). Costa Rica (4): Río Grande, Villa Colon, 1 (FMNH); Talamanca, 1 (USNM); no specific locality, 1 (MCZ), 1 (USNM). Ecuador (6): Gualea, 2 (SMNH); Mindo, Pichincha Prov., 1 (FMNH); Río Blanco, Mindo, 1 ( MNHN); Río Quimindes (Quininde ?), 1 (FMNH); Santa Rosa, 1 (UM). Honduras (3): Brewers Lagoon, 1 (CAS); Comayagua, 2 (MCZ). Mexico (12): Tuxtla Gutiérrez, Chiapas, 1 (UBC); Jalapa 1 (MCZ); Guadalajara, Jalisco, 1 (AMNH); Laguna, Juanacatlán (16 mi. S.E. of Guadalajara); Santa Efigenia, Tehuantepec, 2 (USNM); Santo Domingo, Oaxaca, 2 (USNM); Vera Cruz (near Jesús Carranza), 2 (KU); no specific locality, 3 ( MNHN). Nicaragua (3): Río Tuma, Matagalpa, 2 ( AMnh); Savala, Matagalpa, 1 (AMNh). Panama (7): Cana, 1 (USNM); Chimán, 1 (USNM); Chiriqui Biquete, 1 (USNM); Gatun, 1 (USNM); Tapalisa, 1 (amnh); no definite locality, 1 ( Mvz), 1 (mnhn). Perl (1): Eten, 1 (вм). Venezuela (1): Mérida, 1 (sMNH). Total -42

\section{Lontra provocax (Thomas)}

Argentina (2): Río Chubut, Chubut, 1 (Mvz); Patagonia, near mouth of Río Negro, 1 (USNM). Chile (5): Chiloé Island, Río Inio, 2 (FMNH); Maquehue, Temuco, 1 ( AMNH); Smythe's Channel, W. of Str. of Magellan, 1 (вM); no specific locality, 1 (NMFIS). Total -7

\section{Lontra felina (Molina)}

Chile (13): Atacamá, Caldera, 2 (FMNH); Ayentema, Chiloé Island, 1 (FMNH); Cucao, Chiloé Island, 2 (FMNH); Guitecas, Manaza Id., 3 (FMNH); Port Otway, 1 (USNM); Quiriquina Islands, 1 (ANSP); no specific locality, 2 (ZM), 1 (IRSB). Peru (1): Asia Island, Independencia Bay, 1 (AMNH). Total $-14$ 


\section{Appendix 2}

\section{Characters Used to Calculate Taxonomic Distance}

1. Interorbital width/basal length

2. Width postorb. proc./basal length

3. Orbito-nasal $1 . /$ basal length

4. Postorb. constr./basal length

5. Rostral w./basal length

6. Basal skull w./basal length

7. W. braincase/basal length

8. Mastoid w./basal length

9. Zygomatic w./ basal length

10. Palatal $1 . /$ basal length

11. Height occiput/basal length

12. L. mandible/basal length

13. L. upper P-M series/basal length

14. L. lower P-M series/basal length

15. Height cranium/basal length

16. Height bulla/basal length

17. Length bulla/basal length

18. Length $M_{1}$ /basal length

19. Length $\mathrm{P}^{4} /$ basal length

20. Interorb. w./ postorb. constr.

21. Interorb. w./w. postorb. proc.

22. Orbito-nasal 1./w. postorb. proc.

23. Rostral w./ palatal 1.

24. L. mandible/basal skull w.

25. Height cranium/basal skull w.

26. Height cranium/w. braincase
27. Height bulla/l. bulla

28. L. $\mathrm{M}_{1} /$ lower P-M series

29. L. $\mathrm{P}^{4} / 1$. upper $\mathrm{P}-\mathrm{M}$ series

30. W. $\mathrm{P}^{3} / 1 . \mathrm{P}^{3}$

31. W. $\mathrm{P}^{4} /$ buccal 1. $\mathrm{P}^{4}$

32. Talon 1. $\mathrm{P}^{4} /$ buccal 1. $\mathrm{P}^{4}$

33. Greatest diameter $\mathrm{M}^{1 /}$ basal length

34. Lingual $1 . \mathrm{M}^{1} /$ greatest diameter $\mathrm{M}^{1}$

35. Buccal 1. $\mathrm{M}^{1 / \text { greatest diameter }}$ $\mathrm{M}^{1}$

36. W. $M_{1} / 1 . M_{1}$

37. L. $\mathrm{M}_{2} / \mathrm{w} \cdot \mathrm{M}_{2}$

38. Buccal 1. $\mathrm{P}^{4 /} /$ greatest diameter $\mathrm{M}^{1}$

39. Ramus height/l. mandible

40. Upper P-M series/1. palate

41. Dental formula

42. Number of mammae

43. Amount of webbing, front foot

44. Amount of webbing, hind foot

45. Claw development

46. Number of thoracic vertebrae

47. Number of sacral vertebrae

48. Number of caudal vertebrae

\section{Appendix 3}

Selected skull and tooth measurements (by original taxa) of forms now referred to Lontra. Sample size $(\mathrm{N})$, mean $(\overline{\mathrm{X}})$ and standard deviation $(\mathrm{S})$ are given, and samples were grouped according to results of the analysis of overall similarity. See pages 102, 103, and 104. 


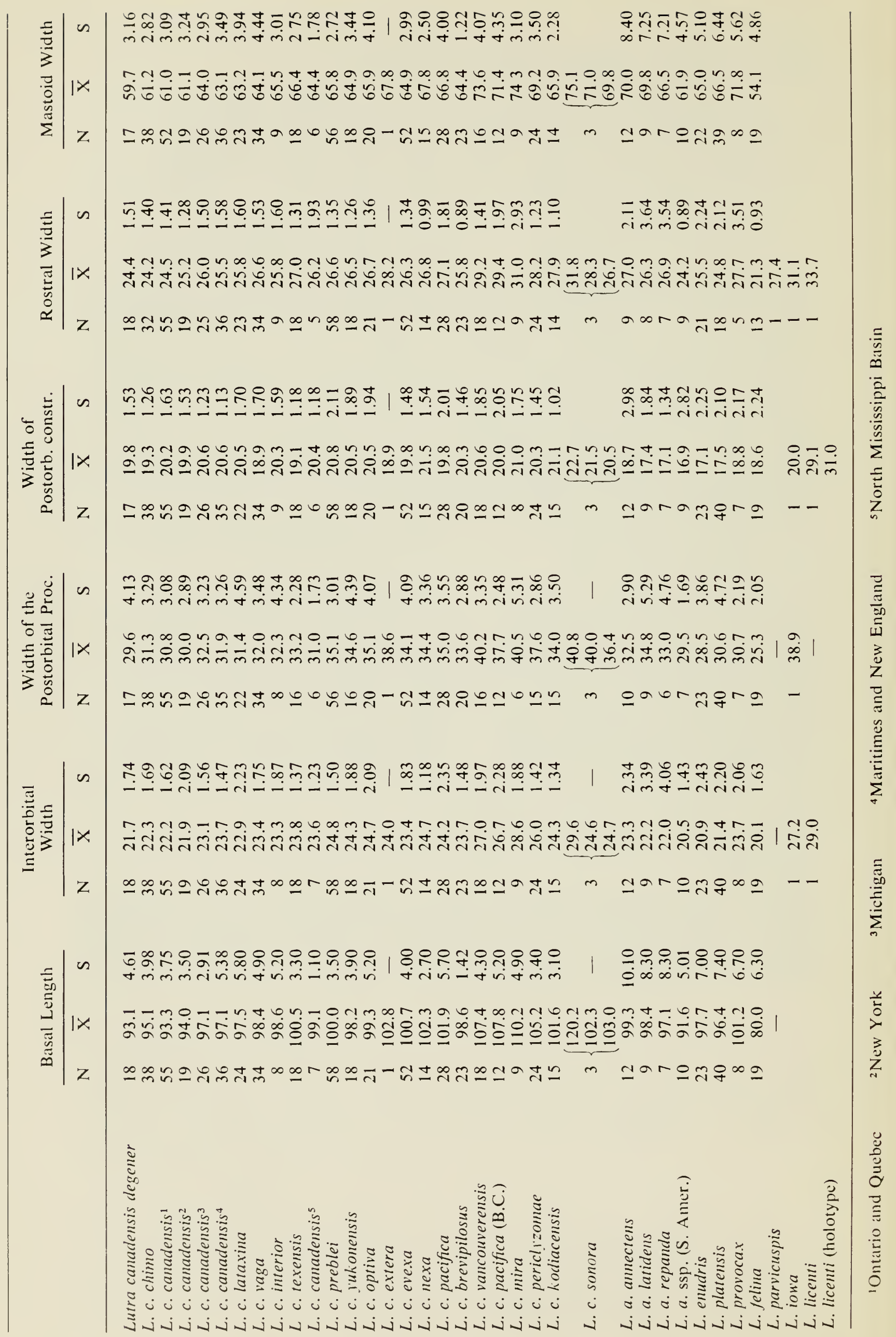




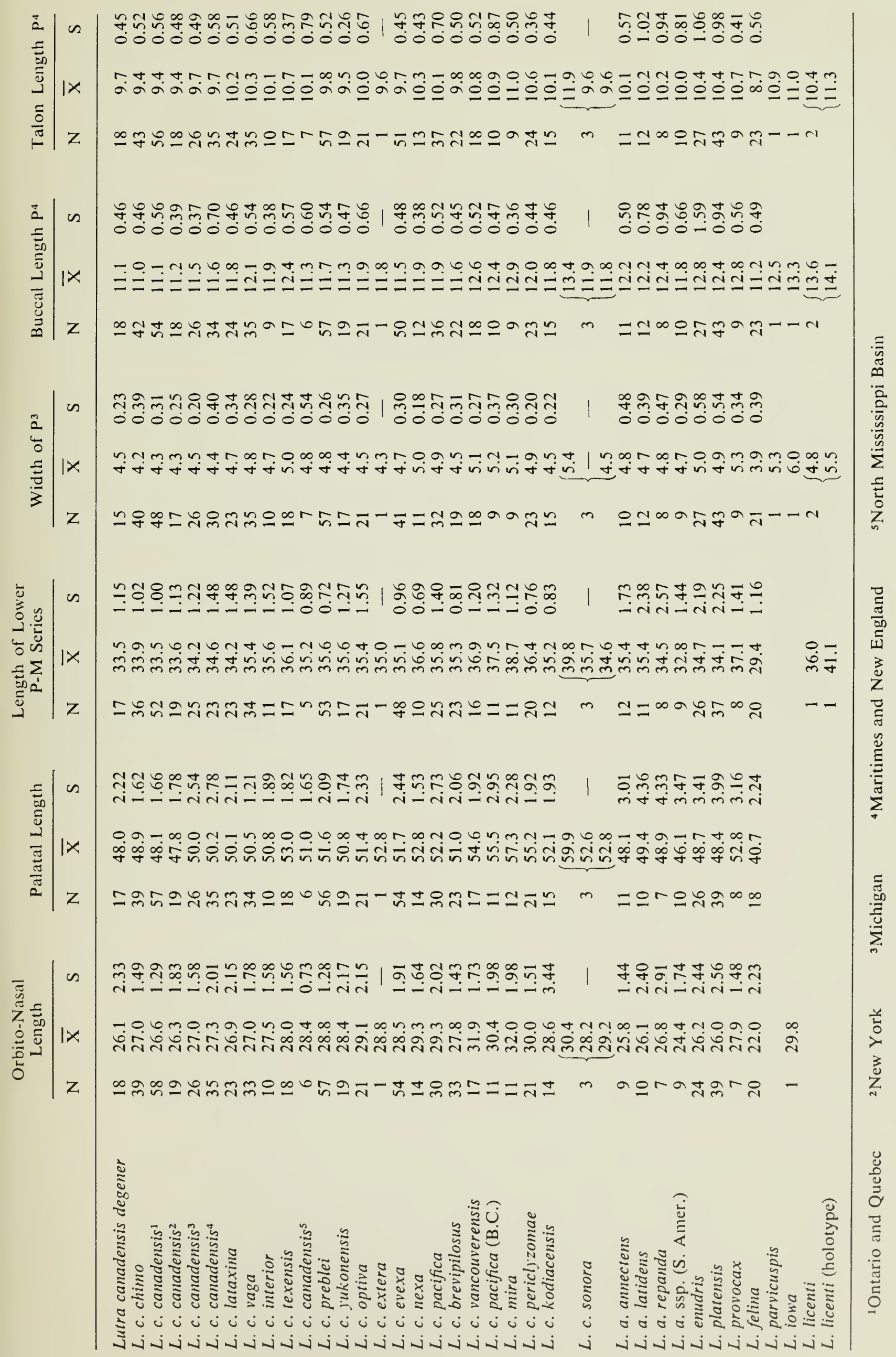




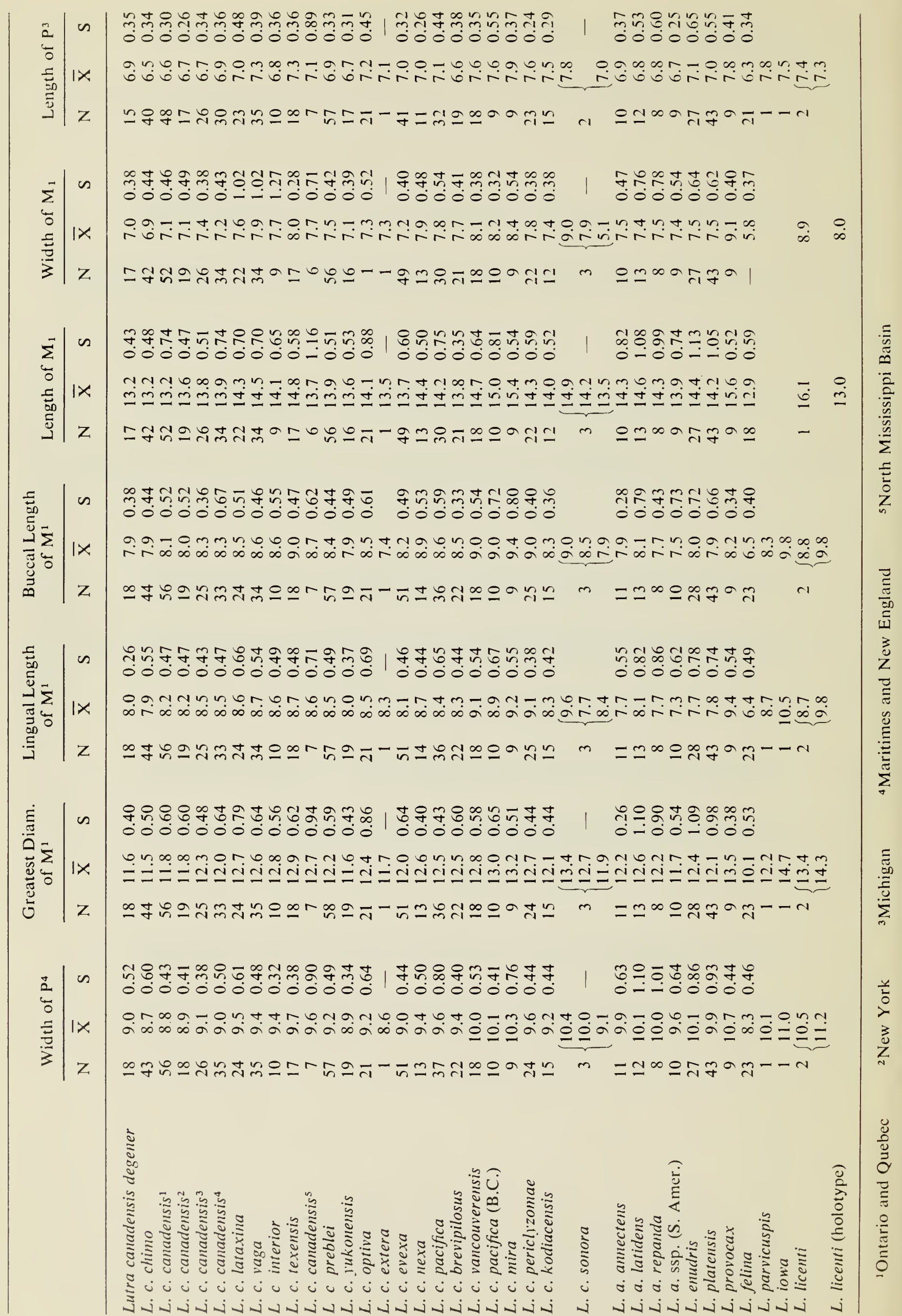




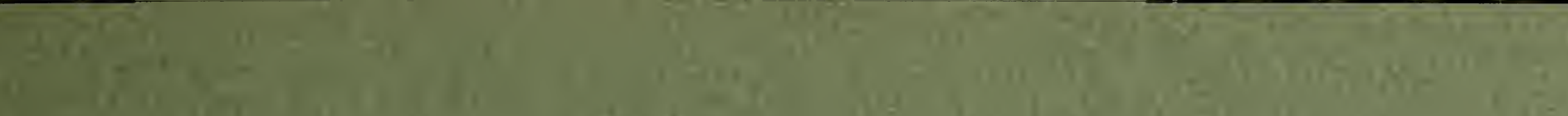

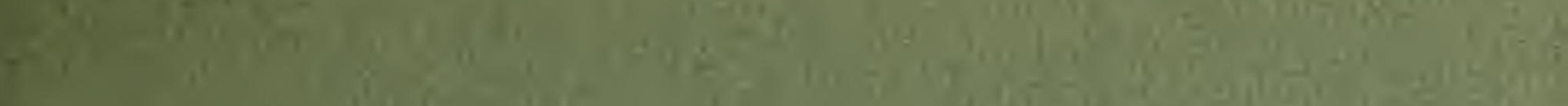

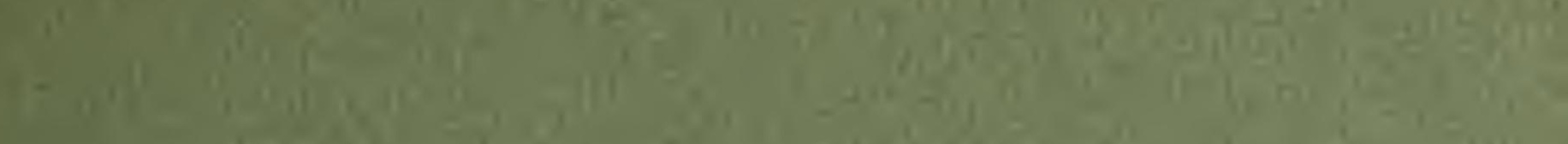
?.

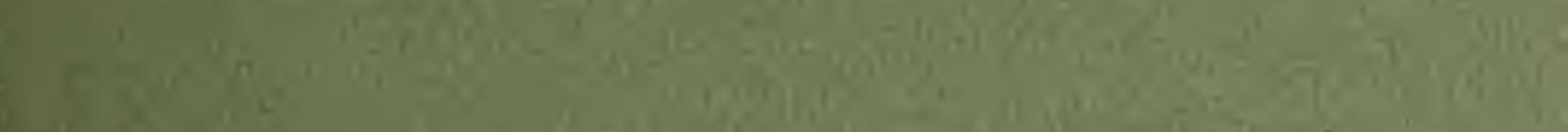

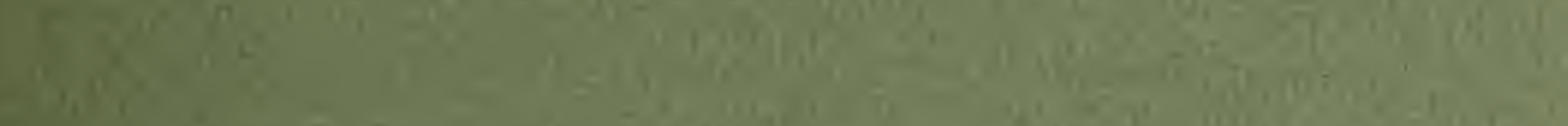

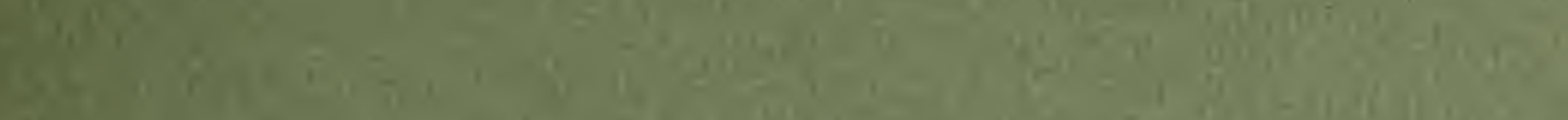

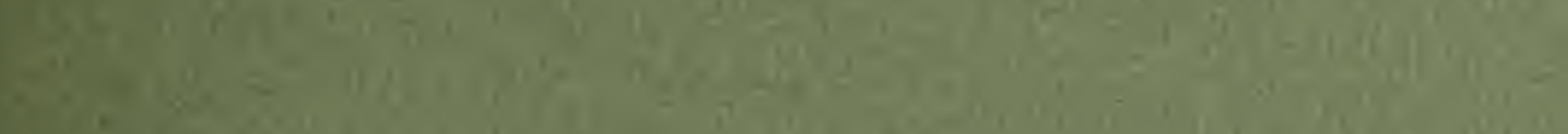

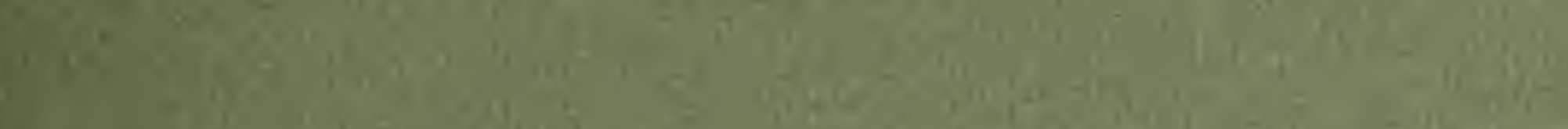

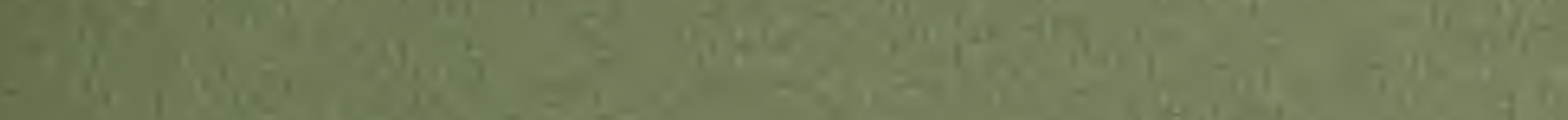

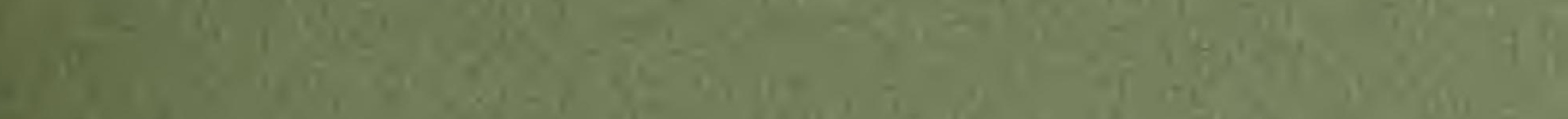

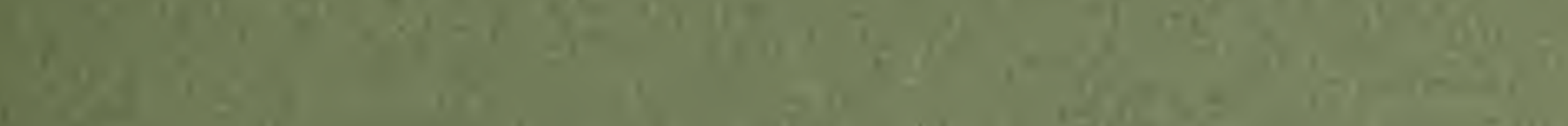

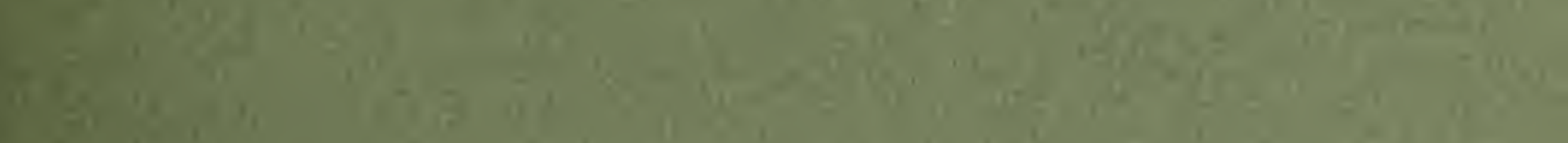

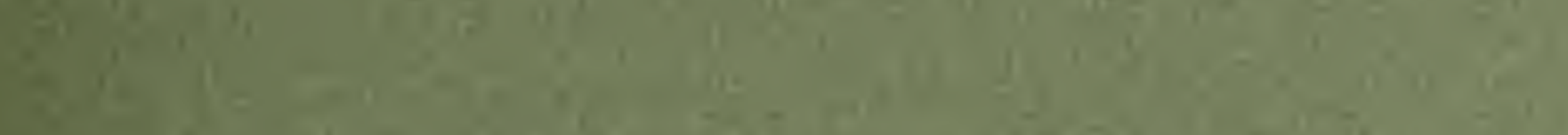

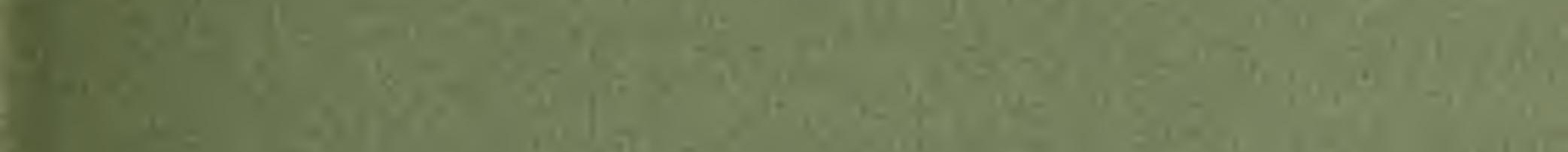

LII

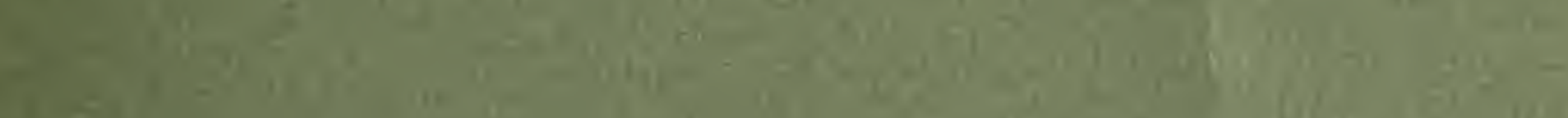

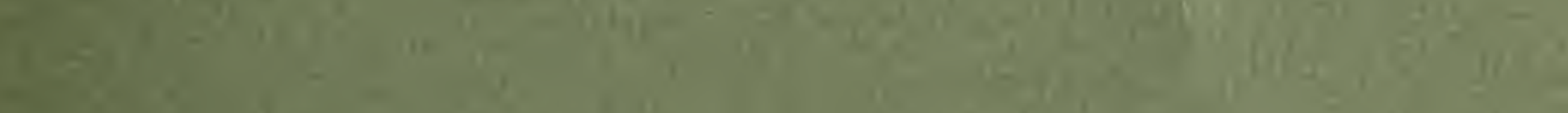

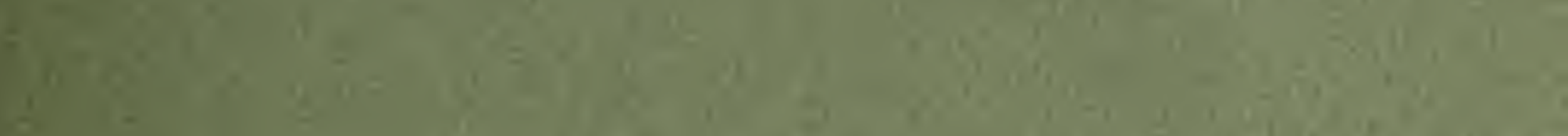

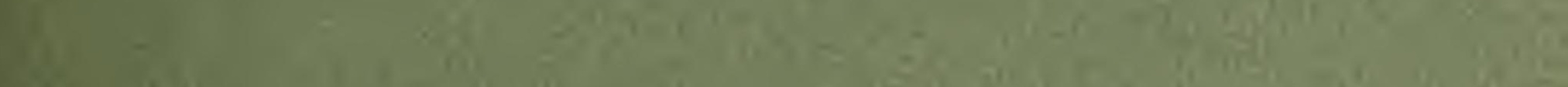
W. Ho

i.

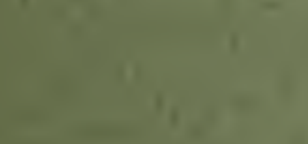

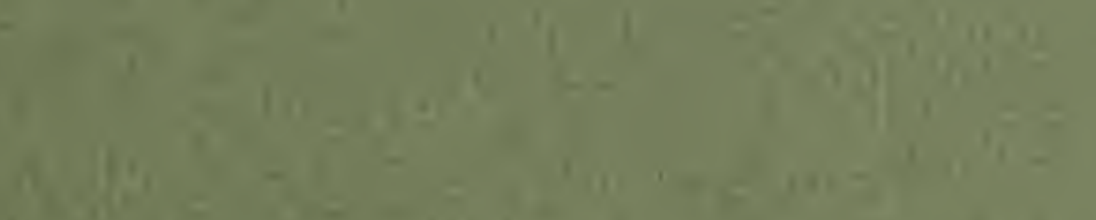

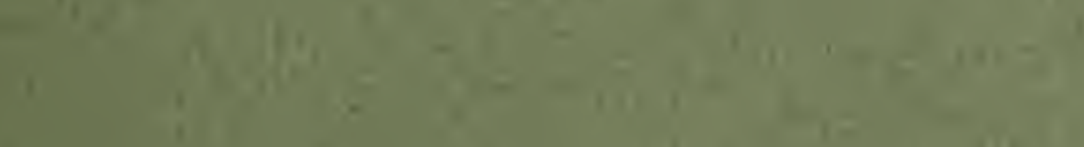

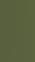

18

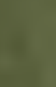

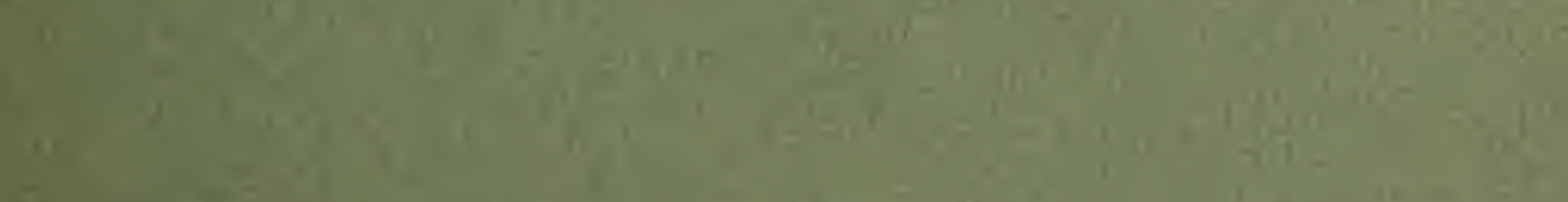

(1)

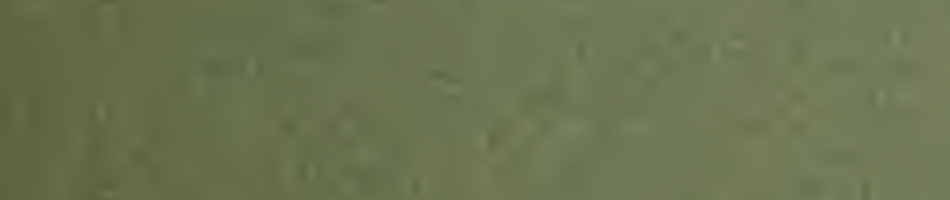

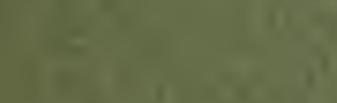

278 ind

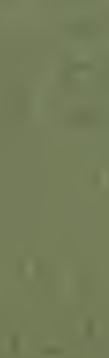


